\title{
Análise citogenética comparada em mastocitomas: enfoque especial na raça Boxer
}

Dissertação apresentada ao Programa de Pós-Graduação em Patologia Experimental e Comparada da Faculdade de Medicina Veterinária e Zootecnia da Universidade de São Paulo para obtenção do título de Mestre em Ciências

Departamento:

Patologia

Área de Concentração:

Patologia Experimental e comparada

Orientadora:

Profa. Dra Maria Lúcia Zaidan Dagli

São Paulo 
Autorizo a reprodução parcial ou total desta obra, para fins acadêmicos, desde que citada a fonte.

DADOS INTERNACIONAIS DE CATALOGAÇĀO-NA-PUBLICAÇÄO

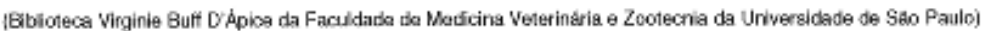

\begin{tabular}{|c|c|}
\hline \multirow[t]{5}{*}{$\begin{array}{l}\text { T.2111 } \\
\text { FMVZ }\end{array}$} & $\begin{array}{l}\text { Real-Lima, Mirela Aline } \\
\text { Análise citogenética comparada em mastocitomas: enfoque especial na } \\
\text { raça Boxer / Mirela Aline Real de Lima. - Săo Paulo : M. A. Real-Lima, } \\
2009 \text {. } \\
115 \text { f. : il. }\end{array}$ \\
\hline & $\begin{array}{l}\text { Dissertaçāo (mestrado) - Universidade de São Paulo. Faculdade de } \\
\text { Medicina Veterinária e Zootecnia. Departamento de Patologia, } 2009 .\end{array}$ \\
\hline & $\begin{array}{l}\text { Programa de Pós-Graduaçăo: Patologia Experimental e comparada. } \\
\text { Área de concentraçảo: Patologia Experimental e comparada. }\end{array}$ \\
\hline & Orientador: Profa. Dra. Maria Lúcia Zaidan Dagli. \\
\hline & $\begin{array}{l}\text { 1. Mastocitoma. 2. Boxer. 3. Citogenética. 4. Cromossomos. } \\
\text { 5. Alteraçöes cromossômicas. I. Tífulo. }\end{array}$ \\
\hline
\end{tabular}




\section{CERTIFICADO}

Certificamos que o Projeto intitulado "Análise citogenética comparada em mastocitomas: enfoque especial na raça Boxer", protocolado sob o n⿳1017/2008, utilizando 30 (trinta) cães, sob a responsabilidade da Profa. Dra. Maria Lúcia Zaidan Dagli, está de acordo com os princípios éticos de experimentação animal da Comissão de Bioética da Faculdade de Medicina Veterinária e Zootecnia da Universidade de São Paulo e foi aprovado na reunião do dia 23 de abril de 2008.

We certify that the Research "Comparative cytogenetic analysis in mastocytoma: special focus in boxer breed", utilizing 30 (thirty) dogs, protocol number 1317/2008, under the responsibility Profa. Dra. Maria Lúcia Zaidan Dagli, agree with Ethical Principles in Animal Research adopted by Bioethic Commission of the School of Veterinary Medicine and Animal Science of University of São Paulo and was approved in the meeting of day $04 / 23 / 08$.

São Paulo, 23 de abril de 2008

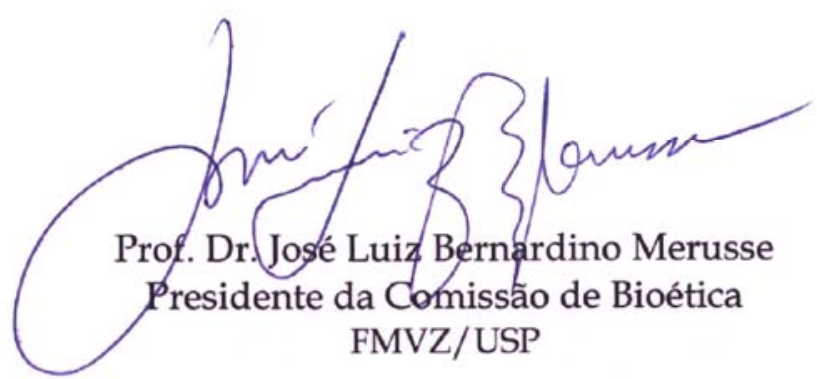


UNIVERSIDADE DE SÃO PAULO

FACULDADE DE MEDICINA VETERINÁRIA E ZOOTECNIA

HOSPITAL VETERINÁRIO

/jsc

À Ilustríssima Senhora

Professora Doutora Maria Lucia Zaidan Dagli

\section{DECLARAÇÃo}

Declaramos que o projeto "Análise citogenética comparada em mastocitomas: enfoque especial na raça Boxer", desenvolvido pela Pós-Graduanda Mirela Aline Real de Lima, sob a sua responsabilidade, previamente aprovado pela Comissão de Bioética desta Faculdade, foi analisado e atende às normas da Comissão de Ética desse Hospital, que acompanhará administrativamente sua execução. Substituição do responsável, inserção de novos colaboradores e mudanças na metodologia proposta deverão ser imediatamente comunicadas a esta Comissão, como as datas de suspensão ou término do projeto.

São Paulo, 27 de agosto de 2008.

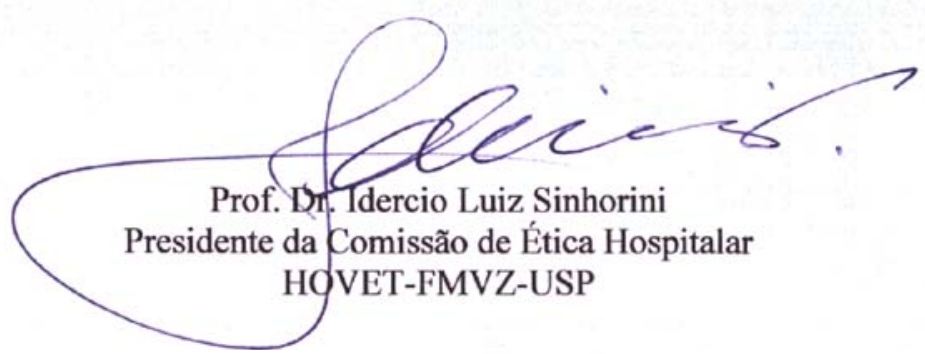

Av. Prof. Dr. Orlando Marques de Paiva, 87

Fone: $+55113091-1291 / 3091-1240$ 


\section{FOLHA DE AVALIAÇÃO}

Nome: Real-Lima, Mirela Aline

Título: Análise citogenética comparada em mastocitomas: enfoque especial na raça Boxer

Dissertação apresentada ao Programa de Pós- Graduação em Patologia Experimental e Comparada da Faculdade de Medicina Veterinária e Zootecnia da Universidade de São Paulo para obtenção do título de Mestre em Ciências

Data:

\section{Banca Examinadora}

Prof(a) Dr(a) Instituição

Assinatura: Julgamento

$\operatorname{Prof}(a) \operatorname{Dr}(a)$ Instituição

Assinatura: Julgamento

$\operatorname{Prof}(a) \operatorname{Dr}(a)$ Instituição

Assinatura: Julgamento 
À melhor família do mundo:

Meus pais e irmãos pelo apoio, Compreensão, carinho e amor infinitos. 
"De todos os animais que conhecemos é o cachorro o que mais se uniu a nós, Sejam príncipes que lhe dão farta comida e leito de plumas, ou mendigos que dormem ao relento e só podem oferecer-lhe uma pequena parte das suas próprias migalhas, idêntica é a sua afeição e dedicação, e com igual amor lambe a mão ornada de jóias e os dedos trêmulos, consumidos de doença e fome. "

Théo Gygas, em "O cão em Nossa Casa"

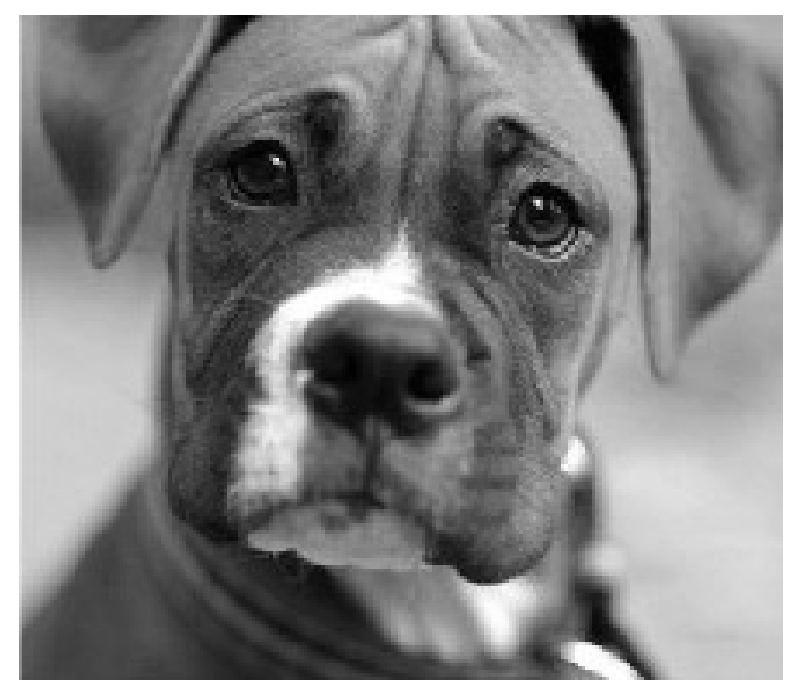




\section{AGRADECIMENTOS}

Primeiramente agradeço a Deus por me colocar num bom caminho $e$ por me ajudar a trilhá-lo.

À Professora Maria Lúcia Zaidan Dagli, por acreditar na menina que apareceu com uma vontade e realizou um sonho; também por confiar no trabalho de uma biomédica em meio à Medicina Veterinária e pela forma como trata todos os "filhos".

Agradeço infinitamente meus pais, Dolores e Manoel, por terem unido seus gametas em prol da genética, não propositalmente. Aos meus irmãos, Ygor e Marianne, pelos momentos de alegria, união $e$ consideração. Minha família teve grande importância na realização deste trabalho. Muito obrigada por permanecerem do meu lado e por acreditarem na minha capacidade. Amo muito vocês.

Ao Filipe, namorado, amigo e companheiro, e sua família, por todos os finais de semana de alegria, pescarias memoráveis e dedicação a mim. Obrigada por estarem sempre do meu lado.

Agradecimento especial ao meu primo Paulo, pela paciência e didática nos ensinamentos da informática e seus atalhos mágicos.

Às técnicas do laboratório, Marguiti e Cyntia, por todo respaldo científico, técnico e principalmente pela amizade. Pessoas incríveis, admiráveis e amáveis; hoje, amigas para o futuro. 
Aos colegas do Laboratório de Oncologia Experimental que se tornaram amigos. Por toda ajuda, ensinamentos, consideração, amizade, preocupação e por todos os momentos de alegria que pudemos compartilhar. Bruno, Lucas, Tereza, Patrícia, Márcia, Priscila, Juliana, Natália, Ivone, Luise, Marcelo, Daniel, Heidge, Zé, Gabriela, Heloisa, Kátia Pinello, Kátia Kimura, Fábia. Dentre as pessoas especiais, existem as mais especiais... Bru, Lucas e Tê, me refiro a vocês!

Agradeço aos funcionários do Departamento de Patologia, por toda ajuda, pela amizade e muitas vezes, pelos momentos de descontração que pudemos viver juntos.

Aos funcionários e amigos do HOVET, que muitas vezes fizeram mais do que thes cabia para me ajudar a realizar os experimentos. Thaís e Leda: não existem palavras para definir a força que vocês me deram.

A todos os funcionários da FMVZ que estiveram envolvidos direta e indiretamente na realização deste mestrado.

Aos amigos-anjos, do Instituto de Biociências do Departamento de Genética e Biologia Evolutiva, que me ensinaram muito do que eu sei sobre genética.

À Professora Yatiyo, que me acolheu e permitiu que eu conhecesse os anjos!

Agradeço imensamente ao Rodrigo, Renata e à Márcia, que hoje considero grandes amigos, pela companhia, ensinamentos, paciência, por todas as técnicas, protocolos e por todos os momentos de risadas e cafés juntos. Aos colegas da Bio, que fizeram dos meus momentos de trabalho mais felizes. 
A todas as pessoas que fizeram do meu mestrado uma das fases mais felizes da minha vida; a todas as pessoas que se preocuparam comigo e por todas as coisas que aprendi nessa fase.

Agradecimento especial aos cães que fizeram parte deste trabalho e aos seus donos, que autorizaram a utilização dos materiais.

Agradeço à FAPESP pelo suporte financeiro para a realização desta dissertação. 


\section{RESUMO}

REAL-LIMA, M. A. Análise citogenética comparada em mastocitomas: enfoque especial na raça Boxer. [Compared cytogenetic analysis in mast cell tumors: a special focus on Boxer breed.]. 2009. 115 f. Dissertação (Mestrado em Ciências) Faculdade de Medicina Veterinária e Zootecnia, Universidade de São Paulo, São Paulo, 2009.

Atualmente muitas são as técnicas utilizadas na área de citogenética para que os desequilíbrios genéticos potencialmente hereditários sejam identificados ou evitados. Algumas das técnicas são utilizadas apenas para o diagnóstico de enfermidades em humanos, mas seria importante que fossem aplicadas também aos animais domésticos, com a finalidade de se associar uma causa genética ao aparecimento de algumas doenças, como por exemplo, os mastocitomas. Os mastocitomas são formações cutâneas neoplásicas originadas de mastócitos e se apresentam com frequência em cães. Algumas raças apresentam maior susceptibilidade ao aparecimento de mastocitoma, e o Boxer tem a maior incidência nesta espécie. Este trabalho objetivou avaliar comparativamente o cariótipo de cães da raça Boxer e buscar uma possível correlação com o desenvolvimento de mastocitoma. Foram utilizadas técnicas citogenéticas de bandamentos $C, G$ e Ron além de análises em coloração convencional (Giemsa). Para tais análises utilizaram-se células cultivadas de linfócitos periféricos e de mastocitomas de Boxer. O material foi analisado e fotografado em microscópio de imersão da marca Zeiss $®$, em objetiva de 100x, com filtro verde, equipado com software de análise citogenética Ikaros $®$. Foram consideradas alterações numéricas e estruturais. Foram analisadas 828 metáfases mitóticas provenientes de linfócitos periféricos e células de mastocitomas. A análise das metáfases provenientes de cultura de células dos linfócitos periféricos não apresentou alterações estruturais e a análise numérica mostrou somente uma metáfase com $2 n=77$, dentre 476 metáfases analisadas. Na análise das metáfases de células tumorais, entre todas as colorações, observou-se que $70,9 \%$ apresentou $2 n=78, \quad 17,4 \%$ mostraram $2 n=77 ; 9,8 \% \quad 2 n=76$. Cinco metáfases $(1,3 \%)$ apresentaram $2 n=79$ e duas células apresentaram $2 n=75$. Todas essas alterações numéricas estão relacionadas com alterações estruturais do tipo fusão cêntrica. Os 
resultados obtidos mostram que devido ao crescimento descontrolado, as células tumorais promovem rearranjos na tentativa de controlar a divisão celular. Ainda, o aprimoramento das técnicas diagnósticas em citogenética promove o conhecimento da biologia tumoral do mastocitoma canino, e consequentemente, possibilita o desenvolvimento de novas estratégias terapêuticas.

Palavras-chave: Mastocitoma. Boxer. Citogenética. Cromossomos. Alterações cromossômicas. 
REAL-LIMA, M. A. Compared cytogenetic analysis in mast cell tumors: a special focus on Boxer breed. [Análise citogenética comparada em mastocitomas: enfoque especial na raça Boxer.]. 2009. 115 f. Dissertação (Mestrado em Ciências) Faculdade de Medicina Veterinária e Zootecnia, Universidade de São Paulo, São Paulo, 2009.

Nowadays there are many techniques applyed in cytogenetics in order to identify or avoid potentially hereditary genetic imbalance. Some of the techniques are used only to diagnose human diseases, but it would be important to apply them also to domestic animals, with the purpose of associating a genetic cause with the appearance of some diseases like, for example, mastocytomas. The mastocytomas are neoplasics cutaneous formation originated from mastocitos and frequently appears in dogs. Some breeds show higher susceptibity to the appearance of mastocytoma, and the boxer breed has shown the highest incidence. The objective of this study is to comparatively evaluate the boxer breed chariotype and search for a possible correlation with the mastocytoma development. There has been utilized cytogenetics "bandamentos" C,G e Ron as well as conventional (Giemsa) coloring analysis. For those analysis there has been utilized cultivated cells from peripheral lynphocites and boxer's mastocytomas. The material as been analyzed and photographed in a Zeiss immersion microscope, using a 100x objective with green filter, equipped with Ikaros cytogenetic analysis software. It has been considered numerical and structural alterations. There has been analyzed 828 mithotics metaphases from peripheral lynphocites and mastocytomas cells. The analysis of metaphases from the culture of peripheral lynphocites cells did not show structural alterations and the numerical analysis has shown only one metaphase $2 n=77$, among 476 analyzed metaphases. In the tumoral metaphase cells analysis, among all colorations, it has been observed that $70,9 \%$ presented $2 n=78,17,4 \%$ shown $2 n=77$ and $9,8 \% 2 n=76$. Five metaphases $(1,3 \%)$ presented $2 n=79$ and two cell presented $2 n=75$. All these numerical alterations are related with structural alterations from the centric fusion type. The obtained results shows that due to the uncontrolled growth, 
the tumoral cells promote rearrangements in an attempt to control a cellular division. Yet, the improvement of diagnosis technique in cytogenetics promotes the knowledge of canine mastocytoma tumoral biology, and consequently allows the new therapeutic strategy development.

Keywords: Mastocytoma. Boxer. Cytogenetics. Chromosomes. Chromosome alterations. 


\section{SUMÁRIO}

1 INTRODUÇÃO

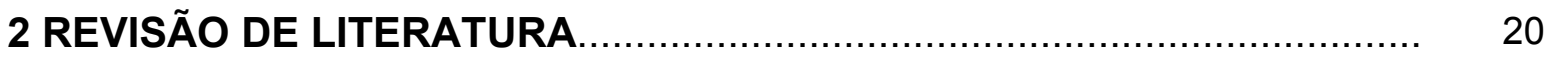

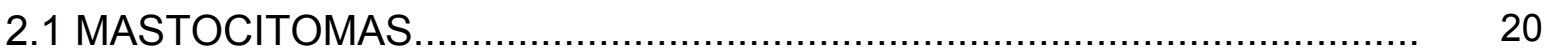

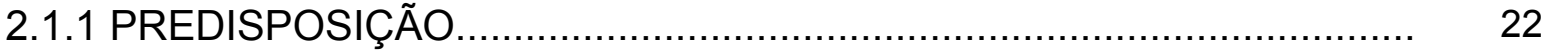

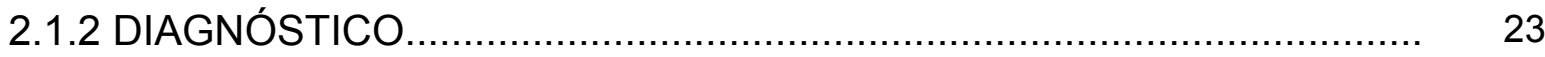

2.1.3 CLASSIFICAÇÃO HISTOPATOLÓGICA DO MASTOCITOMA.............. 24

2.1.4 SINAIS CLÍNICOS DO MASTOCITOMA............................................ 27

2.1.5 TRATAMENTO DOS MASTOCITOMAS............................................... 28

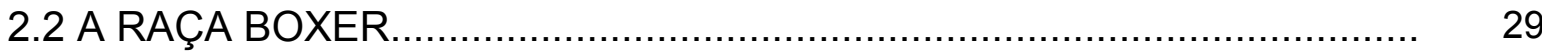

2.3 GENÉTICA E CÂNCER ..................................................................... 31

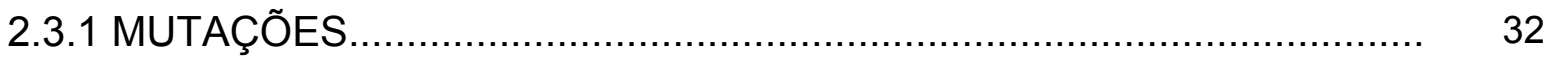

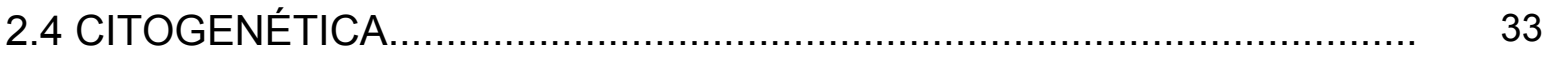

2.4.1 ASPECTOS HISTÓRICOS DA CITOGENÉTICA.................................. 34

2.4.2 OS CROMOSSOMOS E O DNA ......................................................

2.4.3 ESTRUTURA E TIPOS DE CROMOSSOMOS.................................... 38

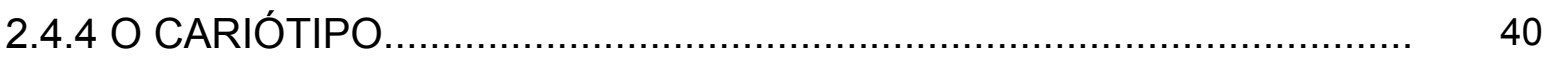

2.4.5 COLORAÇÕES E BANDAMENTOS....................................................

2.4.6 ALTERAÇÕES CROMOSSÔMICAS................................................... 42

2.4.6.1 ALTERAÇÕES NUMÉRICAS.......................................................... 42

2.4.6.2 ALTERAÇÕES ESTRUTURAIS ...................................................... 
2.4.6.3 OUTRAS ALTERAÇÕES CITOGENÉTICAS........................................ 47

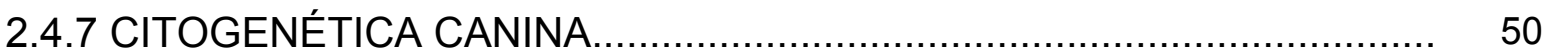

З OBJETIVOS

3.1 OBJETIVO GERAL............................................................... 54

3.2 OBJETIVOS ESPECÍFICOS .............................................................. 54

4 MATERIAI E MÉTODOS

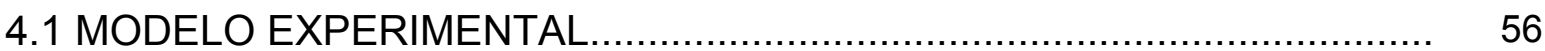

4.2 CLASSIFICAÇÃO DOS TUMORES....................................................... 58

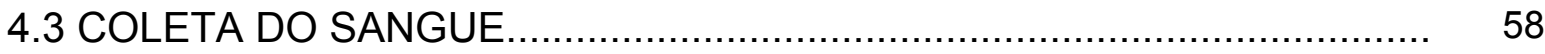

4.4 CULTURA CELULAR LEUCOCITÁRIA .................................................. 58

I OBTENÇÃO DOS CROMOSSOMOS EM METÁFASE (HSU e MOORHEAD, 1956, 59 modificado)

4.4.2 PREPARO DAS LÂMINAS PARA COLORAÇÃO.......................................... 60

4.5 CULTURA PRIMÁRIA DE MASTOCITOMAS (DEVINNEY e GOLD, 1990).......... 60

I PROCESSAMENTO PARA AQUISIÇÃO DOS CROMOSSOMOS EM 62 METÁFASE (Hsu e Moorhead, 1956, modificado)

4.5.2 PREPARO DAS LÂMINAS PARA COLORAÇÃO................................... 63

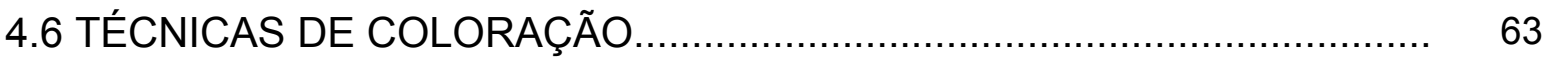

4.6.1 COLORAÇÃO CONVENCIONAL..................................................... 63

4.6.2 BANDA C (CBG), segundo Sumner (1972), com modificações............... 64

4.6.3 BANDA G (GTG), segundo Seabright (1971), com modificações........... 64

BANDA RON (REGIÕES ORGANIZADORAS DE NUCLÉOLOS), segundo 64 Howell e Black (1980), com modificações.

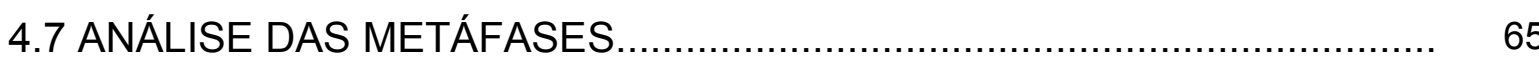




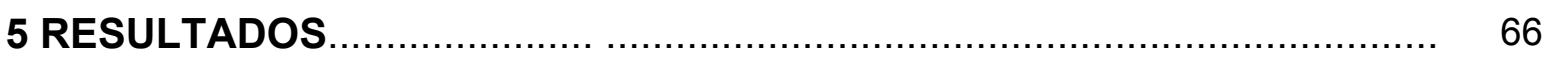

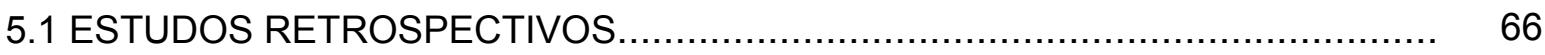

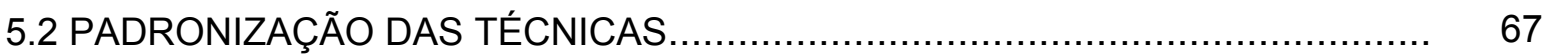

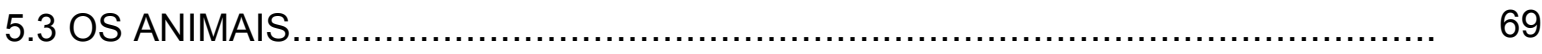

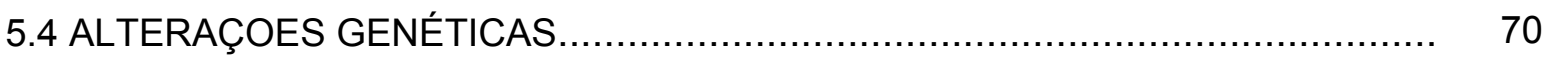

5.5 A RAÇA BOXER E AS ALTERAÇÕES CITOGENÉTICAS ............................... 70

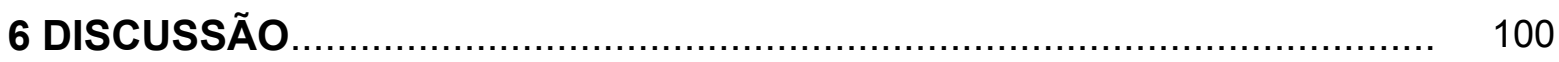

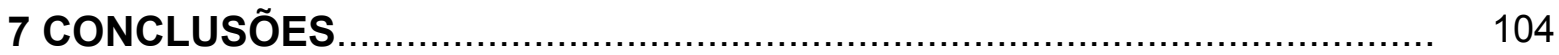

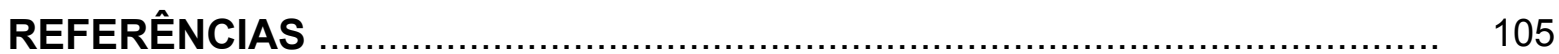




\section{INTRODUÇÃO}

É antiga a relação dos homens com pequenos animais domésticos, principalmente cães. Muitas raças caninas se desenvolveram a partir de cruzamentos entre animais de diferentes portes, e através desses cruzamentos resultaram raças com maior predisposição genética ao desenvolvimento de determinadas enfermidades.

A Raça Boxer tem origem alemã e foi desenvolvida no final do século XIX por um grupo de cinófilos alemães que procuravam obter, mediante o cruzamento de um tipo de cão antigo, conhecido como Bullenbeisser com o Buldogue Inglês, uma raça de características homogêneas e elegantes.

Os cães da raça Boxer são descritos como portadores de "defeitos" genéticos, frase justificada devido ao alto índice de desenvolvimento de moléstias, principalmente neoplasias.

Alguns tipos de tumores de pele e tecidos moles são freqüentemente encontrados em animais domésticos devido a uma série de características intrínsecas deste tecido. Além disso, os animais estão sujeitos a fatores genéticos e agentes internos envolvidos na produção de tumores (PULLEY; STANNARD, 1990) e a pele está exposta a uma variedade de fatores químicos e físicos (HUEPER, 1963). Uma neoplasia conhecida é o mastocitoma.

Os mastocitomas são formações cutâneas neoplásicas originadas de mastócitos com alterações genéticas (SELYE 1965; VAIL 1996; SOTER 2000) e compõem aproximadamente 7 a 20\% das neoplasias cutâneas nos cães (O'KEEFE, 2003). Essas formações se desenvolvem em muitos locais, mas são mais comumente encontradas na derme, no tecido subcutâneo e em mucosas (MISDORP, 2004).

Depois de diagnosticado o mastocitoma, o animal normalmente submetido ao procedimento cirúrgico para excisão da massa tumoral e posteriormente submetido 


\section{Introdução}

aos tratamentos disponíveis, como quimioterapia e radioterapia para que estabeleça uma boa qualidade de vida.

Atualmente existem técnicas avançadas, anteriormente somente utilizadas para tratamentos humanos, que estão sendo utilizadas como ferramentas para diagnóstico e tratamento de algumas enfermidades animais.

Uma das técnicas é a citogenética, que tem sido utilizada para elucidar enigmas até então não desvendados. A citogenética permite, a partir de uma pequena quantidade de células, uma análise complementar à análise histopatológica, por exemplo no caso de mastocitomas.

A análise citogenética permite conhecer uma alteração em nível cromossômico, desta maneira, é possível diagnosticar uma enfermidade e evitar que esta seja transmitida para as futuras gerações através do cruzamento dos animais afetados, o que evita a disseminação dessas alterações.

Trabalhos publicados destacam avanços nas descobertas de alterações cromossômicas envolvidas em neoplasias caninas com a utilização de técnicas citogenéticas, as quais possibilitam melhor análise de porções mais específicas dos cromossomos, (WINKLER et al., 2005).

Neste trabalho objetivamos analisar e descrever algumas alterações cromossômicas encontradas nas células provenientes de massa tumoral de mastocitomas, as quais possam estar associadas ao seu desenvolvimento.

Nas próximas páginas seguirão descritos comportamento tumoral e métodos citogenéticos, bem como um apanhado de literatura e aspectos históricos do que já se sabe sobre genética e citogenética canina, para servir de embasamento técnicocientífico para o leitor compreender os achados desta dissertação. 


\section{Revisão de Literatura}

As próximas páginas apresentarão um apanhado da literatura e aspectos históricos sobre os assuntos envolvidos neste trabalho, para que o leitor possa se familiarizar com o tema.

\subsection{MASTOCITOMAS}

Os mastocitomas são formações cutâneas neoplásicas originadas de mastócitos com alterações genéticas (SELYE 1965, VAIL 1996, SOTER 2000) e compõem aproximadamente sete a $20 \%$ das neoplasias cutâneas nos cães (O'KEEFE, 2003). Essas formações se desenvolvem em muitos locais, mas são mais comumente encontradas na derme, no tecido subcutâneo e em mucosas (MISDORP, 2004).

Os mastocitomas têm origem desconhecida, mas há correlação entre predisposição racial, inflamação crônica, ação viral no desenvolvimento da enfermidade (GRAHAM e O'KEEFE, 1998) e de mutações pontuais no gene "c-kit" em mastócitos neoplásicos de cães (REGUERA et al., 2000). A principal mutação encontrada foi uma duplicação que causa fosforilação constitutiva do receptor, sem a necessidade da ligação com Stem Cell Factor, "SCF". Isso explica o crescimento descontrolado dos tumores e a relação positiva das duplicações com a malignidade do mastocitoma (ZEMKE et al., 2002).

Há relatos de que locais que apresentam focos de inflamação crônica dão origem a mastocitomas, assim como especulações de que vírus possam exercer um papel no desenvolvimento dos mastocitomas (VAIL, 1996; GRAHAN e O'KEEFE, 1994). Essa hipótese é baseada em estudos experimentais nos quais cães desenvolveram mastocitomas após receberem injeções de extratos tumorais sem células (O`KEEFE, 2003). 


\section{Revisão de Literatura}

Os mastócitos constituem um componente normal do sistema imunológico e são importantes na resposta inflamatória a traumatismos teciduais. Os grânulos citoplasmáticos encontrados nos mastócitos contêm substâncias biologicamente ativas, tais como heparina, histamina, fator ativador de plaquetas e fator quimiotático eosinofílico (JANEWAY et al., 2002; METCALFE et al., 1997). Os mastócitos têm origem hematopoiética, migram para o tecido conjuntivo quando estão na forma madura e mantêm a capacidade de proliferar após a maturação (ZAPPULLA et al., 2002): os mastócitos caninos normais se assemelham aos mastócitos humanos (LAZARUS, 1986).

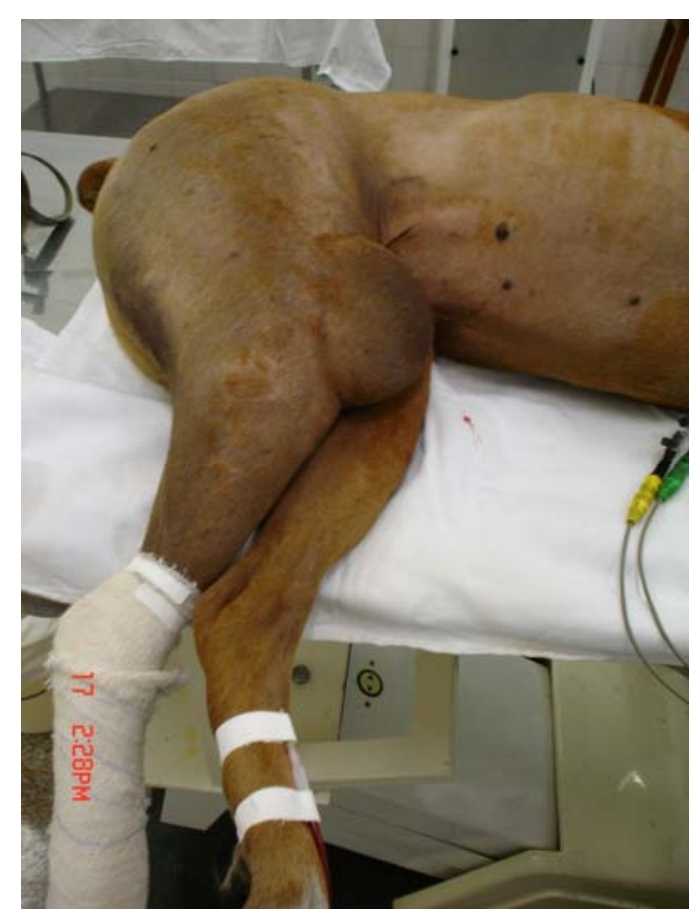

Figura 1 - Cão Boxer, macho, sete anos de idade, com mastocitoma grau II em membro posterior direito. Realizada excisão cirúrgica do tumor no Serviço de Cirurgia do Hospital Veterinário da FMVZ-USP. O animal apresentou intervalo de 12 meses para recidiva do tumor 


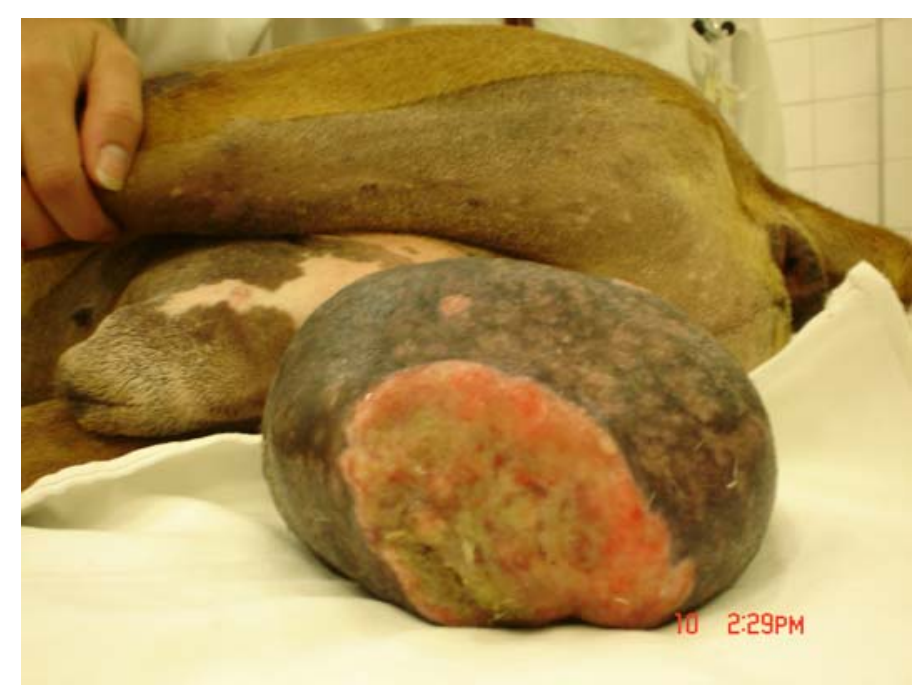

Figura 2 - Cão Boxer, macho, nove anos de idade, com mastocitoma metastático grau III em bolsa escrotal, linfonodo inguinal bilateral e linfonodo ilíaco esquerdo. Realizada excisão cirúrgica de escroto e linfonodos inguinais no Serviço de Cirurgia do Hospital Veterinário da FMVZ-USP. O animal foi submetido a quimioterapia no pós operatório e teve sobrevida de 4 meses após intervenção cirúrgica

\subsubsection{PREDISPOSIÇÃO}

A predisposição racial envolve, na grande maioria, cães sem raça definida, mas também acomete as raças Boxer, Boston Terrier, Buldogue Inglês, Bull Terrier Inglês, Beagle, Labrador e Schanauzer (VAIL 1996, O’KEEFE 2003). Ocorre principalmente em cães com idade média de 8-9 anos (VAIL, 1996).

Em geral, cães da raça Boxer apresentam grande susceptibilidade ao desenvolvimento de neoplasias, e tendo-se que os mastocitomas são as neoplasias mais incidentes em cães, essa enfermidade acomete mais especificamente os cães dessa raça. Nesses animais, os mastocitomas são geralmente bem-diferenciados e têm um prognóstico mais favorável (O’KEEFE, 2003). 
2.1.2 DIAGNÓSTICO

A citologia aspirativa por agulha fina é eficiente para se estabelecer 0 diagnóstico inicial de mastocitoma, mas o diagnóstico definitivo, relacionado diretamente ao prognóstico, é o exame histopatológico, fundamental para indicar a classificação do grau do tumor (MACY, 1986).

Os mastocitomas são classificados histomorfologicamente em três categorias (grau I, II e III), de acordo com o grau de diferenciação dos mastócitos presentes. Essa classificação é a mais utilizada e foi desenvolvida por PATNAIK et al. (1984).

O grau de diferenciação dos tumores está relacionado à quantidade e ao tipo de grânulos presentes no tecido, sendo que, os tumores bem-diferenciados contêm mais heparina do que os indiferenciados, que possuem um teor de histamina mais alto (LEMARIÉ et al., 1995). Com a liberação de histamina e estimulação dos receptores $\mathrm{H} 2$ do estômago, ocorre aumento de secreção do ácido clorídrico e aumento da motilidade gástrica, causando úlcera duodenal em $80 \%$ dos animais com mastocitoma (MADEWELL e THEILEN, 1987). As porcentagens observadas foram de $36 \%$ dos mastocitomas classificados como grau I, $43 \%$ grau II e $20 \%$ grau III (PATNAIK et al., 1984). 
2.1.3 CLASSIFICAÇÃO HISTOPATOLÓGICA DO MASTOCITOMA

Mastocitoma de grau I ou bem diferenciado (Figura 3): o tumor normalmente é pequeno, circunscrito à derme e não está encapsulado. A superfície da neoplasia muitas vezes não é ulcerada. As células neoplásicas se assemelham aos mastócitos normais e estão arranjadas em cordas e/ou camadas finas. O citoplasma é discreto com grânulos proeminentes que são tingidos de azul-acinzentado após se utilizar a coloração de hematoxilina-eosina. Mitoses são raras ou ausentes. Eosinófilos são encontrados em número significativo. Alguns tumores apresentam, ao redor de eosinófilos degenerados, pequenos focos de colagenólise (figuras de labareda); nessa condição é comum haver pouca quantidade de estroma dos feixes de colágeno e com variado edema; o núcleo é redondo ou ovalado; é pequeno, com o nucléolo quase imperceptível. Mitoses são infreqüentes ou ausentes. A hialinização perivascular é comum. A necrose tumoral é rara, mas áreas enfartadas podem aparecer.(GOLDSCHIMIDT e SHOFER, 1992; GROSS, IHRHE e WALDER, 1992). O mastocitoma de Grau I representa a maioria dos tumores em cães e normalmente apresenta comportamento benigno. (GROSS, IHRHE e WALDER, 1992; SCOTT, MILLER e GRIFFIN, 1996).

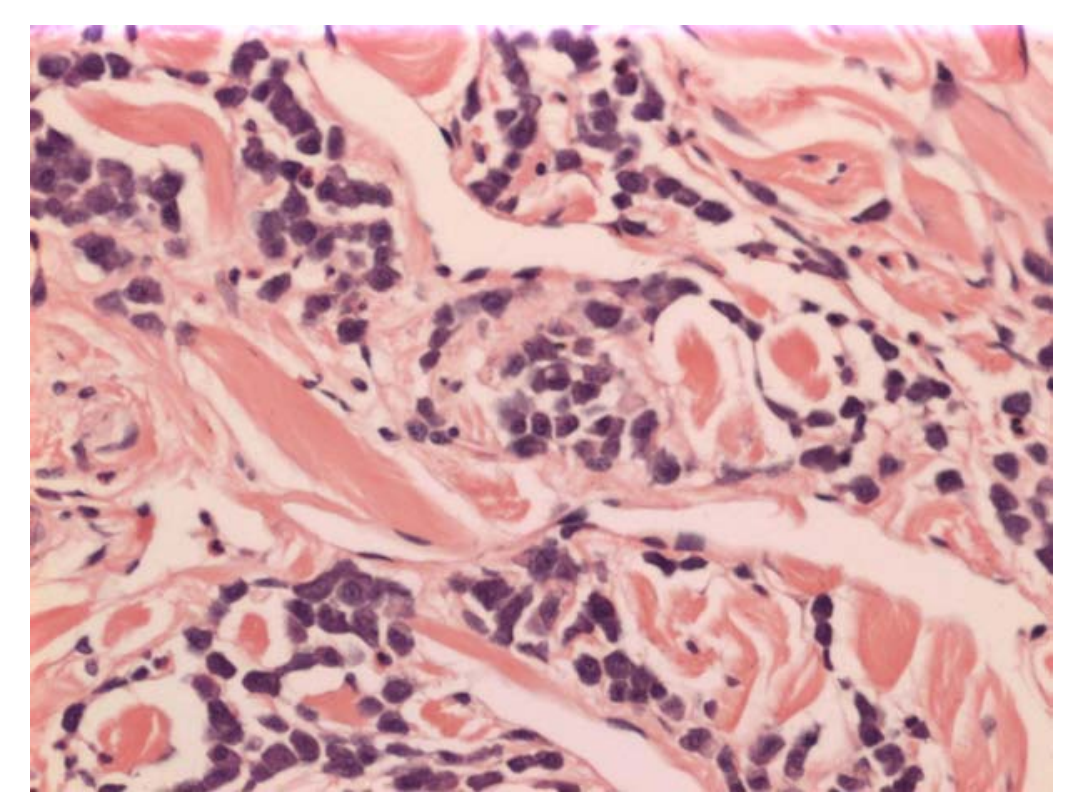

Figura 3: Histologia de mastocitoma grau I (200x, coloração HE). 
Mastocitoma de grau II ou moderadamente diferenciado (Figura 4): o tumor é maior e menos circunscrito que o anterior. Normalmente atinge a derme e o tecido subcutâneo. As células neoplásicas ainda estão arranjadas em cordas e lâminas, embora mais desorganizadas e com padrão infiltrativo de crescimento; são maiores, podem ser pleomórficas e têm menor quantidade de grânulos citoplasmáticos. Áreas de necrose e ulceração da superfície tumoral são comumente encontradas. O núcleo é maior que o de um mastócito normal e têm características pleomórficas; o nucléolo é pequeno, embora seja possível identificá-lo. A atividade mitótica é considerada baixa a média. A quantidade de estroma e de eosinófilos diminui. Poucas vezes são observados figuras de labareda.(GOLDSCHIMIDT e SHOFER, 1992; GROSS, IHRHE e WALDER, 1992). O mastocitoma de Grau II corresponde à cerca de $20 \%$ dos mastocitomas em cães.(GROSS, IHRHE e WALDER, 1992). O diagnóstico dos tumores mastocitários de grau I e II são normalmente claros e diretos. (GROSS, IHRHE e WALDER, 1992). O prognóstico também é mais favorável que o de Grau III, que é descrito a seguir:

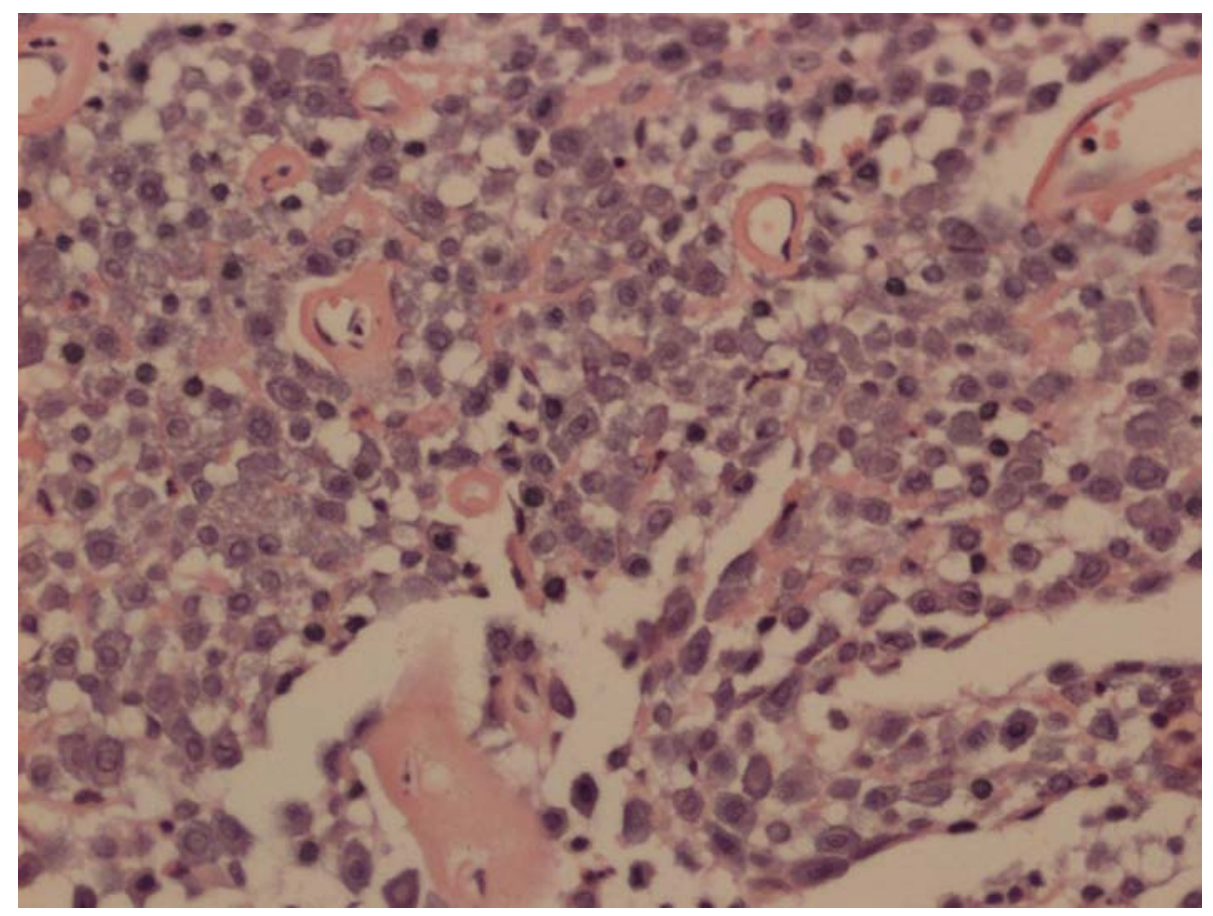

Figura 4: Histologia de mastocitoma grau II (200x, coloração HE). 


\section{Revisão de Literatura}

Mastocitoma de grau III ou pouco diferenciado (Figura 5): Normalmente, os tumores são grandes e ulcerados e ultrapassam o tecido subcutâneo. As células neoplásicas estão organizadas em camadas sólidas e os grânulos não são discerníveis sem as colorações especiais como a de Giemsa ou de azul de toluidina; são redondas, poligonais e bastante pleomórficas. A margem celular não é bem definida. O núcleo é grande, redondo a oval e vesicular; o nucléolo, muitas vezes,proeminente. A atividade mitótica varia de média a alta e são observadas diversas mitoses atípicas. Há pouca quantidade de eosinófilos e o estroma é escasso ou inexistente. (GOLDSCHIMIDT e SHOFER, 1992; GROSS, IHRHE e WALDER, 1992). Esse tipo de tumor é menos comum e a taxa de mortalidade, em decorrência das complicações sistêmicas, é alta. (GROSS, IHRHE e WALDER, 1992). A expressão do oncogene c-kit é maior em tumores de Grau III ou indiferenciados. (REGUERA et al.; ZEMKE, YAMINI e YUZBASIYAN-GURKAN, 2000).

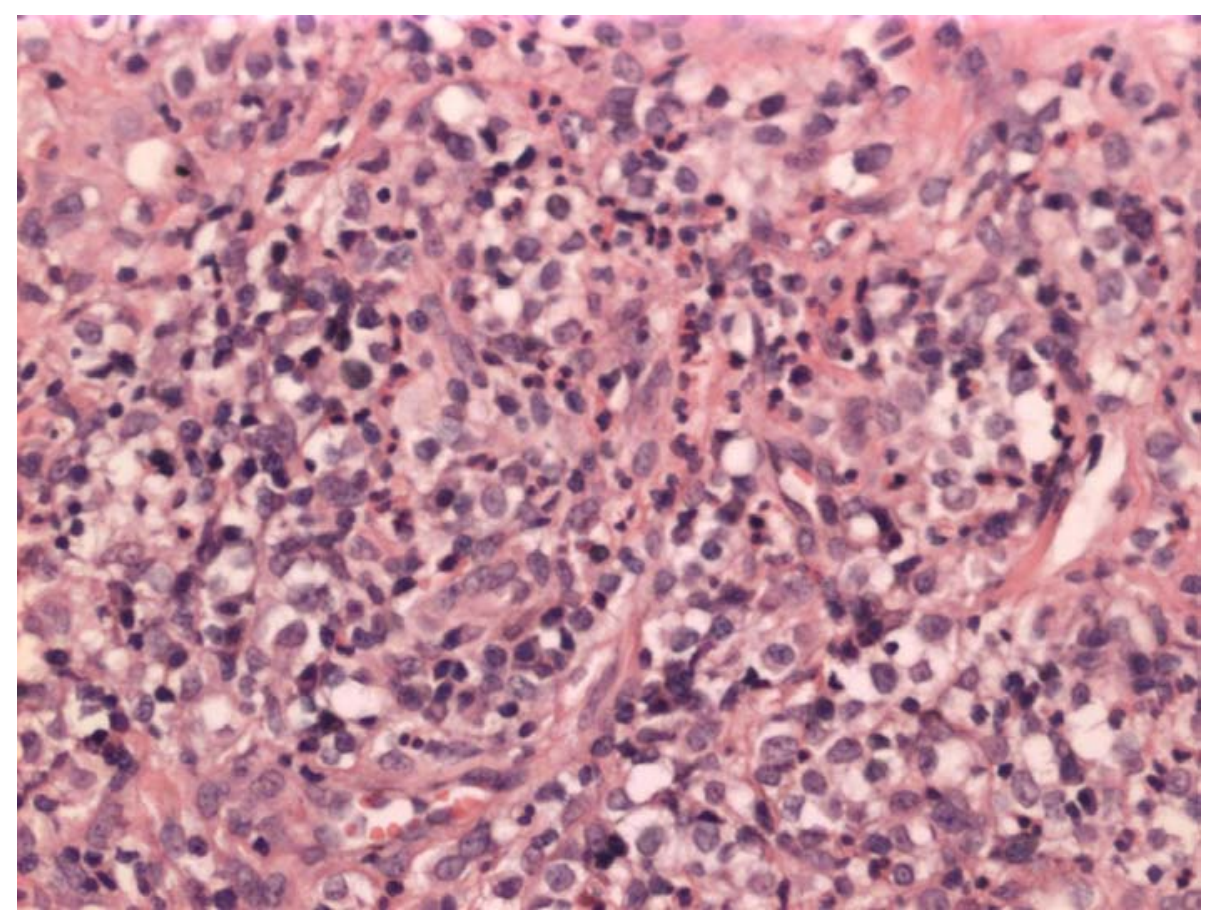

Figura 5: Histologia de mastocitoma grau III (200x, coloração HE). 
2.1.4 SINAIS CLÍNICOS DO MASTOCITOMA

Os sinais clínicos dos mastocitomas dependem da localização e do tamanho do tumor, bem como das complicações sistêmicas secundárias causadas pelo mastocitoma. Clinicamente são observados com mais frequência nódulos solitários e ulcerados na região do tronco e membros dos animais (MEDWELL E THEILEN, 1987).

Por outro lado, existe um grande acometimento de parte dos mastocitomas observados como massas solitárias na pele do tronco e da área perineal, com uma incidência de acometimento com cerca de 50\% dos casos, massas nas extremidades, como focinho e orelhas, em $40 \%$ e na cabeça e no pescoço, acometendo cerca de $10 \%$ dos animais (O'KEEFE, 2003).

Os mastocitomas dérmicos são geralmente massas salientes e bemdefinidas, que podem ficar sem os pelos sobre a região, ulceradas e eritematosas, e os mastocitomas subcutâneos podem lembrar lipomas (Graham e O'KEEFE, 1998).

Há relatos de úlceras duodenais em até $80 \%$ dos cães com mastocitomas e acredita-se que isso se relacione com a liberação de histamina, levando a possíveis sinais como anorexia, vômito, diarréia e melena (OGILVIE e MICHENER, 2000).

Os linfonodos regionais, baço e fígado constituem os locais de metástase mais comuns (MEDWELL e THEILEN, 1987). Há relatos de metástases observadas na medula óssea, o que sugere envolvimento sistêmico do tumor (Lemarié et al., 1995), sendo as metástases pulmonares menos frequentes (GRAHAM e O'KEEFE, 1998).

Os mastocitomas de baixa graduação apresentam menor probabilidade de recidivar ou metastatizar (O'BRIEN e WHITHRON, 1997), e os cães portadores destes tumores apresentam períodos de sobrevivência aumentados (O'KEEFE, 2003).

O comportamento biológico dos mastocitomas depende do estadiamento e diferenciação histológica dos tumores, idade e espécie acometida, e como é frequentemente difícil classificar o estadiamento dos tumores, deve-se considerar todos os mastocitomas potencialmente malignos, ocorrendo incidência de 
aproximadamente $50 \%$ dos mastocitomas assim classificados (GRAHAM e O`KEEFE, 1998).

O tempo de evolução e a velocidade de crescimento são fatores importantes que devem ser considerados para estabelecer o estadiamento e posterior tratamento e prognóstico, desse modo, o diagnóstico precoce dos tumores de crescimento lento está associado a um melhor prognóstico, mesmo com terapias mais simples (SIMÕES, 1994).

A localização e a velocidade de crescimento tumoral podem ajudar a prever o comportamento biológico, caracterizando os tumores das áreas prepucial, inguinal e perineal de tendência mais agressiva (O'KEEFE, 2003). Já os mastocitomas localizados numa área específica, como a mucosa intestinal, e de crescimento lento podem apresentar um prognóstico melhor (MEDWELL e THEILEN, 1987).

\subsubsection{TRATAMENTO DOS MASTOCITOMAS}

Uma vez classificado o tumor, o tratamento do mastocitoma pode incluir cirurgia, radioterapia, quimioterapia ou alguma combinação das três. O tipo de tratamento instituído depende primariamente do grau histológico e do estágio clínico do tumor, o qual permite a associação da cirurgia com radioterapia e/ou quimioterapia (GRAHAN e O'KEEFE, 1994).

Com manipulação cutânea, pode haver degranulação do mastocitoma, resultando em sinal de Darier, que se refere a uma área localizada de edema dérmico e eritema (MURPHY et al., 2005). A liberação de heparina e enzimas proteolíticas por parte dos mastocitomas no momento de uma cirurgia pode prolongar o tempo de coagulação e retardar a cicatrização do ferimento (JANEWAY, 2002).

Embora pareça ser uma massa discreta, os mastocitomas, geralmente se infiltram profundamente no interior dos tecidos circundantes, tornando obrigatória uma excisão cirúrgica abrangente (O'BRIEN e WHITHRON, 1997). A instituição de terapia de suporte, antes, durante e depois da cirurgia é imprescindível (KITCHELL, 
1993), deste modo, as chances de recidiva diminuem e o animal não é submetido ao tratamento novamente.

\subsection{A RAÇA BOXER}

A Raça Boxer tem origem alemã e foi desenvolvida no final do século XIX por um grupo de cinófilos alemães que procuravam obter, mediante o cruzamento de um tipo de cão antigo, conhecido como Bullenbeisser com o Buldogue Inglês, uma raça de características homogêneas e elegantes.

Perto de 1890, um cão com as características do atual Boxer se apresentou em Munich, cidade alemã da região da Bavária e acasalou com um antigo bulldog. Desse cruzamento, resultaram cães de queixo desenvolvido, orelhas altas e ossos fortes.

Derivou-se consequentes cruzamentos destes exemplares a fim de eliminarse os excessos de cor branca, proveniente do bulldog, e com isso, obtiveram-se a coloração desejada: o louro ou dourado. Além disto, principalmente, reduzir a robustez e conformação pesada, buscando uma conformação mais ágil e elegante.

Passados mais de cem anos para o aperfeiçoamento da raça, o que vemos hoje é um cão harmonioso, elegante e potente. Compacto e de figura quadrada, sua ossatura é pesada e sua pelagem curta. De musculatura plástica é poderosamente desenvolvida e nitidamente definida, o que confere um aspecto atlético e nobre.

De estatura média para grande, os machos devem medir em torno de $60 \mathrm{~cm}$, sendo que os machos com mais de $60 \mathrm{~cm}$, devem pesar mais de 30 quilos. As fêmeas (Figura 6), um pouco menores, medem cerca de $55 \mathrm{~cm}$ e aquelas que medirem mais de $56 \mathrm{~cm}$, devem pesar mais de 25 quilos.

Os cães da raça Boxer são descritos como portadores de problemas genéticos pelo alto índice de desenvolvimento de doenças, principalmente neoplasias. 


\section{Revisão de Literatura}

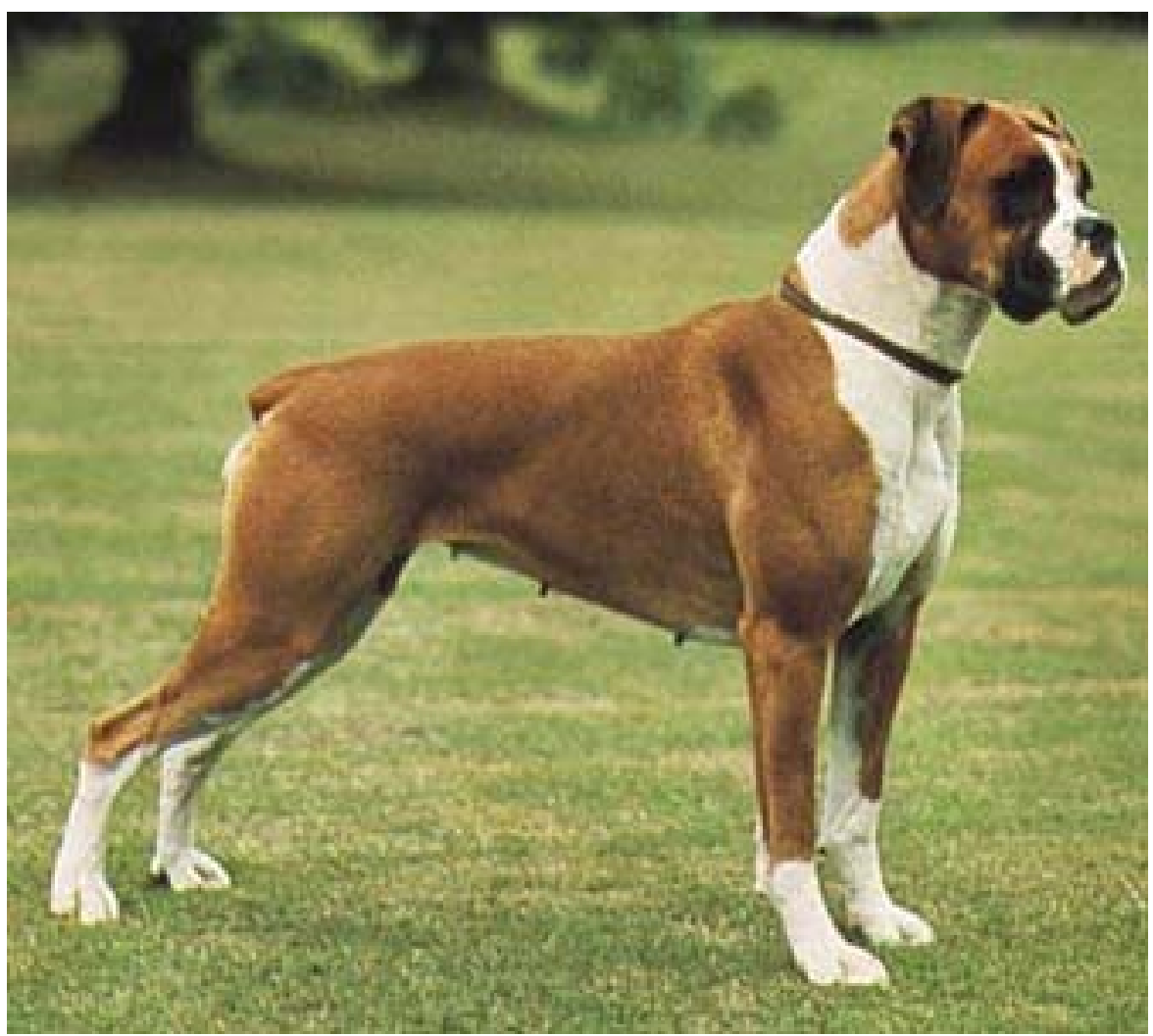

Figura 6: Cão fêmea da raça Boxer. 


\subsection{GENÉTICA E CÂNCER}

A transformação de uma célula normal em uma célula neoplásica é chamada de carcinogênese, caracterizada como um processo que envolve pelo menos três etapas: iniciação, promoção e progressão (FABER, 1984).

A fase de iniciação caracteriza-se por um dano irreversível no DNA que pode ser provocado por agentes químicos, físicos (radiação ultravioleta e ionizante), biológicos (vírus) ou genéticos (hereditariedade) (COTRAN; KUMAR; ROBBINS, 1989).

$\mathrm{Na}$ fase de promoção, observa-se a expansão pelo crescimento das células fenotipicamente alteradas por um estímulo a proliferação celular que pode ser decorrente da liberação de um fator de crescimento. (FABER; SARMA, 1987).

A fase de progressão caracteriza-se pela irreversibilidade que as alterações genéticas conferem às células, como o alto potencial proliferativo, a capacidade invasiva, a capacidade metastática e as alterações bioquímicas (PITOT; DRAGAN, 1991).

Câncer não é o resultado de um único evento dentro da célula. Uma série de eventos deve ocorrer para que o câncer possa se desenvolver. Uma única célula pode sofrer um evento de iniciação, mas a progênie desta célula deve ser submetida a novas alterações genéticas para que ocorra o desenvolvimento de células malignas. (SOLOMON et al., 1991).

Em diversos casos, estas alterações genéticas são mutações minúsculas em genes individuais. Em outros casos, as alterações genéticas são resultantes de alterações em larga escala na estrutura dos próprios cromossomos (ARMITAGE et al., 1954).

Há três categorias de genes que estão envolvidos na carcinogênese: os proto-oncogenes (promotores do crescimento), os anti-oncogenes (supressores tumorais) e os genes reguladores de apoptose (COTRAN; KUMAR; ROBBINS, 1989). 
Os proto-oncogenes codificam proteínas que necessitam de estímulos externos e ficam sujeitos a reguladores. Quando os proto-oncogenes são alterados de maneira a originarem células neoplásicas são chamados de oncogenes.

Os oncogenes codificam oncoproteínas que se assemelham aos produtos dos proto-oncogenes, porém são destituídas de elementos reguladores e sua produção nas células transformadas não depende de fatores de crescimento ou outros sinais externos. Os oncogenes podem estar presentes em todas as etapas da proliferação celular. (FABER; SARMA, 1987).

Os genes reguladores de apoptose regulam a morte celular através do controle das vias oxidativas. Por perpetuar a vida das células, a hiperexpressão de genes reguladores de apoptose promove o surgimento de mutações que afetam os genes promotores do crescimento e os anti-oncogenes (COTRAN; KUMAR; ROBBINS, 1989) .

\subsubsection{MUTAÇÕES}

As mutações não ocorrem tão raramente quanto parece. A freqüência delas é relativamente grande, porém, como são geralmente deletérias, os mecanismos de reparo do DNA evitam que grande parte das mutações se estabeleça. (SOLOMON et al., 1991)

As mutações são produzidas, entre outros eventos, por agentes mutagênicos, que interferem na autoduplicação do DNA ou na transcrição do RNAm, determinando erros nas seqüências dos nucleotídeos. Os agentes mutagênicos são fatores que podem elevar a freqüência das mutações. Substâncias químicas, como o "gás mostarda" e o ácido nitroso $\left(\mathrm{HNO}_{2}\right)$, aerossóis, corantes alimentares e alguns componentes da fumaça do cigarro também podem aumentar a freqüência de mutações, alterando o patrimônio genético de uma célula e podendo levar ao desenvolvimento de diferentes formas de cânceres. 


\section{Revisão de Literatura}

Tautomerismo de base são pareamentos errôneos no arranjo do DNA. Ao invés de haver o pareamento adenina-timina (A-T) e guanina-citosina ( $G-C)$, pode ocorrer adenina-citosina (A-C) e timina-guanina ( $T-G)$.

Radiação ionizante: na maioria dos estudos, a freqüência de mutações de ponto é diretamente proporcional à dose de irradiação (raios $\mathrm{X}$, raios gama e raios cósmicos).

A radiação ultravioleta é absorvida pelas purinas e pirimidinas, formando hidratos de pirimidinas e dímeros de pirimidinas (dimerização da timina - onde duas timinas próximas, de uma mesma fita de DNA, ligam-se, prejudicando o ajuste da dupla fita).

Acridinas são compostos que se intercalam entre a dupla fita, causando a inserção ou deleção de um ou mais pares de bases. Há alteração no módulo de leitura do DNA.

As alquilas transferem grupos metil ou etil para os sítios reativos das bases e dos fosfatos da cadeia de DNA. Um exemplo conhecido e bem estudado de mutação envolve a molécula de hemoglobina, que é uma proteína complexa constituída de quatro cadeias da proteína globina, combinadas com o complemento férrico heme.

Todos os seres vivos estão submetidos, diariamente, a vários desses agentes. A relativa estabilidade do material genético deve-se à existência de um grupo de enzimas de reparação, que "patrulham" permanentemente as moléculas de DNA à caça de alterações na seqüência de seus nucleotídeos. Na maioria das vezes, essas alterações são detectadas e reparadas. Existem vários mecanismos de reparo, como a excisão de nucleotídeos, onde uma enzima cliva e remove a região onde houve a mutação. $O$ vazio resultante é preenchido posteriormente, de forma correta, pela ação da enzima DNA-polimerase, que usa a cadeia de DNA como molde para proceder ao reparo. 


\subsection{CITOGENÉTICA}

A citogenética compreende todo e qualquer estudo relativo ao cromossomo, isolado ou em conjunto, condensado ou distendido, tanto no que diz respeito a sua morfologia, organização, função e replicação quanto a sua variação e evolução (GUERRA et al., 1988).

A análise do cariótipo ou estudo citogenético pode ser feita a partir de qualquer tecido celular, desde que coletado de forma adequada. Os tecidos comumente utilizados, seja pela facilidade de acesso ou pela especificidade, são sangue periférico, medula óssea, pele, tumores sólidos e tecidos fetais.

\subsubsection{ASPECTOS HISTÓRICOS DA CITOGENÉTICA}

As primeiras idéias sobre cromossomos surgiram no fim do século XIX, quando os primeiros estudos sobre mitose foram realizados. Em 1866, Haeckel propôs que o núcleo celular era o principal agente responsável pela divisão das células. Entretanto, o primeiro cientista a descrever o processo da divisão celular mitótica de forma clara foi o zoólogo alemão Anton Schneider, em 1873.

Posteriormente, outros pesquisadores ampliaram os estudos sobre mitose. Contribuições importantes foram dadas por Strasburger, em 1875 e por Flemming, de 1879-1882, este último o responsável pelo termo "mitose" (processo de divisão celular, do grego mitos = filamento). A partir disso, a divisão mitótica foi melhor compreendida em animais e vegetais.

Embora os estudos com cromossomos tenham se tornado frequentes, a idéia de que estavam envolvidos com herança genética somente surgiu em 1887, nos trabalhos de Weismann, que os introduziu na teoria de herança. Esta incluía os seguintes pontos:

1. "substância nuclear" controla a forma e a função de cada célula, e se divide (mitose) gerando produtos iguais a si. 
2. Ovos precisam perder metade da sua "substância nuclear" no corpúsculo polar antes da fertilização, e precisam ser completados com exatamente a mesma quantidade de "substância nuclear" proveniente do espermatozóide.

3. Pelo fato de a reprodução sexuada depender da junção dos núcleos do ovo e do espermatozóide em cada geração, é preciso que a "substância nuclear" das células germinativas de ambos tenha sido reduzida à metade. (Esta proposição foi formulada depois do entendimento do processo da meiose).

4. Não há diferenças substanciais na "substância nuclear" de células de ovos e espermatozóides.

5. A reprodução sexuada pode ser entendida como produtora de variabilidade entre os indivíduos, onde a seleção natural pode atuar.

A Teoria de Weismann considera todos estes pontos (passíveis de observação na natureza), mesmo tendo sido formulada com total ignorância das leis de Mendel. Estas foram redescobertas apenas em 1900, por três cientistas: Correns, de Vries e Tschermak, em uma série de estudos de citologia. Com o renascimento das leis de Mendel, surgiu a Teoria da herança cromossômica, que relaciona os cromossomos com as leis mendelianas de herança.

Este foi um marco para o estudo dos cromossomos e, no começo do século $\mathrm{XX}$, a citologia e a genética passaram a integrar os seus conhecimentos numa área comum, mais tarde denominada Citogenética.

\subsubsection{OS CROMOSSOMOS E O DNA}

Cromossomos (Kroma $=$ cor, soma $=$ corpo) são filamentos espiralados de cromatina, existentes no núcleo das células, compostos por uma longa seqüência de DNA e proteínas. O DNA contém vários genes, e diversas outras sequências de nucleotídeos com funções específicas nas células dos seres vivos. Cada cromossomo é uma molécula de DNA. 
O primeiro investigador a observar os cromossomos foi Karl Wilhelm Von Nägeli, em 1842, e o seu comportamento foi descrito em detalhe por Walther Flemming em 1882. Em 1910, Thomas Hunt Morgan provou que os cromossomos são os portadores dos genes.

Para análise cariotípica de mamíferos, os cromossomos metafásicos mitóticos são os mais adequados, devido, principalmente, ao seu alto grau de condensação, o que facilita a contagem do número diplóide, definição de morfologia e identificação dos cromossomos (GUERRA e SOUZA, 2002).

Mitose é o processo de divisão celular que distribui igualmente os cromossomos e constituintes citoplasmáticos da célula mãe entre duas células filhas. Tal processo é responsável pela multiplicação dos organismos unicelulares e pelo crescimento dos pluricelulares, por aumentar o número de células.

A mitose divide-se em quatro etapas: prófase, metáfase, anáfase e telófase. É justamente no estágio de metáfase que os cromossomos são melhor observados devido à sua maior concentração e individualização. São utilizadas substâncias antimitóticas para que a mitose seja interrompida na metáfase. Tais substâncias ligamse às proteínas que formam as fibras do fuso acromático (tubulinas), impedindo sua polimerização e consequentemente suprimindo a formação das fibras, ou ainda inativando os fusos já formados. A substância antimitótica mais comumente utilizada é a colchicina.

Na composição química da cromatina constam proteínas, DNA e RNA (este último em menor quantidade). As proteínas são de duas classes: as proteínas básicas, chamadas histonas; e as proteínas ácidas, chamadas de proteínas cromossômicas não-histônicas.

As histonas desempenham um importante papel na estruturação do cromossomo. Tanto que sua proporção no núcleo é de 1:1 (peso/peso) em relação ao próprio DNA. 
A estrutura da cromatina dos eucariotos é composta de subunidades repetidas chamadas nucleossomos. Estes consistem de um segmento de DNA de 146 pares de nucleotídeos de comprimento, enrolado em torno da superfície um tanto cilíndrica do octâmero de histonas, produzindo uma estrutura aproximadamente elipsóide.

Pelo menos cinco níveis de condensação são necessários para empacotar o DNA(a) no cromossomo de eucariotos em uma estrutura metafásica de poucos micros de comprimento, como indicado a seguir na figura 7 .

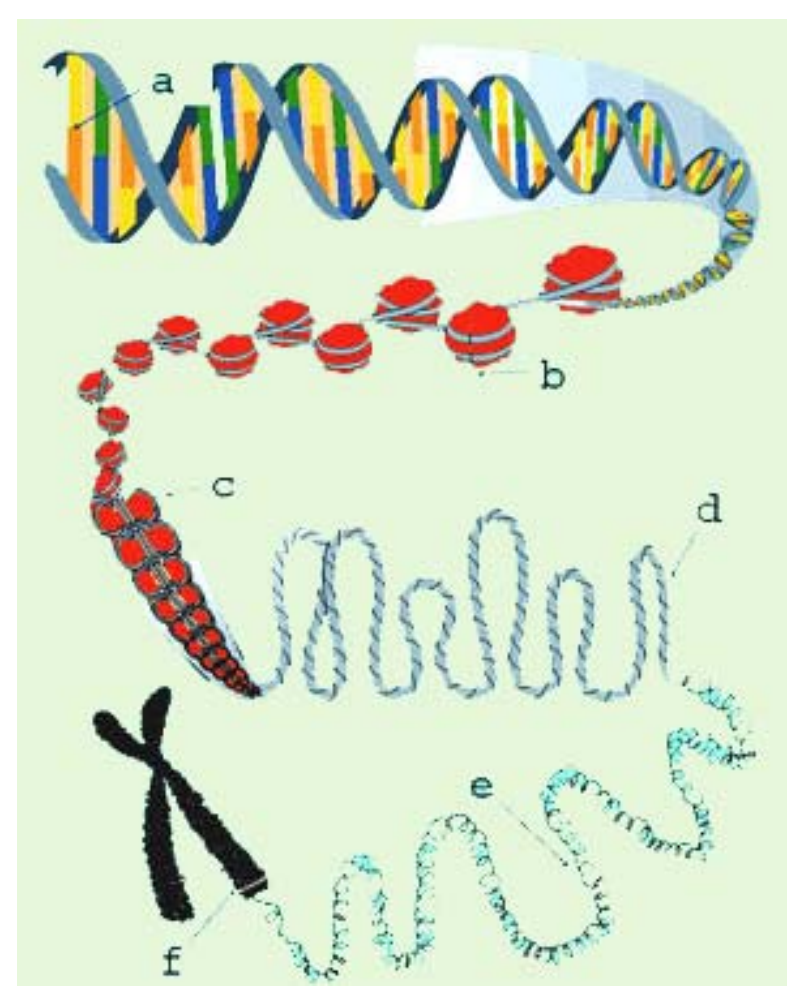

Figura 7: llustração dos níveis de condensação do DNA.

1. O primeiro envolve o empacotamento do DNA como uma espiral em nucleossomos de aproximadamente $10 \mathrm{~nm}$ de diâmetro. Este passo envolve um octâmero de histonas (b).

2. O segundo envolve a estrutura de solenóide, um segundo nível de epiralamento, produzindo uma fibra de $30 \mathrm{~nm}$ (c). 
3. O terceiro são os "loops" de solenóides, ligados a um esqueleto central protéico. Esta estrutura tem aproximadamente $300 \mathrm{~nm}$ de diâmetro (d).

4. O quarto são "loops" do esqueleto protéico, formando uma estrutura gigante, super enrolada, com 700nm (e).

5. Por fim, na sua máxima condensação, a cromátide cromossômica conta com cerca de 1400nm de diâmetro (f).

\subsubsection{ESTRUTURA E TIPOS DE CROMOSSOMOS}

O cromossomo metafásico típico é formado por duas cromátides irmãs, uma delas oriunda do processo de duplicação da cromatina. As cromátides se encontram presas por uma região delgada, chamada constrição primária ou centrômero.

O centrômero divide a cromátide em dois braços cromossômicos. Ou pode estar localizado na região terminal de um braço, formando um cromossomo com um braço apenas.

Ainda pode ser visualizada em alguns cromossomos uma constrição secundária, outra região de condensação diferenciada. O segmento seccionado pela constrição secundária e anterior ao telômero (extremidade dos braços cromossômicos) é conhecido como satélite.

A maioria dos cromossomos são monocêntricos, ou seja, possuem um centrômero apenas. Na natureza podem ser encontrados cromossomos dicêntricos, tricêntricos, acêntricos, etc. A estrutura de um cromossomo está exemplificada na figura 8. 


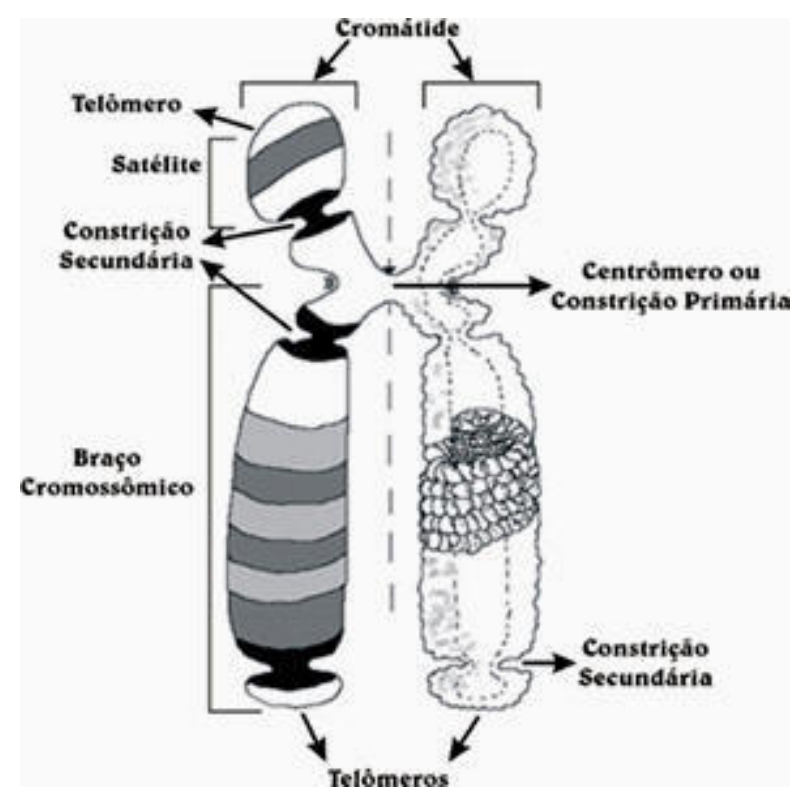

Figura 8: Ilustração esquemática da estrutura de um cromossomo.

As classificações dos tipos cromossômicos (Figura 9) são feitas com base na localização dos centrômeros. Um exemplo é a classificação de Levan et al. (1964), que considera quatro tipos cromossômicos em relação à razão de braços. A razão é calculada dividindo-se a medida do maior braço (q) pela do menor braço $(p)$.

Razão de braços dos cromossomos:

Metacêntrico RB = 1,00 - 1,70

Submetacêntrico RB $=1,71-3,00$

Subtelocêntrico RB $=3,01-7,00$

Acrocêntrico RB > 7,01 


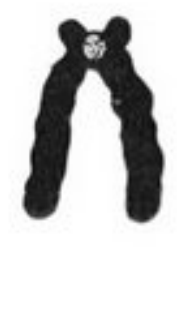

A

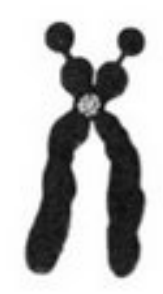

B

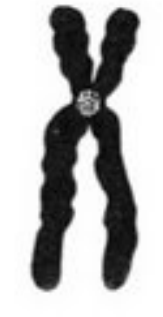

C

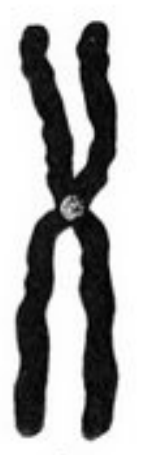

D

Figura 9: Ilustração esquemática dos tipos de cromossomos pela classificação de Levan et al. (1964): (A) Cromossomo acrocêntrico; (B) Cromossomo subtelocêntrico; (C) Cromossomo submetacêntrico; (D) Cromossomo metacêntrico.

As constrições secundárias também são regiões particulares dos cromossomos. Nelas geralmente estão as regiões organizadoras de nucléolo (RONs). Nas RONs estão localizados os genes responsáveis pela produção de rRNAs, os quais constituem parte do nucléolo. A sua importância está em justamente produzir e processar os RNAs necessários para sintetizar todas as proteínas da célula. Os genes ribossômicos estão presentes em múltiplas cópias no genoma, ou seja, é um tipo de DNA repetitivo.

\subsubsection{O CARIÓTIPO}

A partir da forma e do número de cromossomos de uma espécie, é estabelecido seu cariótipo. O Cariótipo é a representação do conjunto de cromossomos presentes em uma célula, ordenados em pares de homólogos. A palavra cariótipo (karyotype em inglês) é derivada da palavra grega "karyon" (nó) e "typos" (forma). 
A representação do cariótipo pode ser um cariograma (imagem dos cromossomos) ou um idiograma (esquema dos cromossomos), e fornece as informações substanciais para o estabelecimento das relações entre espécies, com respeito à organização dos cromossomos.

\subsubsection{COLORAÇÕES E BANDAMENTOS}

Além das colorações ditas como convencionais (Giemsa, Orceína Acética, reativo de Schiff, hematoxilina/eosina, etc.), podem ser aplicadas nos cromossomos metodologias que identificam "bandas".

Uma banda é definida como parte do cromossomo na qual é claramente distinta do segmento adjacente, apresentando-se mais claro ou escuro. Os cromossomos são visualizados como uma série contínua de bandas claras e escuras.

Os bandamentos (C, G, Q, R, Ag-RON) são importantes para a identificação de cromossomos homólogos e homeólogos, na caracterização de polimorfismos e até mesmo identificando relações de parentesco entre espécies próximas, distinguindo possíveis rearranjos cromossômicos.

Bandas $G$ são as mais comumente usadas. Essa nomenclatura provém do corante utilizado Giemsa, mas pode ser produzido com outros corantes. Nas bandas $G$, as regiões escuras tendem a serem heterocromatinas (contêm muitas repetições), são de replicação tardia e ricas em adenina e timina. As regiões claras tendem a serem eucromatinas (regiões ativas em transcrição), com replicação precoce e ricas em guanina e citosina.

$O$ método de bandamento $C$ permite a visualização das regiões ricas em heterocromatina constitutiva, como os centrômeros de alguns cromossomos, evidenciando, ricas em guanina e citosina.

Através do protocolo de coloração pela prata, é possível observar as Regiões Organizadoras do Nucléolo (Rons), onde encontram-se os loci dos genes para RNA 


\section{Revisão de Literatura}

ribossômico (RNAr). As Rons apenas apresentam afinidade pela prata quando transcricionalmente ativas.

\subsubsection{ALTERAÇÕES CROMOSSÔMICAS}

Cada espécie tem um número específico de cromossomos. Devido à ocorrência de irregularidades durante a divisão nuclear, podem ocorrer células ou organismos inteiros com genomas aberrantes. Tais alterações cromossômicas podem incluir genomas inteiros, cromossomos isolados inteiros ou apenas partes de cromossomos. Assim, as alterações cromossômicas podem ser numéricas ou estruturais, e envolverem um ou mais autossomo, cromossomo sexual ou ambos. Toda alteração tem efeito importante sobre o desenvolvimento, pois a alteração do núcleo normal pode resultar em alteração fenotípica.

\subsubsection{ALTERAÇÕES NUMÉRICAS}

As aberrações cromossômicas numéricas (heteroploidias) incluem os casos em que há aumento ou diminuição do número de cromossomos do cariótipo habitual. As variações que atingem conjuntos inteiros de cromossomos são definidas como euploidias e as que resultam em perda ou adição de cromossomos inteiros isolados são as aneuploidias.

As euploidias são alterações cromossômicas numéricas caracterizadas pela presença de todo um conjunto haplóide a mais, além do número diplóide básico de cromossomos. As alterações podem gerar indivíduos com características haplóides (n), diplóides (2n), triplóides (3n), tetraplóides (4n), enfim, poliplóides (quando há vários genomas em excesso). 
A aneuploidia refere-se à situação em que o número de cromossomos não é um múltiplo exato do número haplóide característico da espécie. Esta anomalia deve-se a não separação (ou não-segregação) de um ou mais cromossomos para as células-filhas durante o processo de divisão celular. A não-segregação na mitose decorre do não-rompimento do centrômero no inícioda anáfase ou da perda de algum cromossomo por não ter se ligado ao fuso.Quando em conseqüência desse processo de não-segregação falta um cromossomo de um dado par, isto é, quando o número de cromossomos da célula é $2 n-1$, diz-se que a célula apresenta monossomia para este cromossomo. Caso haja falta de dois elementos do mesmo par $(2 n-2)$, tem-se nulisomia. Se pelo contrário, houver aumento do número de cromossomos de um determinado par, a célula será polissômica para o cromossomo em questão; ela será trissômica, tetrassômica, pentassômica etc., conforme tiver 1, 2 ou 3 cromossomos a mais, sendo, nesses casos, o seu número cromossômico designado por $(2 n+1),(2 n+2),(2 n+3)$ etc.

\subsubsection{ALTERAÇÕES ESTRUTURAIS}

As alterações cromossômicas estruturais incluem os casos em que um ou mais cromossomos apresentam alterações que afetam a estrutura molecular do DNA.

Geralmente as mudanças estruturais requerem quebras nos cromossomos, podendo ocorrer em diversos pontos em um cromossomo ou no conjunto todo. Uma extremidade quebrada pode se unir com qualquer outra extremidade quebrada, ocorrendo arranjos novos entre estes cromossomos.

Os processos que determinam as modificações estruturais no genoma do indivíduo podem ser seis tipos básicos: deleção, duplicação, inversão, translocação, transposição e fissão/fusão cêntricas. 
A deleção ocorre por perda de fragmentos do cromossomo, que podem excluir um ou muitos genes e podem se originar por simples quebra ou eliminação cromossômica (Figura 10).

A duplicação ocorre quando um segmento cromossômico aparece mais de duas vezes em uma célula diplóide normal. O segmento pode estar ligado a um cromossomo ou como um fragmento separado. Por intermédio da segregação destes cromossomos nos gametas, as duplicações podem ser transmitidas às gerações subseqüentes (Figura 11).

A inversão acontece quando parte do cromossomo se destaca (por quebra cromossômica), giram $180^{\circ}$ e são re-inseridas de modo que os genes fiquem em ordem inversa. Algumas inversões resultam do embaraçamento dos filamentos durante a prófase meiótica. As inversões podem incluir o centrômero (inversões pericêntricas) ou não incluir o centrômero (inversões paracêntricas) (Figura 12).

A translocação ocorre quando parte de um cromossomo se separa e se liga a uma parte de um cromossomo não homólogo. Este tipo de alteração pode ser de dois tipos: 1) Simples, quando o fragmento quebrado de um cromossomo se insere em outro não homólogo, ou 2) Recíproca, quando os segmentos são trocados entre dois cromossomos não homólogos (Figura 13).

A transposição refere-se à troca de segmentos de um local do cromossomo para outro. Geralmente não há grandes alterações, pois o conteúdo genômico não é alterado, porém o pareamento pode ser difícil durante a divisão celular (Figura 14).

Fusão e fissão cêntricas são modificações onde o número cromossômico pode aumentar ou diminuir sem que haja variação na quantidade de DNA. Isso ocorre devido à quebra do cromossomo na altura do centrômero, dando origem a dois cromossomos acrocêntricos (fissão), ou ao processo inverso (fusão) (Figura 15). 


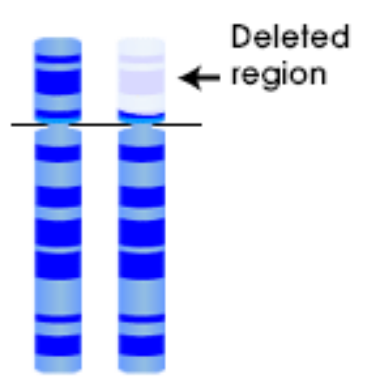

Figura 10 - llustração de processo de deleção

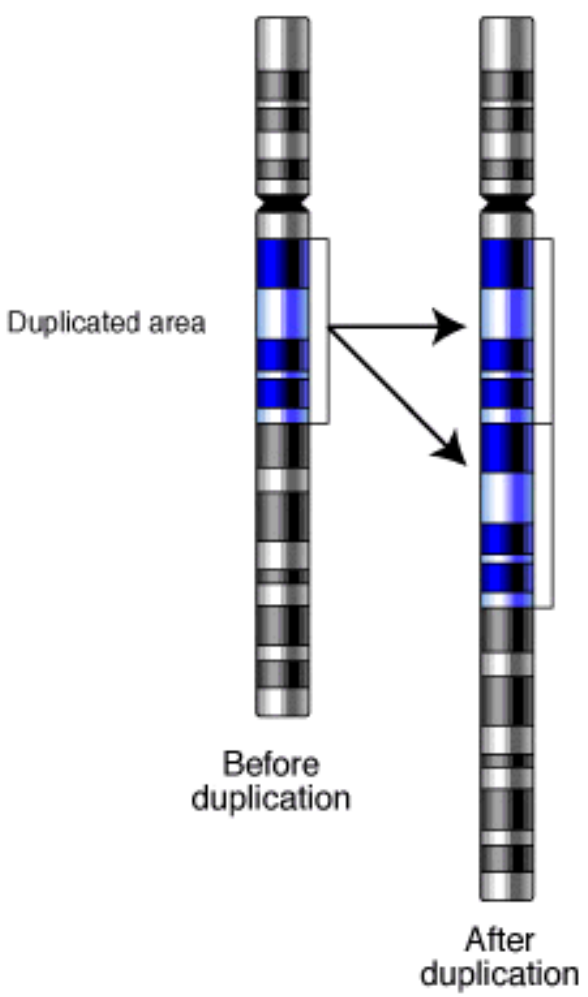

Figura 11 - Ilustração de processo de duplicação 


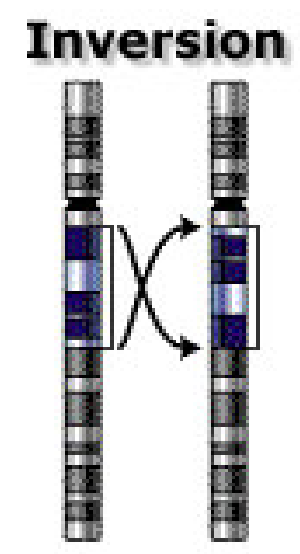

Figura 12 - llustração de processo de inversão

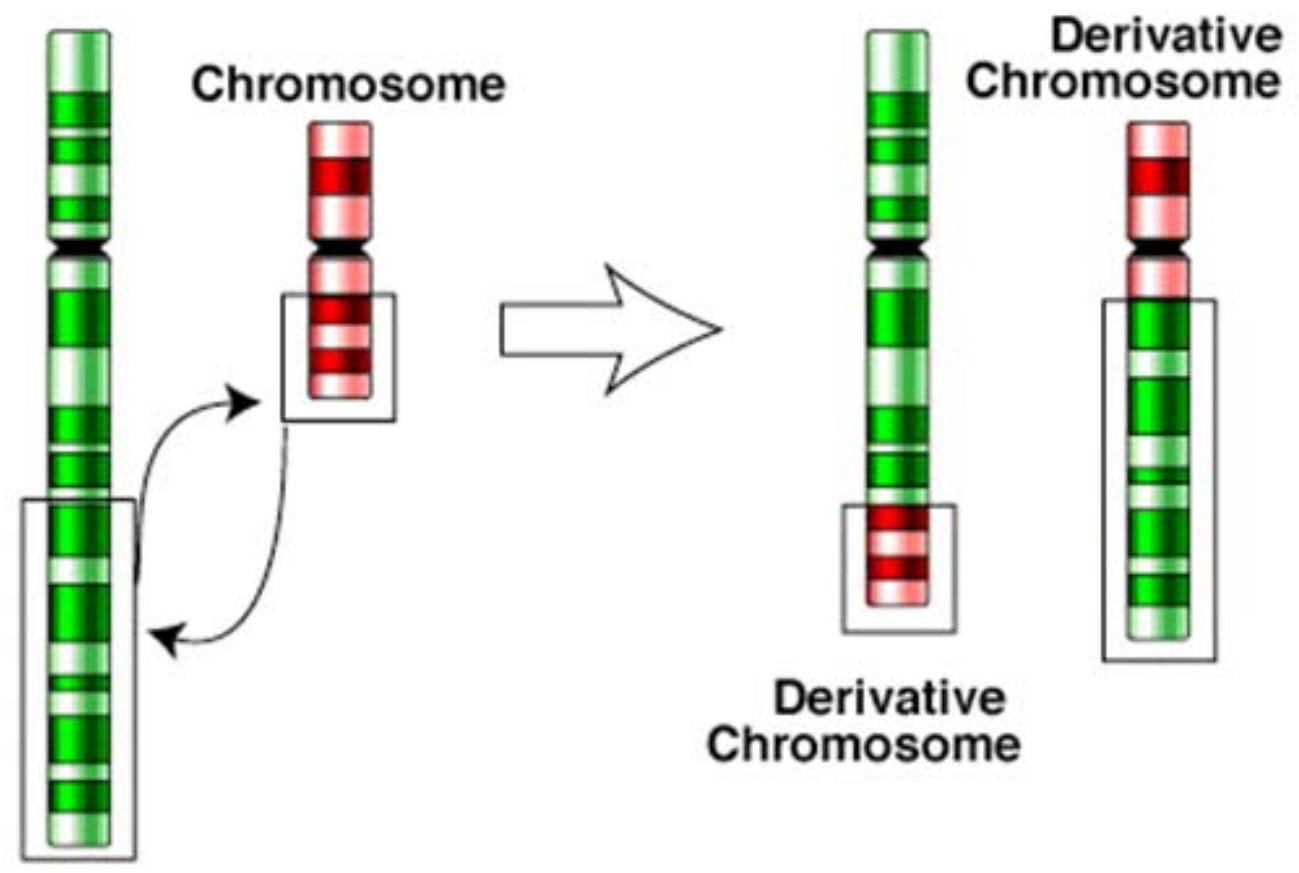

Figura 13 - Ilustração de processo de translocação 


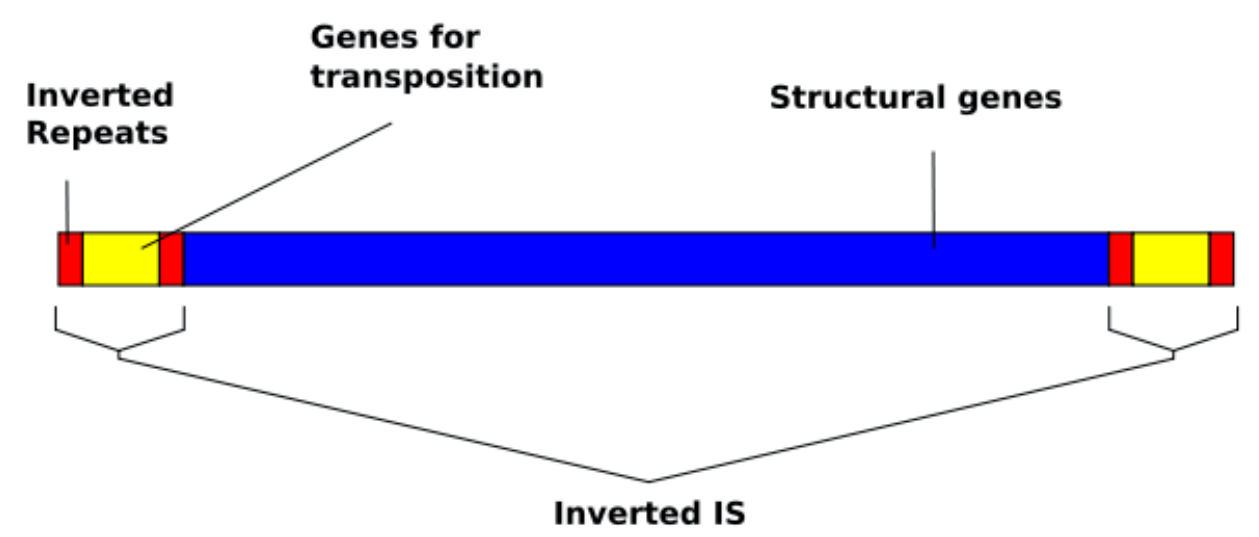

Figura 14 - llustração de processo de deleção transposição
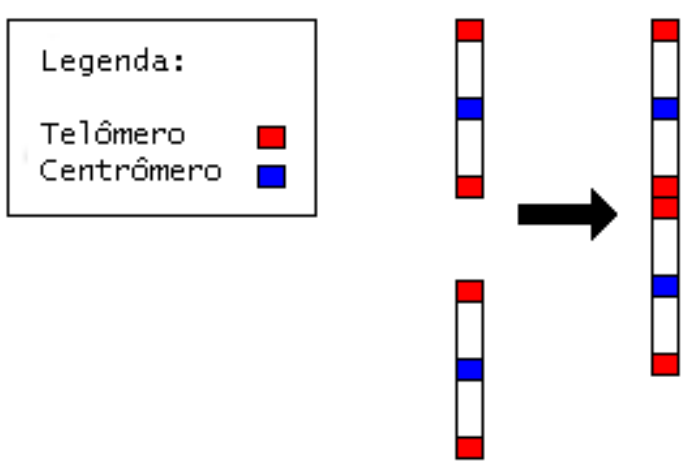

Figura 15 - llustração de processo de fusão

\subsubsection{OUTRAS ALTERAÇÕES CITOGENÉTICAS}

A maior parte do DNA das células está localizada nos cromossomos, mas uma pequena quantidade encontra-se em elementos extracromossômicos (EE), como o DNA mitocondrial e pequenas moléculas circulares covalentemente fechadas, de diferentes tipos, incluindo double minutes (dmin).

Double minutes (dmin) (Figura 16) e regiões homogeneamente coradas (HSRs) (Figura 17), que ocorrem em muitos tipos tumorais, são amplificações gênicas e correspondem a uma concentração imprópria de oncogenes. Double 


\section{Revisão de Literatura}

minutes são estruturas extracromossômicas de DNA circular (GAUBATZ, 1990), consistindo de 1 a 2 milhões de pares de bases que replicam de maneira autonoma, aproximadamente uma vez por ciclo celular, e segregam ao acaso para as células filhas, devido à ausência de centrômeros (CARROLL et al., 1987, 1993).

HSRs são estruturas amplificadas intracromossômicas que não estão necessariamente no locus nativo do gene. Ambos contêm genes que dão uma vantagem seletiva de proliferação às células tumorais onde eles ocorrem. Há uma hipótese de que regiões de DNA são excisadas do cromossomo como resultado de eventos de recombinação na forquilha de replicação (MITELMAN et al., 2007). Dependendo de seu tamanho, estas estruturas amplificadas podem conter alguns genes cromossômicos e resultariam numa deleção desses genes dos loci correspondentes. Este modelo ainda prediz que os epissomos multimerizam para formar estruturas circulares maiores, os dmin, que podem ser detectados citologicamente. Subsequentemente à sua formação, estes elementos de DNA extracromossômicos podem se integrar ao cromossomo, resultando em HSR.

Acredita-se que a seleção biológica para a geração e manutenção de sequências amplificadas de DNA em células tumorais seja dirigida pelo número de cópias aumentadas e expressão aumentada de genes alvo ou genes dentro de uma região maior de DNA amplificado. 


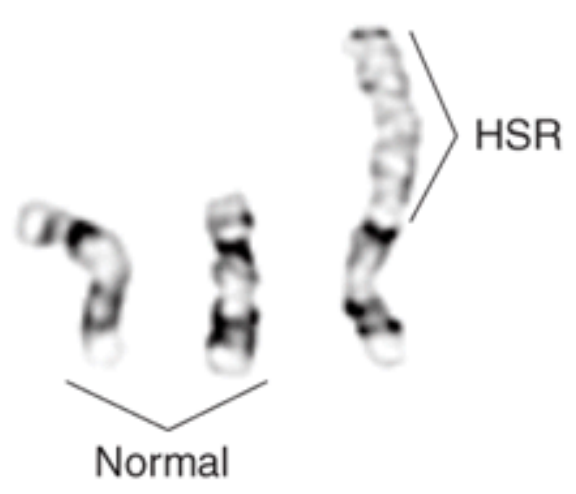

Figura 16 - Vizualização de HSR em cromossomo

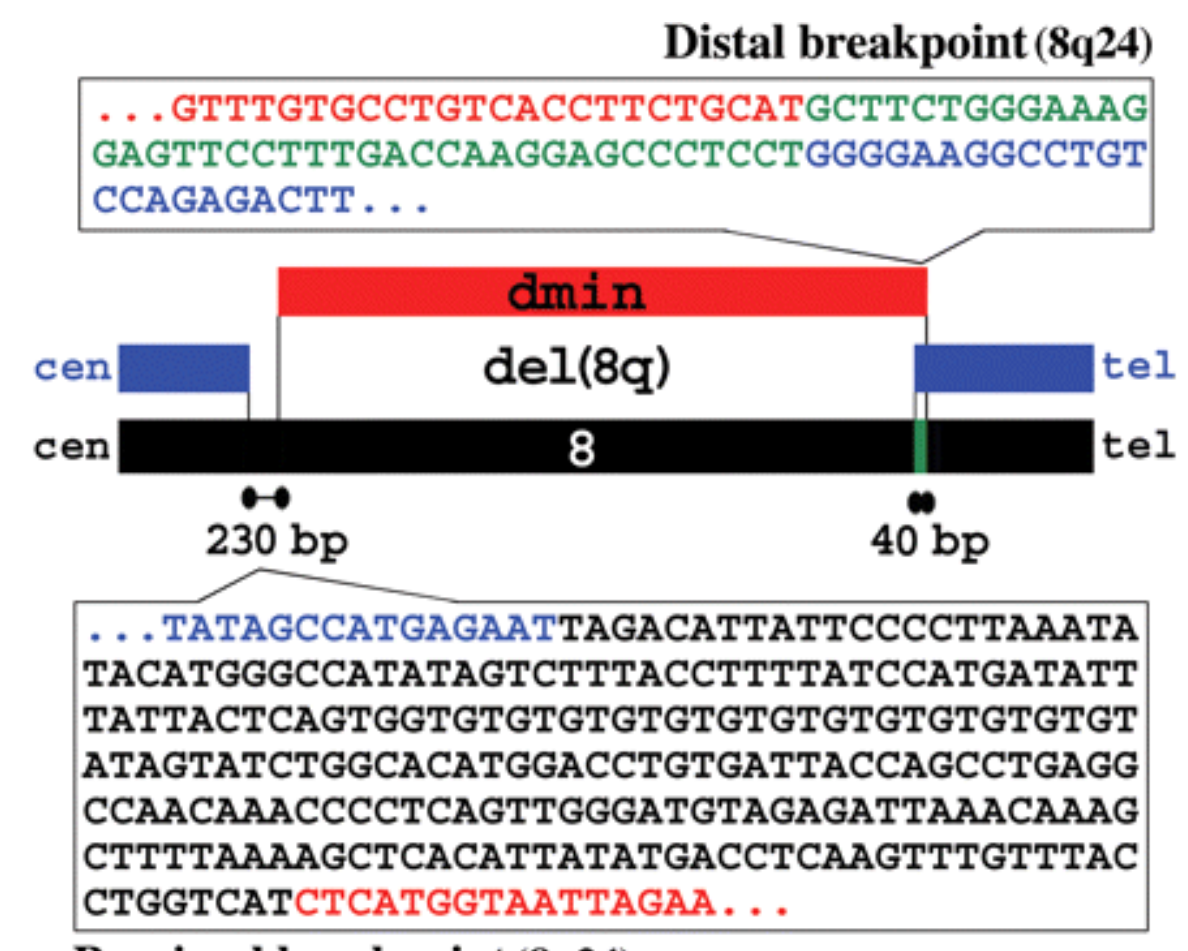

Proximal breakpoint (8q24)

Figura 17 - Representação esquemática de Double minutes 
2.4.7 CITOGENÉTICA CANINA

Durante os últimos 100 anos diversos relatos sobre a descrição do padrão cariotípico do cachorro foram publicados. Em muitos relatos, o número diplóide variou de 50 a 78 cromossomos (AHMED 1941; MINOUCHI 1927, PAINTER 1925; RATH 1894). Devido ao desenvolvimento de novas técnicas, como a hipotonização de células em cultura (HSU e POMERAT, 1953), o número diplóide de 78 cromossomos, sendo os 76 autossomos acrocêntricos, e os homólogos sexuais submetacêntricos, foi determinado para Canis familiaris (CHIARELLI 1966; GUSTAVSSON 1964; HARE et al. 1965). Esta morfologia aumenta a dificuldade com relação ao pareamento dos cromossomos. Assim, a maioria dos ideogramas foi inicialmente deduzida por mais de um cariótipo (SELDEN et al., 1975).

Com o desenvolvimento das técnicas de bandamento cromossômico foi possível chegar a uma descrição mais precisa do cariótipo canino. A primeira descrição de padrão de Banda $G$ foi publicada por SELDEN et al. (1975). Neste relato foi estabelecido um idiograma com 331 bandas por conjunto haplóide. Um ano depois, MANOLACHE et al. (1976) apresentou um esquema de representação com 230 bandas $G$ e um arranjo diferente dos cromossomos. Além disso, os autores descreveram os padrões das bandas $Q$ e $C$ do cariótipo canino.

$O$ próximo ideograma para banda $G$ de cromossomos caninos foi proposto por Fujinaga et al. (1989). Neste ideograma, o arranjo dos cromossomos seguiu os resultados apresentados por Manolache et al. (1976) e o número de bandas G por haplóide foi de 228. Este trabalho incluiu o padrão de banda $\mathrm{N}$ do cariótipo canino. Um outro ideograma foi produzido por Stone et al. (1991), usando a técnica de sincronização de células. Na representação esquemática obtiveram 327 bandas, e o arranjo dos cromossomos seguiu Selden et al. (1975). Graphodatsky et al. (1995) publicaram um ideograma canino com 460 bandas e suas características foram descritas. $O$ alinhamento dos cromossomos não seguiu nenhum dos trabalhos descritos anteriormente. 
Ainda, os ideogramas para banda $\mathrm{R}$ foram repetidamente descritos, cada qual com arranjos dos cromossomos e números de bandas diferentes (HOWARDPEEBLES e PRYOR 1980; POULSEN et al., 1990).

Durante o $11^{\text {th }}$ European Colloqium on Cytogenetics of Domestic Animals, de 1994, foi estabelecido o Comitê de Padronização do Cariótipo Canino, formado por 6 membros de diferentes laboratórios. A primeira medida deste grupo foi elucidar a questão de quantos pares de cromossomos poderiam ser reconhecidos inequivocadamente com $\mathrm{O}$ uso de técnicas de banda $\mathrm{G}$ em cromossomos em metáfase (REIMANN et al., 1999).

Os esforços resultaram na padronização de banda $G$ dos primeiros 21 autossomos e dos cromossomos sexuais (SWITONSKI et al. 1996). Baseado na resolução de bandas por esta técnica, bservou-se que para a identificação inequívoca dos 17 pares autossomos restantes seria necessária a integração de métodos da citogenética molecular. E somente em 1996, as colorações específicas para cromossomos caninos foram desenvolvidas por Langford et al., 1996.

Assim, a nomenclatura utilizada em estudos citogenéticos caninos segue padrões definidos pelo Comitê de padronização do cariótipo do cachorro (SELDEN et al., 1975; MAYR et al., 1983). No entanto, a nomenclatura para descrição de alterações cromossômicas de cariótipos caninos ainda não foi estabelecida. Nesses casos, recomenda-se a utilização da ISCN (1995) como referência (REIMANN et al., 1999).

Estudos citogenéticos envolvendo coloração convencional em células de carcinomas mamários revelaram casos de hipodiploidia, hiperdiploidia e tetraploidia cromossômicas (OWEN et al., 1977, 1981; ELSE et al., 1982; NORVALL et al. 1984; WOLFE et al., 1986).

Em 1990, um estudo realizado por Mayr e colaboradores caracterizou citogeneticamente, através da técnica de cariotipagem (HSU e MOORHEAD, 1956, modificado), um hemangiopericitoma canino, no qual foram analisadas células em metáfase. Todas as células tumorais apresentaram número reduzido de cromossomos $(2 n=74)$, além de serem observadas alterações estruturais como deleções e fusões cêntricas envolvendo os cromossomos 5/6, 5/14, 7/15 e 9/17, além de uma deleção no cromossomo 1. 
Estudos citogenéticos em dois casos de osteossarcoma canino revelaram alterações numéricas e estruturais como diversas fusões cêntricas identificadas nos cromossomos 1/3, 1/30 e 2/19 em um dos casos e 3/19, 12/18, 13/17 no outro animal (MAYR e ESCHBORN, 1991).

Avaliação citogenética de tumores mamários em dois cães domésticos (MAYR et al., 1991) constatou, em um dos animais, cariótipo normal em $20 \%$ das metáfases analisadas. No restante das células pôde-se detectar um marcador cromossômico, o qual é resultado de uma deleção terminal que afeta a metade distal do braço longo do cromossomo $\mathrm{X}$. O outro animal submetido à análise apresentou trissomia do cromossomo $1 \mathrm{em} 20 \%$ das metáfases estudadas e monossomia do $\mathrm{X}$ adicionalmente à trissomia do 1 em $30 \%$ das células em metáfase.

Em 1992, Mayr e Kramberger-Kaplan analisaram citogeneticamente sarcomas mamários caninos; em um dos casos verificaram que $60 \%$ das metáfases observadas apresentaram cariótipo normal, e no restante, alterações estruturais e numéricas.

Em 1994, Mayr analisou quatro tumores sólidos em cães e constatou alterações estruturais e numéricas na composição do cariótipo desses animais. Foram verificados cromossomos metacêntricos, fusões cêntricas e translocação.

As alterações cromossômicas estão associadas a fatores que controlam a replicação e o reparo do DNA, levando a predisposição ao câncer. Em muitos casos, a perda de função de genes supressores de tumor (como exemplo o p53) e ganho de função de oncogenes parece contribuir para o desenvolvimento de tumores (KRAEGEL, 1995, MAYR, 1999).

Através de análise citogenética em dois osteossarcomas caninos, foi possível detectar alterações numéricas e estruturais em todas as metáfases observadas. A metodologia seguiu protocolos de cultura das células tumorais de explantes primários e análise de metáfases coradas por Giemsa e por banda G (WANG E FEDOROFF, 1972). Em um dos cães, 25 células foram analisadas e todas as células apresentaram número de cromossomo hiperdiplóide, em torno de 85 a 99. Dentre as células investigadas, ocorreram fusões cêntricas $1 / 3,1 / 30,2 / 9$ e o cromossomo 5 estruturalmente alterado (der 5 ). No outro cão, foram analisadas 12 
células, dentre as quais houve contagem cromossômica de 65 a 67 . Todas as células apresentaram fusões cêntricas 3/19, 3/?, 12/18 e 13/17 (MAYR et al., 1991).

STONE et al. (1991) avaliaram citogeneticamente 4 mastocitomas caninos.

Os 4 tumores apresentaram células com hiperdiploidia e hipodiploidia, um aumento no número de cromossomos metacêntricos, mudanças de configuração, e células mostrando perda de um cromossomo X. Uma amostra de tumor apresentou 15\% das células avaliadas com um número cromossômico de 93.

A análise citogenética de melanoma maligno canino apresentou metade das metáfases analisadas com cariótipo canino normal $(2 n=78)$, sem detecção de alterações. Entretanto, as outras metáfases observadas apresentaram contagem de 79 a 81 cromossomos. Nessas células hiperdiplóides, foram observadas fusões cêntricas, parcialmente identificadas como 6/?, 10/? e 11/?. (MAYR et al., 1992)

Outro estudo analisou citogeneticamente sarcomas mamários em três cães, que apresentaram hiperdiploidia, fusões cêntricas e várias aberrações estruturais.

Em um dos cães, $60 \%$ das metáfases analisadas mostraram cariótipo canino normal $(2 n=78)$, sem nenhuma alteração detectada. Houve hiperdiploidia em $40 \%$ das células, com contagem cromossômica de 92 a 98 . No segundo cão, nenhuma das 15 metáfases analisadas apresentou cariótipo canino normal. Todas apresentaram 2n=76 e aberrações como um cromossomo 6 de braço duplo (6/?), um cromossomo 6 de braço único estruturalmente alterado (der 6).

No cão 3 , todas as 30 metáfases analisadas apresentaram alterações numéricas, sendo $70 \%$ hipodiplóides, com contagem de cromossomos de 60 a 66 . A identificação de bandas de fusões cêntricas foi incompleta devido ao tamanho muito pequeno dos braços de cromossomos participantes. Foram descritas uma quantidade de $30 \%$ das metáfases com hiperdiploidia, com contagem cromossômica de 115 a 128. Nestas células hiperdiplóides foram detectados entre 25 e 32 autossomos de braço duplo (MAYR et al., 1992).

Para que haja melhora na predição da evolução desta neoplasia há uma constante busca por indicadores de prognóstico, e a citogenética pode ser considerada uma ferramenta para diagnosticar e prever a evolução desta doença. 


\section{Pbjetivos}

\section{OBJETIVOS}

Com o objetivo particular de contribuir com a ciência e na elucidação de novas técnicas diagnósticas e terapêuticas veterinárias, este trabalho teve objetivos técnicos, que seguem descritos abaixo.

\subsection{OBJETIVOS GERAIS}

Este estudo tem como principal objetivo a comparação entre o cariótipo canino observado em linfócitos periféricos com cariótipo obtido a partir de células de massa tumoral de mastocitomas, buscando observar possíveis alterações nos cromossomos em cães da raça Boxer, portadores desta neoplasia.

\subsection{OBJETIVOS ESPECÍFICOS}

- Padronizar as técnicas de cariotipagem de células provenientes de mastocitomas caninos.

- Avaliar comparativamente o cariótipo de linfócitos periféricos e de células tumorais de cães da raça Boxer.

- Buscando detectar possíveis alterações cromossômicas numéricas e/ou estruturais nos cariótipos de tecidos tumorais. 
- Utilizar técnicas de Bandamento C e G para observar possíveis alterações cromossômicas.

- Identificar nos cromossomos caninos as Regiões Organizadoras de Nucléolos através da técnica de bandamento por nitrato de prata.

- Avaliar, se possível, a incidência de aberrações cromossômicas e associá-las ao grau de malignidade do tumor. 


\section{MATERIAL E MÉTODOS}

A seguir serão descritos, em etapas, os procedimentos realizados para a execução deste trabalho.

\subsection{MODELO EXPERIMENTAL}

Foi realizado um estudo retrospectivo para se estabelecer a prevalência da incidência de mastocitomas com relação às raças de cães. O levantamento pidemiológico foi realizado no Serviço de Patologia Animal do Hospital Veterinário da FMVZ - USP, e considerou os períodos entre Julho de 1999 e Julho de 2003 e de Agosto de 2004 até Abril de 2008, entre todos os casos de neoplasias caninas atendidos no setor. Dentre os casos de mastocitomas foram realizadas consultas aos prontuários dos animais. Todos os exames histopatológicas basearam-se na classificação de Patnaik (1984).

O levantamento epidemiológico acompanhou todos os animais que tiveram materiais coletados.

Para a execução deste experimento foram utilizados cerca de 30 cães de raças variadas acometidos de mastocitoma, sem idade prévia estabelecida e sem tratamento anterior, durante o período de padronização das técnicas, até que o resultado da cultura apresentasse número celular suficiente para viabilizar o protocolo de citogenética subsequente. Como critério de seleção, nenhum dos animais recebeu tratamento quimioterápico e/ou radioterápico prévio.

Dentre os animais da raça Boxer que tiveram os materiais coletados (sangue e tecido tumoral), 3 apresentaram bons resultados no protocolo de cultura e puderam ser analisados citogeneticamente: 
Número de identificação no experimento: $\mathbf{3 8}$

Data de coleta: 17/05/2007

Prontuário: 151626

Raça: Boxer

Nome: Chico

Sexo: Macho

Nascimento: 26/10/2000

Diagnóstico: Mastocitoma grau II

Número de identificação no experimento: $\mathbf{4 2}$

Data de coleta: 12/07/2007

Prontuário: 181648

Raça: Boxer

Nome: Naja

Sexo: Fêmea

Nascimento: 02/12/1997

Diagnóstico: Mastocitoma grau III

Número de identificação no experimento: 26

Data de coleta: 12/09/2007

Prontuário: 171469

Raça: Boxer

Nome: Mell

Sexo: Fêmea

Nascimento: 26/06/2000

Diagnóstico: Masocitoma grau II 
4.2 CLASSIFICAÇÃO DOS TUMORES

A citologia aspirativa por agulha fina foi realizada na consulta dos animais para estabelecer o diagnóstico inicial de mastocitoma e, após excisão cirúrgica, os tumores foram encaminhados ao Serviço de Patologia Animal do Hospital Veterinário (FMVZ-USP) e classificados de acordo com seu grau histológico e estadiamento, baseando na classificação de Patnaik (1984).

\subsection{COLETA DO SANGUE}

O sangue dos animais foi coletado com seringa estéril de $10 \mathrm{~mL}$, agulha de espessura 23 , com $700 \mu \mathrm{l}$ de heparina sódica utilizada como anticoagulante. $\mathrm{O}$ sangue colhido na seringa foi transferido para um tubo falcon estéril e centrifugado a 1800 rpm por 10 minutos a $37^{\circ} \mathrm{C}$ para sedimentação do material e formação do buffy coat com a separação das partes líquida e celular do sangue. Foram utilizados 500 $\mu l$ do anel leucocitário para realização da cultura celular.

\subsection{CULTURA CELULAR LEUCOCITÁRIA}

A cultura celular foi implantada a partir de $0,5 \mathrm{~mL}$ do anel leucocitário foi colocado em meio de cultura completo (RPMI 1640, L-glutamina 0,5\%, antibiótico penicilina estreptomicina $0,5 \%$, Soro fetal bovino $20 \%$ ) com $200 \mu \mathrm{l}$ de phitohemaglutinina-P durante 72 horas em estufa a $37^{\circ} \mathrm{C}, 5,0 \%$ de $\mathrm{CO}_{2}$. Todo o procedimento de preparo da cultura leucocitária foi realizado com condições de total assepsia em fluxo laminar Trox®. 
4.4.1 OBTENÇÃO DOS CROMOSSOMOS EM METÁFASE (HSU e MOORHEAD, 1956, modificado)

Decorridas 72 horas de incubação, foi efetuada a etapa de colchicinização. Para tanto, foram adicionados $100 \mu \mathrm{l}$ de colchicina [16 $\mu \mathrm{g} / \mathrm{mL}$ ] para cada $5 \mathrm{~mL}$ de volume final de cultura, e incubado em estufa a $37^{\circ} \mathrm{C}$ por 50 minutos.

Após a colchicinização foi realizada a etapa de hipotonização, onde o conteúdo da garrafa de cultura foi transferido para um tubo falcon e centrifugado a $1800 \mathrm{rpm}$ por 10 minutos a $37^{\circ} \mathrm{C}$. Cuidadosamente, o sobrenadante foi desprezado com auxílio de uma pipeta Pasteur e o pellet foi ressuspendido com o ajuste do volume do frasco para $7 \mathrm{~mL}$ com solução hipotônica ( $\mathrm{KCl} 0,075 \mathrm{M}$ ), adicionado cuidadosamente com o auxílio de uma pipeta Pasteur. O tubo foi incubado em banho-maria à $37^{\circ} \mathrm{C}$ durante 20 minutos. Após esse período, o tubo foi retirado do banho-maria, colocado em temperatura ambiente adicionadas 6 gotas de fixador gelado ( $75 \%$ de metanol e $25 \%$ de ácido acético) e homogeneizado, permanecendo assim por mais 10 minutos.

Decorrido o período de hipotonização, o material foi submetido à centrifugação de $1800 \mathrm{rpm}$ durante 10 minutos, para a fixação do material. O sobrenadante foi descartado e o volume do frasco foi ajustado para $7 \mathrm{~mL}$ com fixador gelado. O conteúdo foi homogeneizado e submetido novamente a centrifugação de $1800 \mathrm{rpm}$ durante 10 minutos. O sobrenadante foi desprezado com o auxílio da pipeta Pasteur e o pellet foi ressuspendido com o fixador gelado, ajustando o volume para $7 \mathrm{~mL}$. Esse procedimento foi realizado mais 2 vezes para retirar restos celulares da preparação. 


\subsubsection{PREPARO DAS LÂMINAS PARA COLORAÇÃO}

Depois de realizadas todas as etapas do processamento do material, resultando na obtenção de um pellet de preparação citogenética, a diluição do material foi ajustada com o fixador de forma que o material não ficasse saturado. A lâmina utilizada foi limpa com álcool $70 \%$ e fralda macia. A lâmina limpa foi colocada sobre um suporte dentro do banho-maria a $60^{\circ} \mathrm{C}$ para que ficasse aquecida. Desta forma o material da preparação citogenética foi pingado na lâmina com a pipeta Pasteur, a uma altura média de $30 \mathrm{~cm}$ de altura. Após a secagem do material (24 horas em temperatura ambiente), as lâminas ficaram prontas para serem submetidas às técnicas de coloração.

\subsection{CULTURA PRIMÁRIA DE MASTOCITOMAS (DEVINNEY e GOLD, 1990)}

Foram utilizados fragmentos de tumores que receberam diagnóstico de mastocitoma do Serviço de Patologia Animal do Departamento de Patologia (FMVZUSP) através de citologia aspirativa provenientes de cães. Esses materiais foram obtidos no Serviço de Cirurgia do Hospital Veterinário (FMVZ-USP). Os fragmentos foram mantidos em meio de cultura RPMI em temperatura ambiente até no máximo 1 hora antes do início da preparação dos cultivos. No laboratório, em condições assépticas, os fragmentos de mastocitomas caninos foram mecanicamente fragmentados em pedaços de aproximadamente $1 \mathrm{~mm}$ e incubados em solução de colagenase tipo IA de Clostridium histolyticum (100U/ml) em RPMI e antibióticos por cerca de 2 horas, a $37^{\circ} \mathrm{C}$ e em banho-maria com agitação.

A suspensão celular resultante foi filtrada em gaze e posteriormente em filtro de $70 \mu \mathrm{m}$. Todo o conteúdo foi centrifugado a $1200 \mathrm{rpm}$ por 10 minutos e o sobrenadante foi descartado. As células sedimentadas foram ressuspendidas em 10 $\mathrm{ml}$ de RPMI suplementado com $10 \%$ de Soro Fetal Bovino, antibióticos e colocadas 
em cultura em estufa a $37^{\circ} \mathrm{C}, 5,0 \%$ de $\mathrm{CO}_{2}$. A garrafa de cultura foi observada diariamente até que as células apresentassem um alto índice de divisão, o que ocorreu com 96 horas de incubação (Figura 18).

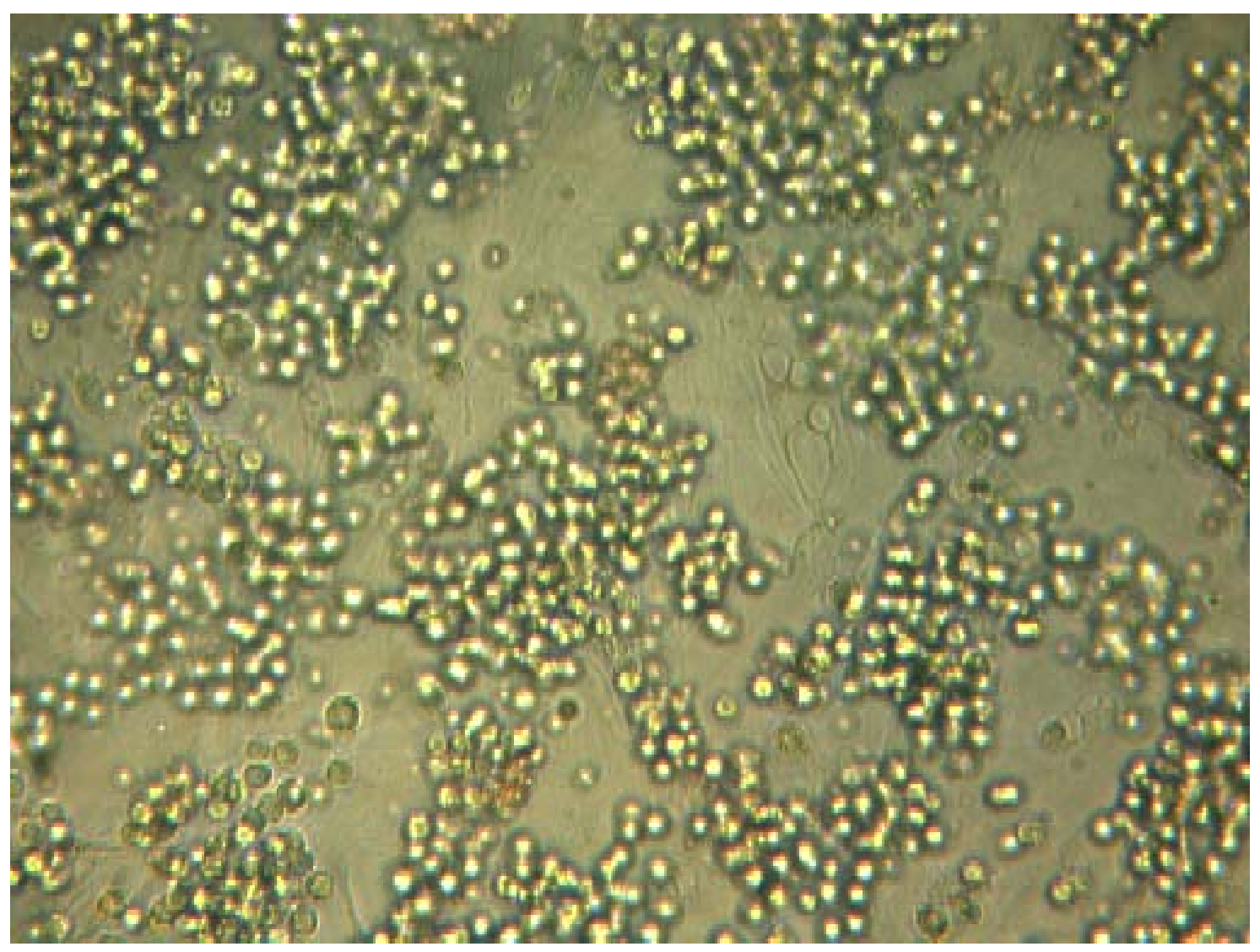

Figura 18 - Tecido tumoral de mastocitoma em cultura. Presença de mastócitos e fibroblastos. Visualização em microscópio invertido Motic (200x). 


\subsubsection{PROCESSAMENTO PARA AQUISIÇÃO DOS CROMOSSOMOS EM METÁFASE (HSU e MOORHEAD, 1956, modificado)}

Decorrido o período de incubação da cultura celular, foi efetuada a etapa de colchicinização. Para tanto, foram adicionados $100 \mu \mathrm{l}$ de colchicina [16 $\mu \mathrm{g} / \mathrm{mL}$ ] para cada $5 \mathrm{~mL}$ de volume final de cultura, e incubado na estufa a $37^{\circ} \mathrm{C}$ por 50 minutos.

Após a etapa de colchicinização, foi realizada a tripsinização das células cultivadas. Nesta etapa a suspensão da garrafa de cultura foi retirada e armazenada em tubo falcon. Foram adicionados na garrafa $3 \mathrm{~mL}$ de solução Hank's (sem cálcio e sem magnésio) e incubado na estufa por 20 minutos. Posteriormente, a solução Hank's foi retirada da garrafa de cultura e armazenada juntamente com o meio de cultura retirado na etapa anterior. Foi adicionada uma quantidade de $2 \mathrm{~mL}$ de tripsina EDTA na garrafa de cultura, que foi submetida a pequena agitação para que as células aderidas se desprendessem da parede da garrafa de cultura. Esse procedimento não ultrapassa 1 minuto. A solução com tripsina e as células desprendidas foi adicionada ao conteúdo retirado anteriormente e tudo foi centrifugado a $1800 \mathrm{rpm}$ durante 10 minutos. O sobrenadante foi desprezado com auxílio da pipeta Pasteur.

Após a tripsinização foi realizada a etapa de hipotonização. Todo o conteúdo do tubo foi transferido para um tubo falcon e centrifugado a $1800 \mathrm{rpm}$ por 10 minutos à $37^{\circ} \mathrm{C}$. Cuidadosamente, o sobrenadante foi desprezado com auxílio de uma pipeta Pasteur e o pellet foi ressuspendido com o ajuste do volume do frasco para $7 \mathrm{~mL}$ com solução hipotônica $(\mathrm{KCl} 0,075 \mathrm{M})$, adicionado cuidadosamente com o auxílio de uma pipeta Pasteur. $\mathrm{O}$ conteúdo do tubo foi incubado em banho-maria à $37^{\circ} \mathrm{C}$ durante 20 minutos. Após esse período, o tubo foi retirado do banho-maria e colocado em temperatura ambiente, sendo adicionadas 6 gotas de fixador gelado( $75 \%$ de metanol e $25 \%$ de ácido acético) ao conteúdo e homogeneizado, permanecendo assim por mais 10 minutos.

Decorrido o período de hipotonização, o material foi submetido à centrifugação de $1800 \mathrm{rpm}$ durante 10 minutos, para a fixação do material. O sobrenadante foi descartado e o volume do frasco foi ajustado para $7 \mathrm{~mL}$ com fixador gelado. O conteúdo foi homogeneizado e submetido novamente a 
centrifugação de $1800 \mathrm{rpm}$ durante 10 minutos. O sobrenadante foi desprezado com o auxílio da pipeta Pasteur e o pellet foi ressuspendido com o ajuste do volume para $7 \mathrm{~mL}$ com o fixador gelado, adicionado cuidadosamente. Esse procedimento foi realizado mais 2 vezes para retirar restos celulares da preparação.

\subsubsection{PREPARO DAS LÂMINAS PARA COLORAÇÃO}

Após a obtenção de um pellet de preparação citogenética, a diluição do material foi ajustada com o fixador de forma que o material não ficasse saturado. $\mathrm{A}$ lâmina utilizada foi limpa com álcool $70 \%$ e fralda macia. A lâmina limpa foi colocada sobre um suporte dentro do banho-maria a $60^{\circ} \mathrm{C}$ para que ficasse aquecida. Desta forma o material da preparação citogenética foi pingado na lâmina com a pipeta Pasteur, a uma altura média de $30 \mathrm{~cm}$ de altura. Após a secagem do material (24 horas em temperatura ambiente), as lâminas ficaram prontas para serem submetidas às técnicas de coloração.

\subsection{TÉCNICAS DE COLORAÇÃO}

\subsubsection{COLORAÇÃO CONVENCIONAL}

As lâminas foram hidrolisadas em solução $\mathrm{HCl} 1 \mathrm{~N}$, com banho de 7 minutos a $60^{\circ} \mathrm{C}$ e lavadas com água destilada. Após alguns minutos de secagem, as lâminas foram coradas com Giemsa (1:30) em tampão fosfato por 7 minutos e lavadas com água destilada. Após secagem, as lâminas foram submetidas à análise. 
4.6.2 BANDA C (CBG), segundo Sumner (1972), com modificações

As lâminas foram hidrolisadas em $\mathrm{HCl} 0,2 \mathrm{~N}$ durante 30 minutos à temperatura ambiente e lavadas com água destilada. Após alguns minutos de secagem, as lâminas foram mergulhadas em hidróxido de bário octahidratado $5 \%$ a $60^{\circ} \mathrm{C}$, durante 10 segundos, aproximadamente. Imediatamente em seguida, as lâminas foram lavadas com água destilada e passadas rapidamente em $\mathrm{HCl} 1 \mathrm{~N} \mathrm{a} 60^{\circ} \mathrm{C}$. Após este procedimento, estas foram lavadas em água destilada e secas. Posteriormente, as lâminas foram incubadas em solução de $2 x S S C(p H 7,0)$ a $60^{\circ} \mathrm{C}$ durante 15 minutos, lavadas em água destilada e secas. As lâminas foram coradas com Giemsa (1:20) em tampão fosfato por 30 minutos e lavadas com água destilada. Após secagem, as lâminas foram submetidas à análise.

4.6.3 BANDA G (GTG), segundo Seabright (1971), com modificações

As lâminas foram hidrolisadas por 15 minutos em $2 \times S S C$ a $60^{\circ} \mathrm{C}$ e lavadas com água destilada. Após alguns minutos de secagem, as lâminas foram mergulhadas em uma solução de tripsina $(0,02 \mathrm{~g} \mathrm{em} 75 \mathrm{ml}$ tampão fosfato $\mathrm{pH} 6,8)$ a $37^{\circ} \mathrm{C}$, com movimentos para frente e para trás, durante 8 segundos, aproximadamente. Após este procedimento, estas foram lavadas em água destilada, secas e coradas com Giemsa (1:30) em tampão fosfato por 7 minutos e lavadas com água destilada. Após secagem, as lâminas foram submetidas à análise.

4.6.4 BANDA RON (REGIÕES ORGANIZADORAS DE NUCLÉOLOS), segundo Howell e Black (1980), com modificações

As lâminas foram hidrolisadas em $\mathrm{HCl} 1 \mathrm{~N} \mathrm{a} 60^{\circ} \mathrm{C}$ por 7 minutos à temperatura ambiente e lavadas com água destilada. Após alguns minutos de secagem, foi pingada sobre o material da lâmina 1 gota de solução coloidal reveladora (1g de 
elatina para microbiologia da Merck® em $50 \mathrm{ml}$ de água destilada com $0,5 \mathrm{ml}$ de ácido fórmico) e duas gotas de solução de nitrato de prata $\left(\mathrm{AgNO}_{3}\right) 50 \%$. Estas foram cobertas com lamínulas e incubadas em câmara úmida a 60 por cerca de 3 a 4 minutos. Após este período, as lamínulas foram retiradas, as lâminas foram lavadas com água destilada e coradas com solução de Giemsa (Merck®) 1:50 durante 30 segundos.

\subsection{ANÁLISE DAS METÁFASES}

Após a secagem completa das lâminas, o material foi analisado e fotografado em microscópio de imersão da marca Zeiss $\AA$, em objetiva de 100x, com filtro verde, equipado com software de análise citogenética Ikaros $₫$. Foram consideradas alterações numéricas e estruturais.

Foram consideradas metáfases completas para análise aquelas que se apresentavam com material bem espalhado sobre a lâmina e com boa visualização, o que implica na condensação do material genético e poderão ser observadas posteriormente, no capítulo de resultados.

Todas as metáfases fotografadas foram identificadas conforme a localização na lâmina (coordenada do microscópio), número da lâmina e número da metáfase, para controle, rastreabilidade e fidedignidade dos dados.

Os cromossomos foram computados com auxílio de ferramenta específica do sistema de análise citogenética na investigação de alterações numéricas, assim como foram também observados com a intenção de buscar alterações estruturais.

As metáfases de linfócitos periféricos e de células de tecido tumoral foram analisadas em coloração convencional (Giemsa), bandas G, bandas C e bandas Rons. 


\section{RESULTADOS}

Nesta etapa estarão descritos e justificados os resultados de todos os procedimentos realizados neste trabalho.

\subsection{ESTUDOS RETROSPECTIVOS}

O estudo retrospectivo realizado sobre a incidência de mastocitomas em cães no período entre julho de 1999 e julho de 2003, analisou os laudos histopatológicos, obtidos no Setor de Anatomia Patológica, FMVZ-USP, que foram avaliados. Do total de 4090 exames histopatológicos realizados no período, 2,3\% dos laudos (94) eram relacionados aos casos de mastocitomas em cães, dos quais 53 animais $(56,4 \%)$ eram machos. A idade variou entre um e 15 anos, com média de 8,13 $\pm 3,02 ; 58,6 \%$ dos cães apresentaram-se na faixa etária entre sete e dez anos.

Houve maior prevalência de mastocitomas em animais sem raça definida $(37,2 \%)$, Boxer $(27,7 \%)$ e Poodle $(7,4 \%)$. Relacionado à distribuição dos tumores, as regiões cutâneas mais acometidas foram escroto $(25,5 \%)$ e mama $(7,4 \%)$. Dentre os tumores analisados, $14 \%$ apresentaram comprometimento das margens cirúrgicas, 6,4\% ocorreram juntamente com seminoma, 5,3\% com Leydigoma e 3,2\% com hemangioma.

De acordo com a classificação de Patnaik (1984), 16\% dos tumores apresentaram grau I, 26,6\% grau II, 16\% grau III e 4,3\% apresentaram graus II e III no mesmo animal. Um total de $37,2 \%$ dos mastocitomas não apresentou a classificação conforme o grau descritas no prontuário.

Através do levantamento de dados de exames histopatológicos realizados pelo Serviço de Patologia Animal do HOVET - FMVZ - USP, no período 
compreendido entre agosto de 2004 e abril de 2008, foram registrados 206 casos de mastocitomas em cães.

No que se refere à raça, $31 \%$ dos casos ocorreram em animais da raça Boxer, seguidos de $24 \%$ de animais sem raça definida, $8 \%$ de Labradores e o restante $(37 \%)$ correspondente ao total das outras raças, o que não corresponde a uma raça pura.

A idade dos cães variou entre três e 15 anos, com prevalência de $42 \%$ dos animais com faixa etária entre sete e dez anos. Os animais do sexo feminino representaram um percentual de $53 \%$ das ocorrências. De acordo com a graduação histopatológica baseada em Patnaik (1984), a maioria dos casos, representada com um total de $56 \%$, obteve diagnóstico de mastocitoma grau II, seguido de $23 \%$ de animais com mastocitoma grau I e $12 \%$ com diagnóstico de mastocitoma grau III. Houve um pequeno percentual de animais acometidos de mais de um tipo de graduação histopatológica do mastocitoma.

\subsection{PADRONIZAÇÃO DAS TÉCNICAS}

Foram incluídos no experimento os materiais de cães de diferentes raças até que as técnicas fossem padronizadas. Após a padronização das técnicas de cultura e protocolo de citogenética, foram coletados somente os materiais provenientes dos cães da raça Boxer.

Para a padronização da técnica de cultura de células para utilização em protocolo de citogenética, foram realizados testes. Foram avaliados três períodos de tempo $(48,72$ e 96 horas) para a incubação em estufa a $37^{\circ} \mathrm{C}, 5,0 \%$ de $\mathrm{CO}_{2}$. O período que apresentou melhores resultados na divisão das células foi de 72 horas para cultura de linfócitos periféricos e 96 horas para cultura primária do tecido tumoral.

Depois de padronizado o período de incubação, foram analisadas etapas do protocolo de cariotipagem das células resultantes da cultura. Para estabelecer a 
concentração do $\mathrm{KCl}$ para lise das células, foram comparados métodos de outros trabalhos publicados. Foram testadas duas concentrações do reagente: $0,075 \mathrm{M}$ e $0,04 \mathrm{M}$, e a primeira proporcionou a permeabilidade das células sem que essas perdessem o seu conteúdo cromossômico (Figura 19).

O período de incubação do material de cultura com a colchicina também foi bem definido, já que os cromossomos se apresentavam com as cromátides separadas caso o tempo fosse prorrogado (Figura 20), mesmo que por poucos minutos. Esse tempo então foi padronizado em 50 minutos para as culturas de células tumorais e de 60 minutos para as culturas de linfócitos periféricos.

Foi necessário estabelecer uma altura para pingar o material sobre a lâmina para que este pudesse se espalhar sobre a superfície. Para esse procedimento, as lâminas ficaram sobre uma estante localizada dentro do banho-maria e o material era pingado com a utilização da pipeta Pasteur. Nos primeiros experimentos, o material foi pingada a uma altura média de $20 \mathrm{~cm}$, o que fazia com que as metáfases fossem observadas muito próximas umas das outras, não permitindo uma análise fidedigna. Após alguns testes, observou-se que a melhor altura para depositar o material sobre a lâmina encontra-se entre 35 e $40 \mathrm{~cm}$.

Os testes referentes às colorações foram estabelecidos com relação aos tempos de reação com as soluções. Por exemplo o período padronizado para banho em tripsina, para coloração de bandamento $\mathrm{G}$, foi de nove segundos em movimento, a $60^{\circ} \mathrm{C}$. Para banho em bário $5 \%$ para bandamento $C$, foi estabelecido o período de 25 segundos em movimento, a $60^{\circ} \mathrm{C}$. O período de contato das lâminas com a solução de nitrato de prata foi padronizado em três minutos e 15 segundos.

Enquanto eram padronizados os tempos de reação com as soluções, foram observados diferentes resultados, como a corrosão excessiva do material cromossômico quando o tempo em contato com a substância era excedente. 


\subsection{OS ANIMAIS}

Dentre os animais da raça Boxer previamente selecionados, obtivemos uma boa qualidade do material tumoral e divisão celular de três animais, os quais foram submetidos ao protocolo de cultura de células e citogenética.

Depois do procedimento cirúrgico, os animais analisados tiveram acompanhamento quanto à realização de tratamentos e tempo de sobrevida.

O cão Chico apresentou um mastocitoma em membro posterior, com formação tumoral em tecido subcutâneo, evolução de 30 meses e intervalo de 12 meses para recidiva. O animal não apresentou comprometimento das margens cirúrgicas nem metástase, e apresentou grau II segundo a classificação de Patnaik (1984). O animal ainda está vivo.

A cadela Naja apresentou o mastocitoma em membro posterior e cabeça, com nove formações tumorais, evolução de 24 meses e abrangência dérmica. $O$ animal não apresentou comprometimento das margens cirúrgicas nem metástase, e apresentou graduação tumoral III segundo a classificação de Patnaik (1984). A cadela teve sobrevida de 12 meses após a intervenção cirúrgica e evoluiu ao óbito.

A cadela Mell apresentou o mastocitoma em membro posterior e dorso, com duas formações tumorais, evolução de dois meses e abrangência dérmica. $O$ animal não apresentou comprometimento das margens cirúrgicas nem metástase, apresentou grau II segundo a classificação de Patnaik (1984). Houve um período de cinco meses para recidiva do tumor, que estava sendo controlado até que o animal contraiu leptospirose, o que piorou seu estado clínico devido à debilidade, evoluindo ao óbito. 


\subsection{ALTERAÇOES GENÉTICAS}

Foi realizado um estudo comparativo para avaliação numérica de cromossomos, onde foram analisadas metáfases de linfócitos periféricos e metáfases de células de tecido tumoral em cinco cães, dentre as raças Boxer, Pug, Labrador um animal sem raça definida. A idade dos cães variou entre sete e 12 anos e todos os tumores foram classificados como mastocitoma grau II.

Após as preparações citogenéticas, foram analisadas 20 células de cada tipo de material de cada animal. $\mathrm{Na}$ análise realizada, a contagem cromossômica nas metáfases de linfócitos periféricos não apresentou alterações, mantendo o número diplóide de $2 n=78$; no entanto, houve variação entre 74 e 79 cromossomos observados no material proveniente de células dos tumores dos animais.

\subsection{A RAÇA BOXER E AS ALTERAÇÕES CITOGENÉTICAS}

Os resultados das análises citogenéticas aqui descritos são referentes à análise específica dos materiais provenientes dos três cães da raça Boxer supracitados. De todo material coletado dos cães, foi possível confeccionar lâminas com material citogenético de linfócitos periféricos e de células tumorais.

Foram analisadas um total de 828 metáfases, parcialmente divididas para análises em colorações convencional, bandas $\mathrm{G}$, bandas $\mathrm{C}$ e bandas Rons (Tabelas 1, 2, 3 e 4).. Provenientes de linfócitos periféricos foram fotografadas e analisadas 476 metáfases. Um total de 352 metáfases foi analisado do material tumoral dos animais. 


\begin{tabular}{|c|c|c|c|c|c|c|}
\hline \multicolumn{7}{|c|}{ Análise em coloração convencional } \\
\hline Animal & Met. & $2 n=78$ & $2 n=77$ & $2 n=79$ & $2 n=76$ & $2 n=75$ \\
\hline $26 S$ & 74 & 74 & 0 & 0 & 0 & 0 \\
\hline $26 \mathrm{~T}$ & 79 & 58 & 14 & 1 & 6 & 2 \\
\hline $38 \mathrm{~S}$ & 67 & 67 & 0 & 0 & 0 & 0 \\
\hline $38 \mathrm{~T}$ & 102 & 64 & 22 & 1 & 15 & 0 \\
\hline $42 S$ & 94 & 93 & 1 & 0 & 0 & 0 \\
\hline $42 \mathrm{~T}$ & 52 & 37 & 9 & 0 & 6 & 0 \\
\hline
\end{tabular}

Tabela 1 - Met: número de metáfases analisadas; 26S: animal 26, linfócitos periféricos; 26T: animal 26, células tumorais; 38S: animal 38, linfócitos periféricos; 38T: animal 38, células tumorais; 42S: animal 42, linfócitos periféricos; 42T: animal 42 , células tumorais

\begin{tabular}{|c|c|c|c|c|c|}
\hline \multicolumn{6}{|c|}{ Análise com Bandamento $\mathrm{C}$} \\
\hline Animal & Met. & $2 n=78$ & $2 n=77$ & $2 n=79$ & $2 n=76$ \\
\hline $26 S$ & 25 & 25 & 0 & 0 & 0 \\
\hline $26 \mathrm{~T}$ & 10 & 9 & 0 & 0 & 1 \\
\hline $38 \mathrm{~S}$ & 16 & 16 & 0 & 0 & 0 \\
\hline $38 \mathrm{~T}$ & 10 & 9 & 1 & 0 & 0 \\
\hline $42 S$ & 22 & 22 & 0 & 0 & 0 \\
\hline $42 \mathrm{~T}$ & 0 & 0 & 0 & 0 & 0 \\
\hline
\end{tabular}

Tabela 2 - Met: número de metáfases analisadas; 26S: animal 26, linfócitos periféricos; 26T: animal 26, células tumorais; 38S: animal 38, linfócitos periféricos; 38T: animal 38, células tumorais; 42S: animal 42, linfócitos periféricos; 42T: animal 42, células tumorais 
Material e Métodos

\begin{tabular}{|c|c|c|c|c|c|}
\hline \multicolumn{6}{|c|}{ Análise com Bandamento Ron } \\
\hline Animal & Met. & $2 n=78$ & $2 n=77$ & $2 n=79$ & $2 n=76$ \\
\hline $26 S$ & 30 & 30 & 0 & 0 & 0 \\
\hline $26 \mathrm{~T}$ & 30 & 21 & 7 & 1 & 1 \\
\hline $38 S$ & 20 & 20 & 0 & 0 & 0 \\
\hline $38 \mathrm{~T}$ & 20 & 13 & 5 & 0 & 2 \\
\hline $42 S$ & 20 & 20 & 0 & 0 & 0 \\
\hline $42 \mathrm{~T}$ & 9 & 6 & 1 & 0 & 2 \\
\hline
\end{tabular}

Tabela 3 - Met: número de metáfases analisadas; 26S: animal 26, linfócitos periféricos; 26T: animal 26, células tumorais; 38S: animal 38, linfócitos periféricos; 38T: animal 38, células tumorais; 42S: animal 42, linfócitos periféricos; 42T: animal 42, células tumorais

\begin{tabular}{|c|c|c|c|c|c|}
\hline \multicolumn{6}{|c|}{ Análise com Bandamento G } \\
\hline Animal & Met. & $2 n=78$ & $2 n=77$ & $2 n=79$ & $2 n=76$ \\
\hline $26 S$ & 68 & 68 & 0 & 0 & 0 \\
\hline $26 \mathrm{~T}$ & 20 & 17 & 1 & 1 & 1 \\
\hline $38 \mathrm{~S}$ & 20 & 20 & 0 & 0 & 0 \\
\hline $38 \mathrm{~T}$ & 20 & 16 & 2 & 1 & 1 \\
\hline $42 S$ & 20 & 19 & 1 & 0 & 0 \\
\hline $42 \mathrm{~T}$ & 0 & 0 & 0 & 0 & 0 \\
\hline
\end{tabular}

Tabela 4 - Met: número de metáfases analisadas; 26S: animal 26, linfócitos periféricos; 26T: animal 26, células tumorais; 38S: animal 38, linfócitos periféricos; 38T: animal 38, células tumorais; 42S: animal 42, linfócitos periféricos; 42T: animal 42, células tumorais 
A análise das metáfases provenientes de cultura de células dos linfócitos periféricos não apresentou alterações estruturais. A análise numérica mostrou uma metáfase com $2 n=77$, e todas as outras mostraram número diplóide habitual canino.

$\mathrm{Na}$ análise das metáfases de células tumorais, entre todas as colorações, foram observadas as primeiras alterações. Dentre as 352 metáfases analisadas, $70,9 \%$ apresentou número diplóide normal, $2 n=78$. Outros $17,4 \%$ das metáfases mostraram $2 n=77 ; 9,8 \%$ tinham $2 n=76$. Cinco metáfases $(1,3 \%)$ apresentaram $2 n=79$ e duas células apresentaram $2 n=75$. Alguns resultados de análises estão incluído nas tabelas 5 e 6 .

\begin{tabular}{|l||c||c||r||}
\hline Tipo color. & LP & T & Total \\
\hline \hline Convencional & 235 & 233 & 468 \\
\hline \hline Banda G & 108 & 40 & 148 \\
\hline \hline Banda C & 63 & 20 & 83 \\
\hline Banda Ron & 70 & 59 & 129 \\
\hline \hline Total & 476 & 352 & 828 \\
\hline \hline
\end{tabular}

Tabela 5 - Número de metáfases analisadas por tipo de coloração. LP: metáfases de linfócitos periféricos; $T$ : metáfases de células tumorais

\begin{tabular}{|c||c||c|}
\hline $\mathbf{2 n}$ & $\mathbf{T}$ & \% \\
\hline \hline $\mathbf{7 8}$ & 250 & 70,9 \\
\hline \hline $\mathbf{7 7}$ & 62 & 17,4 \\
\hline \hline $\mathbf{7 6}$ & 35 & 9,8 \\
\hline $\mathbf{7 9}$ & 5 & 1,3 \\
\hline $\mathbf{7 5}$ & 2 & 0,6 \\
\hline \hline Total & 352 & 100 \\
\hline
\end{tabular}

Tabela 6 - Incidência de metáfases por número diplóide 
Foram também encontradas alterações estruturais nas análises realizadas nos cromossomos em metáfase de cultura de células tumorais dos três animais.

Houve ocorrência de cromossomos metacêntricos e submetacêntricos além dos cromossomos sexuais, presença de regiões mais coradas em determinadas partes dos cromossomos.

Com relação à incidência de aberrações cromossômicas associadas ao grau de malignidade dos tumores, não houve diferença significativa na análise das metáfases. Os três animais apresentaram alterações numéricas e estruturais semelhantes em número e estrutura.

A coloração por nitrato de prata marcou a extremidade dos cromossomos na região centromérica, permitindo a visualização das regiões organizadoras de nucléolos.

As próximas páginas seguem com figuras descritas com algumas das alterações encontradas. 


\section{Material e Métodos}

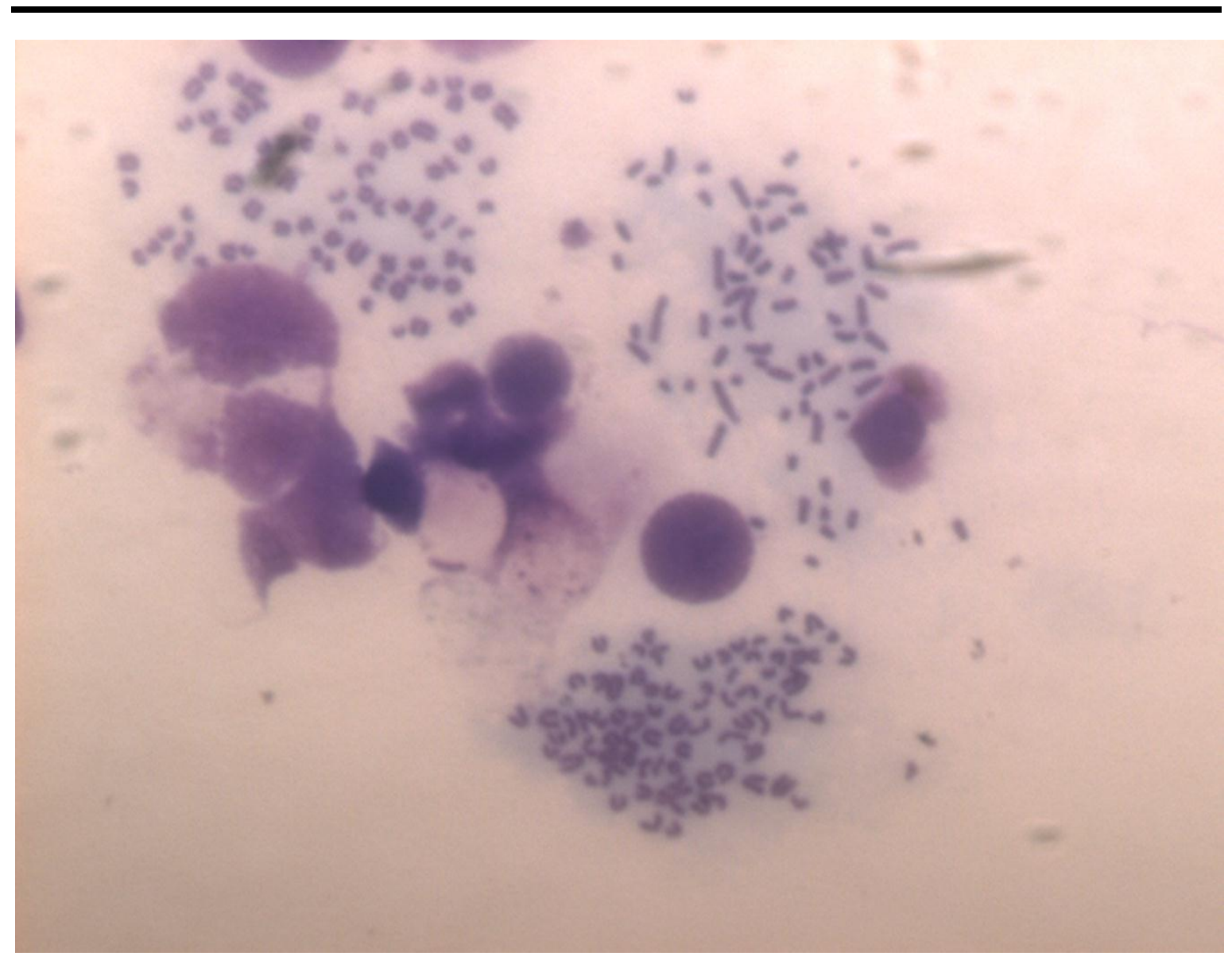

Figura 19 - Metáfase de tecido tumoral. Cão SRD Fêmea. Observação de 3 células com cromossomos em metáfases muito próximas, o que não permite análise pela possibilidade de confusão entre os cromossomos 
Figura 20: Metáfase de tecido tumoral. Cão Boxer macho. Os braços dos cromossomos separados (seta), resultantes da ação demasiada da colchicina. Visualização em microscópio Zeiss (1000x) e filtro verde. Após alguns testes foi padronizado o tempo de ação da colchicina de 50 minutos em estufa $37^{\circ} \mathrm{C}$ e $5 \%$ de $\mathrm{CO}_{2}$, para que os cromossomos permanecessem íntegros 


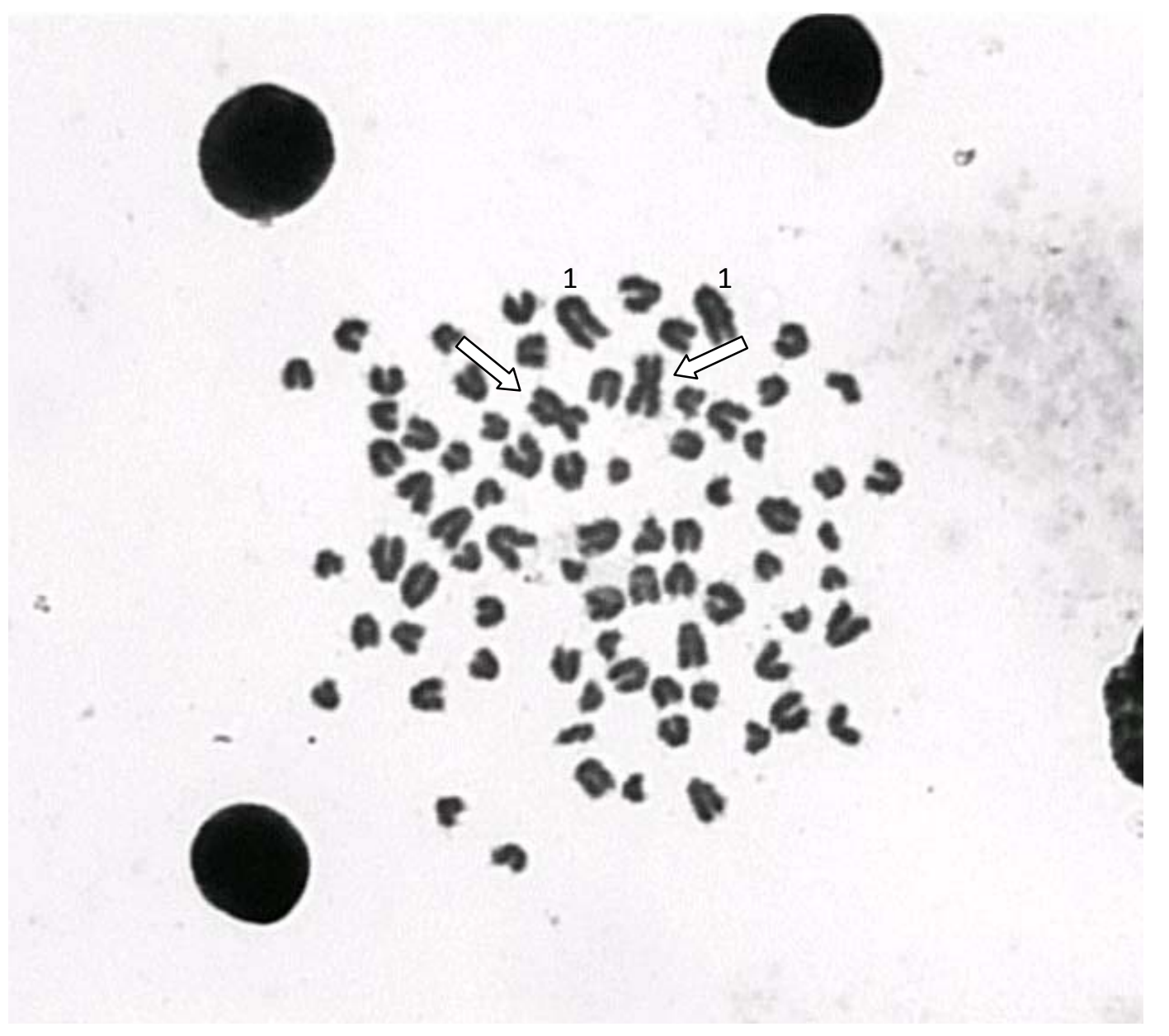

Figura 21 - Metáfase mitótica canina obtida a partir de cultura de linfócitos periféricos. Cão Boxer fêmea $(2 n=78)$. As setas largas brancas indicam o par de cromossomos sexuais $X X$ e o primeiro par está indicado com o número 1. Coloração convencional. Visualização em microscópio Zeiss (1000x) e filtro verde 


\section{Material e Métodos}

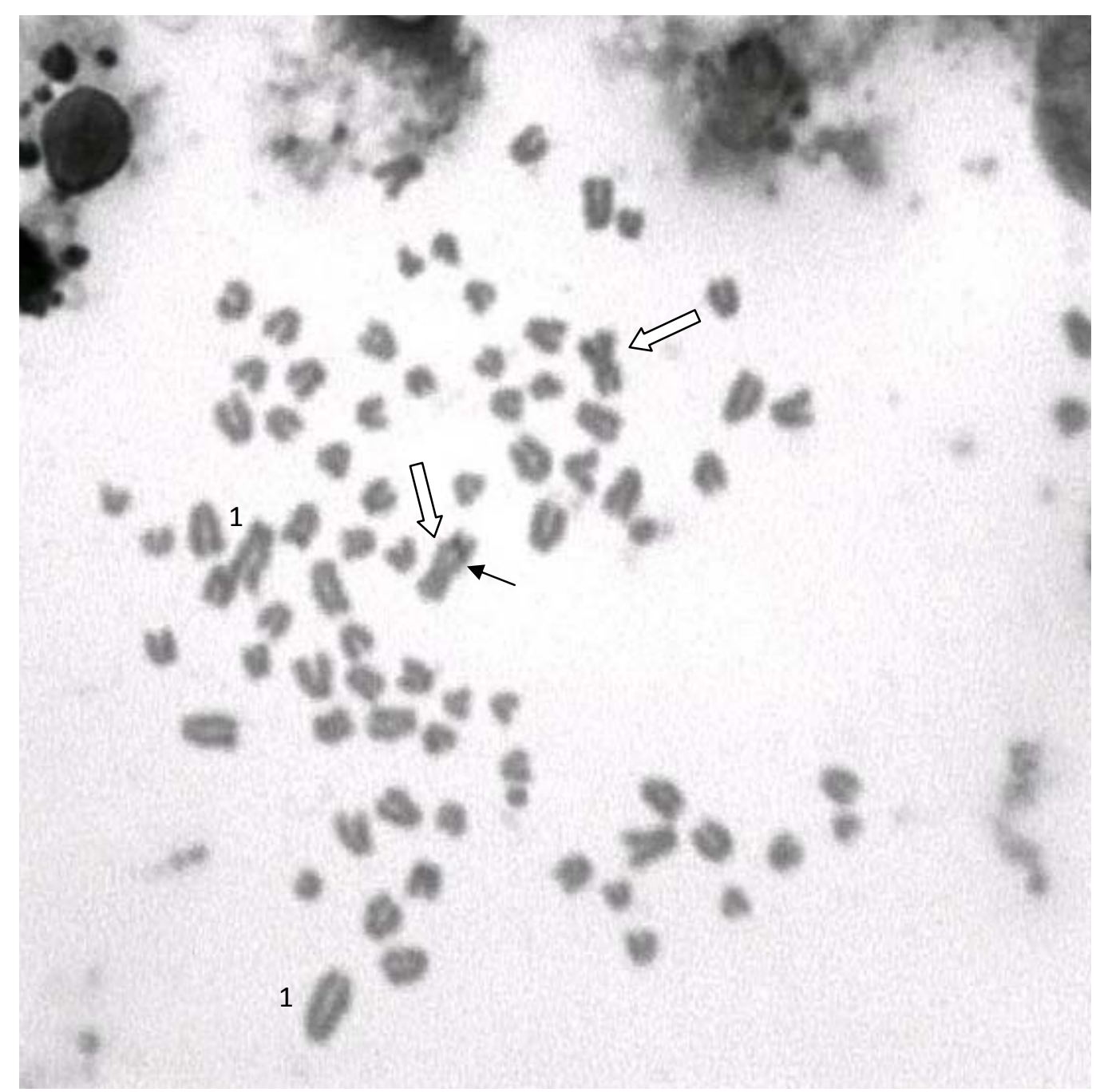

Figura 22 - Metáfase mitótica canina obtida a partir de cultura de células de tecido tumoral. Cão Boxer fêmea $(2 n=78)$. As setas largas brancas indicam o par de cromossomos sexuais $\mathrm{XX}$ e o primeiro par está indicado com o número 1 . Observação de marcação heterocromática na região distal do braço longo do cromossomo $X$ (seta simples). Coloração convencional. Visualização em microscópio Zeiss $(1000 x)$ e filtro verde 


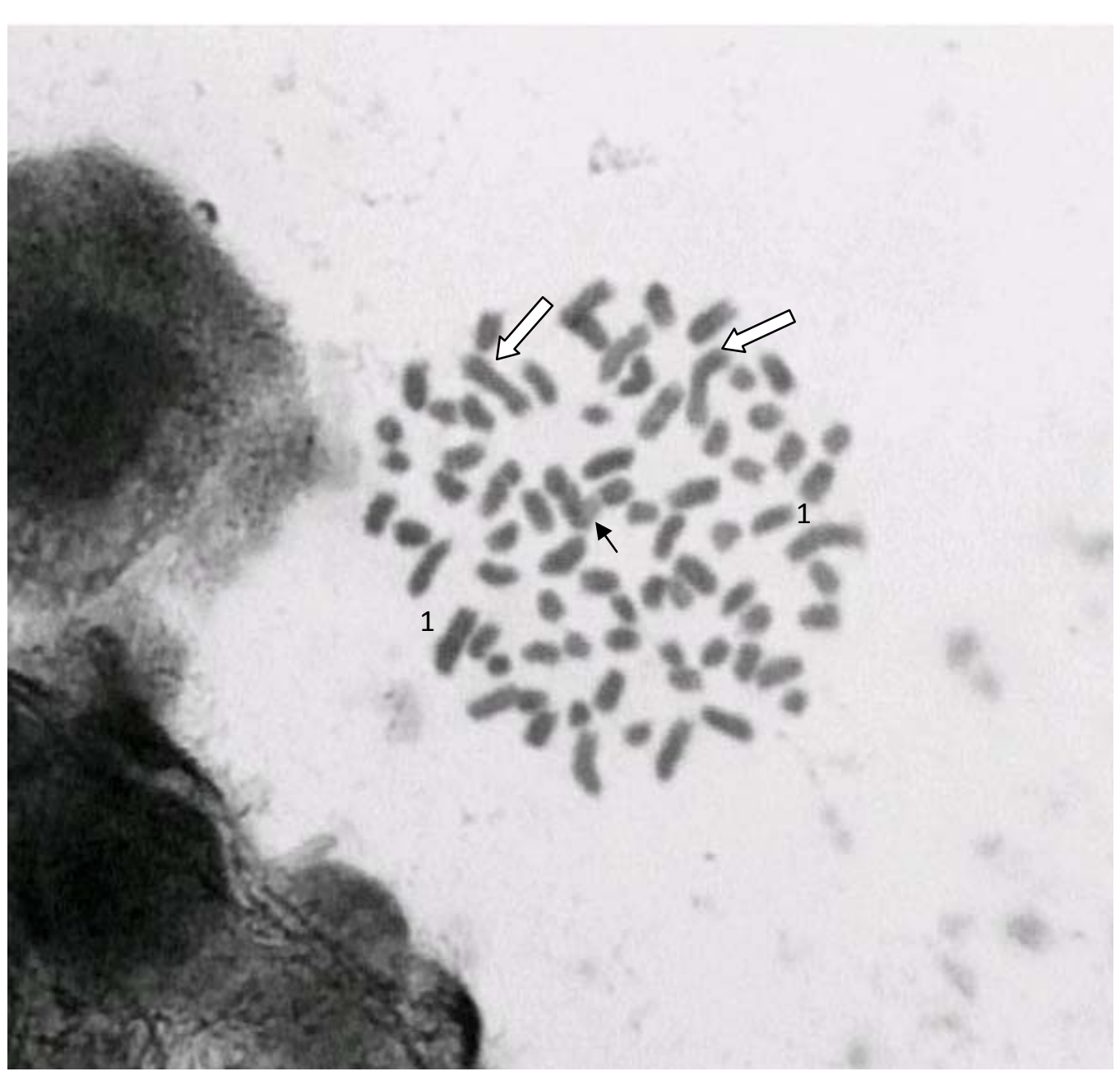

Figura 23 - Metáfase mitótica canina obtida a partir de cultura de células de tecido tumoral. Cão Boxer fêmea $(2 n=78)$. As setas largas brancas indicam o par de cromossomos sexuais $\mathrm{XX}$ e o primeiro par está indicado com o número 1 . Observação HSR (homogeneously staining region) (seta simples). Coloração convencional. Visualização em microscópio Zeiss (1000x) e filtro verde 


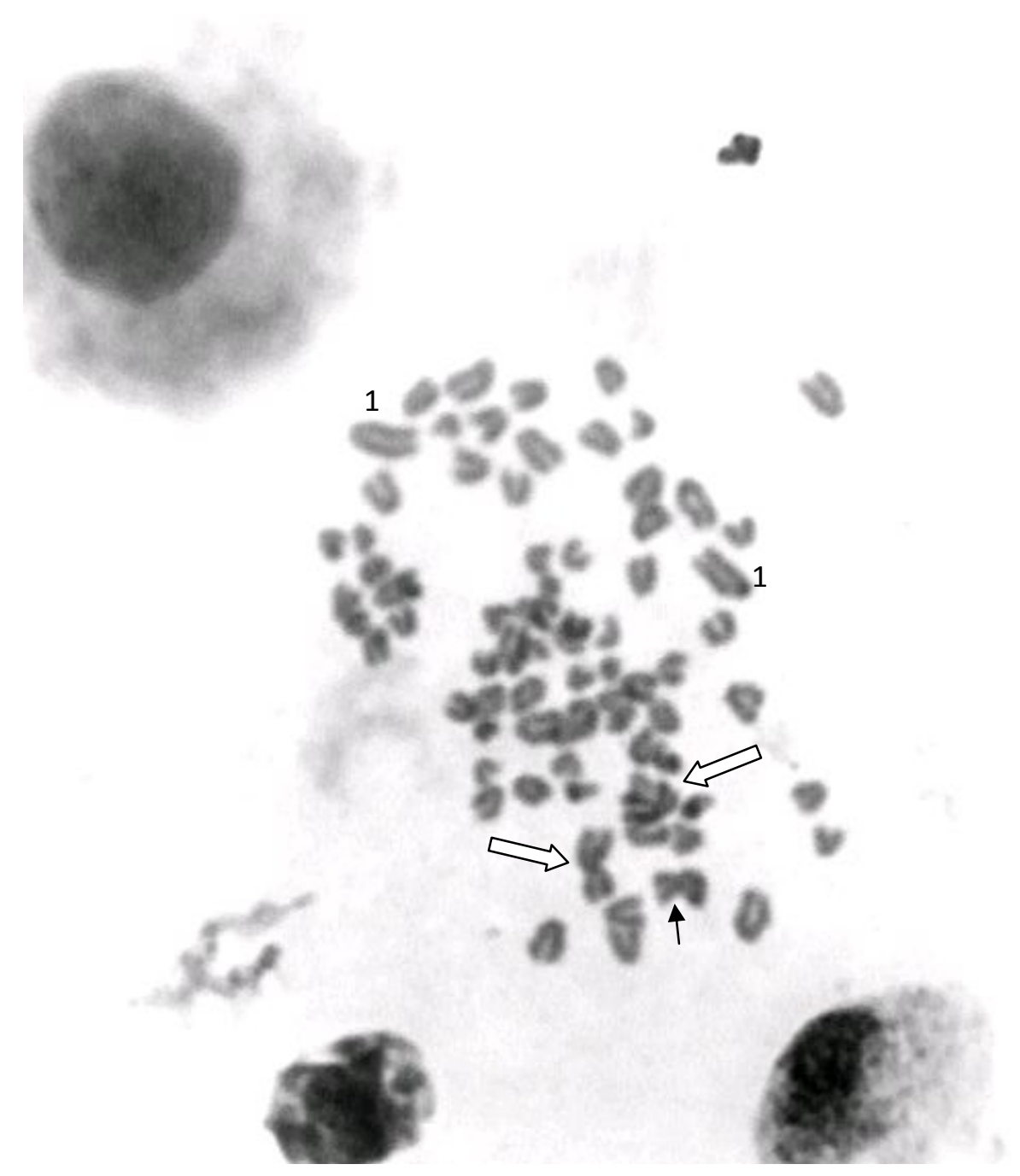

Figura 24 - Metáfase mitótica canina obtida a partir de cultura de células de tecido tumoral. Cão Boxer fêmea $(2 n=77)$. Observação de 1 cromossomo submetacêntrico mediano (seta simples), resultado de fusão cêntrica. As setas largas brancas indicam o par de cromossomos sexuais XX e o primeiro par está indicado com o número 1. Coloração convencional. Visualização em microscópio Zeiss (1000x) e filtro verde 


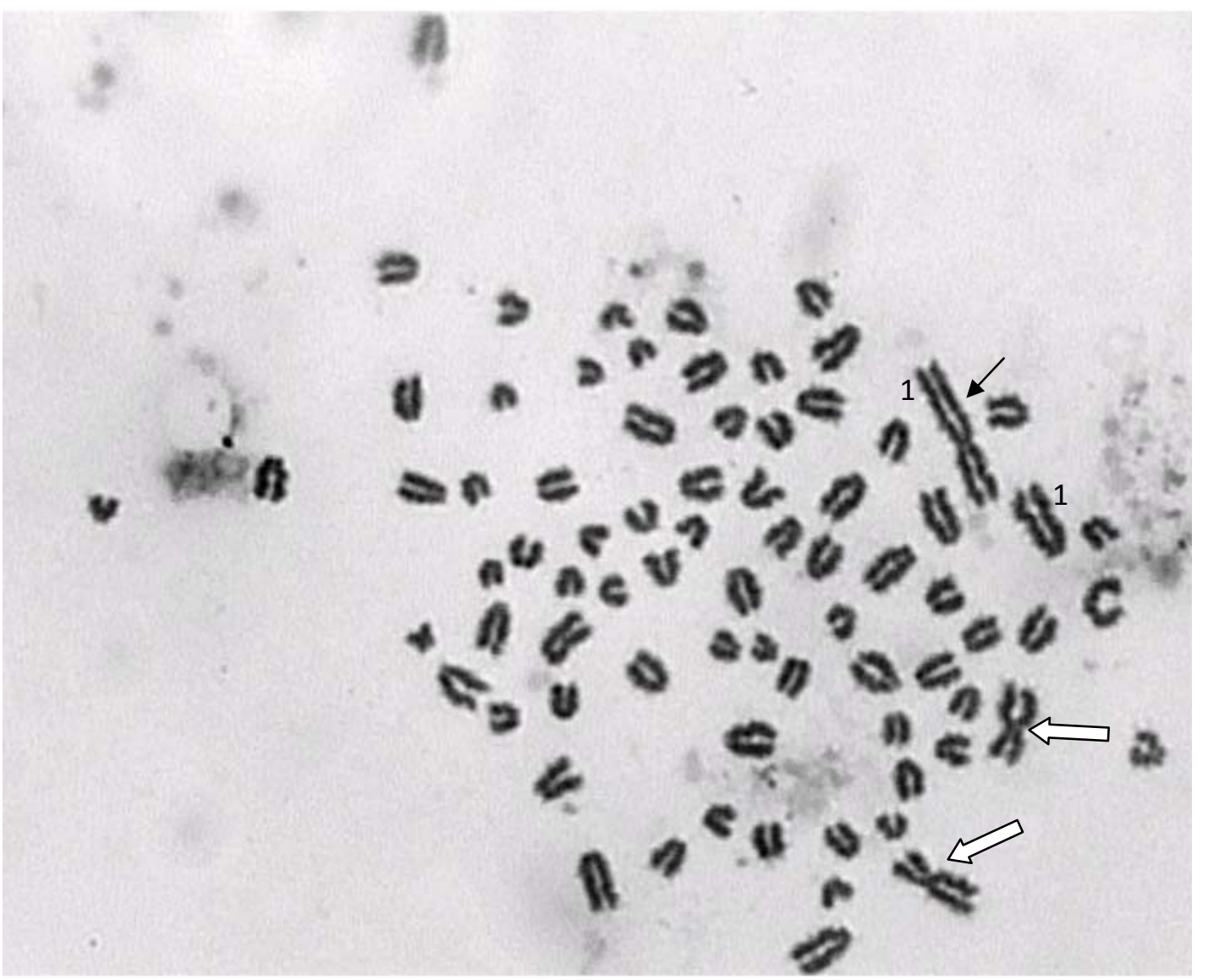

Figura 25 - Metáfase mitótica canina obtida a partir de cultura de células de tecido tumoral. Cão Boxer fêmea $(2 n=77)$. Observação de um cromossomo submetacêntrico grande (seta simples), resultado de fusão cêntrica entre um homólogo do cromossomo número $1 \mathrm{com}$ outro cromossomo acrocêntrico. As setas largas brancas indicam o par de cromossomos sexuais $X X$ e o primeiro par está indicado com o número 1. Coloração convencional. Visualização em microscópio Zeiss (1000x) e filtro verde 


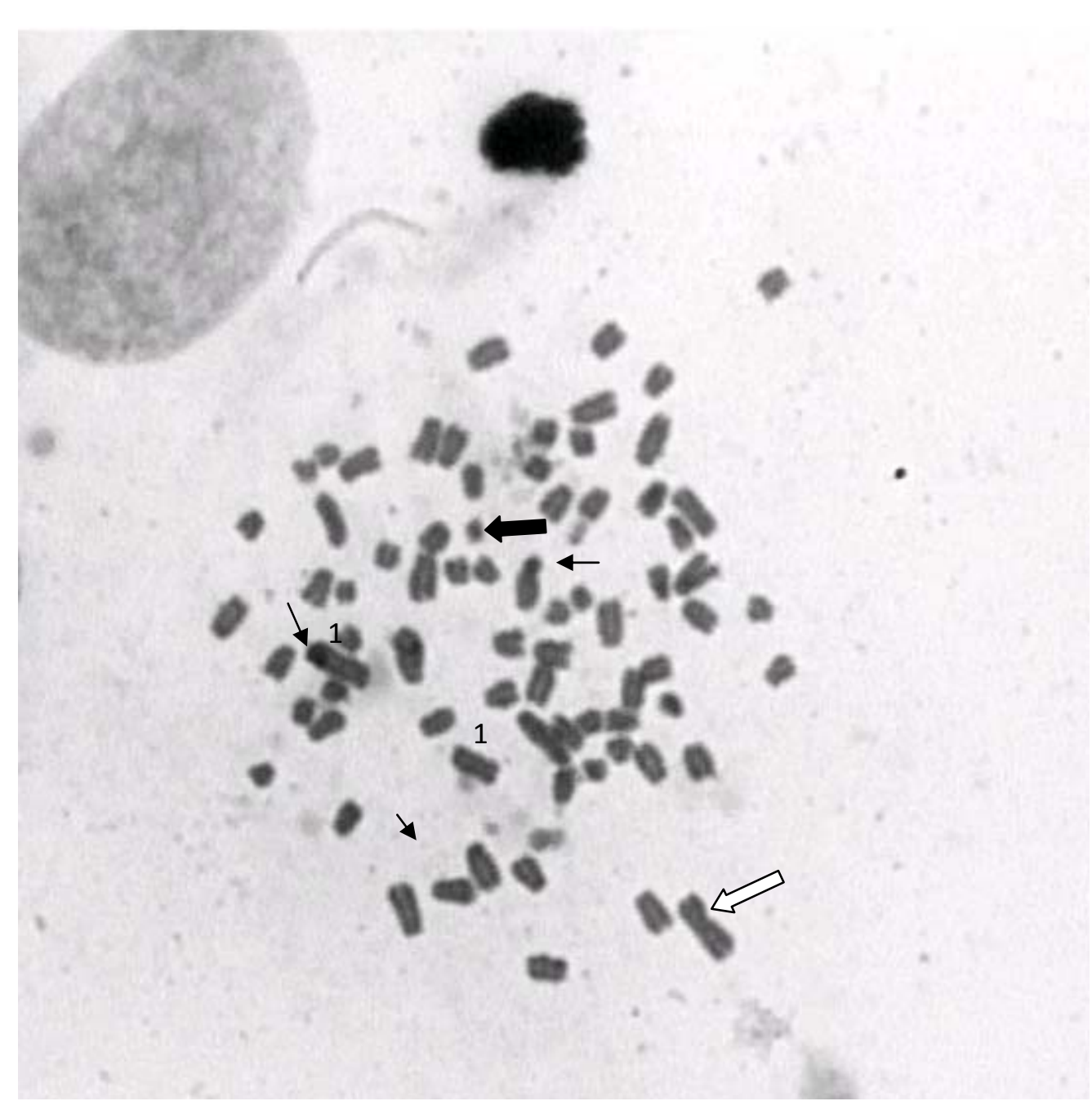

Figura 26 - Metáfase mitótica canina obtida a partir de cultura de células de tecido tumoral. Cão Boxer macho $(2 n=78)$. Observação de regiões mais coradas na região centromérica de um dos homólogos do par 1 e em outros dois cromossomos (setas simples). A seta larga branca indica o cromossomo sexual $X$ e a seta larga preta indica o cromossomo sexual $\mathrm{Y}$; o primeiro par está indicado com o número 1. Coloração convencional. Visualização em microscópio Zeiss (1000x) e filtro verde 


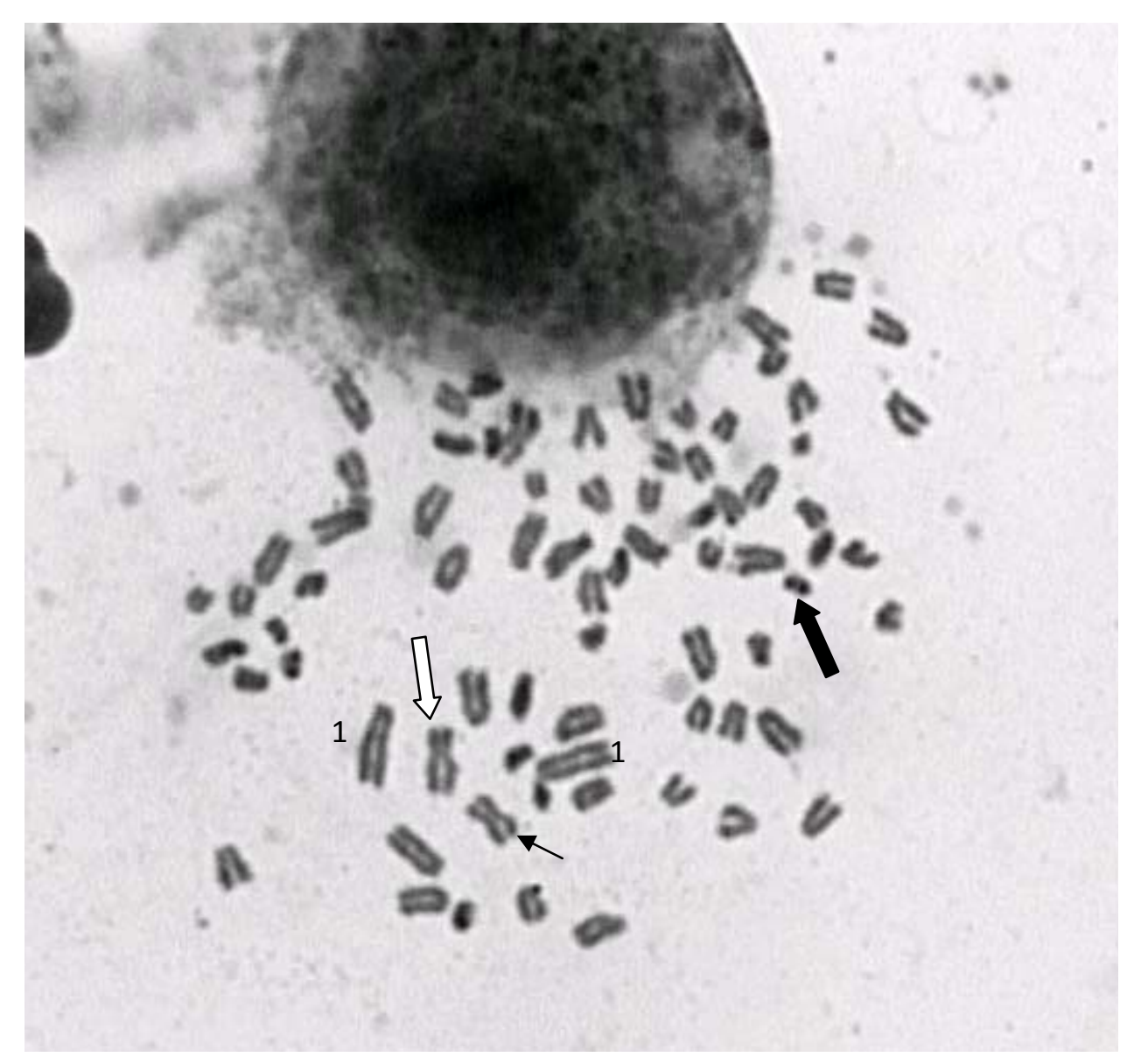

Figura 27 - Metáfase mitótica canina obtida a partir de cultura de células de tecido tumoral. Cão Boxer macho $(2 n=77)$. Observação de cromossomo submetacêntrico (seta simples) resultado de fusão cêntrica. A seta larga branca indica o cromossomo sexual $\mathrm{X}$ e a seta larga preta indica o cromossomo sexual $\mathrm{Y}$; o primeiro par está indicado com o número 1. Coloração convencional. Visualização em microscópio Zeiss (1000x) e filtro verde 


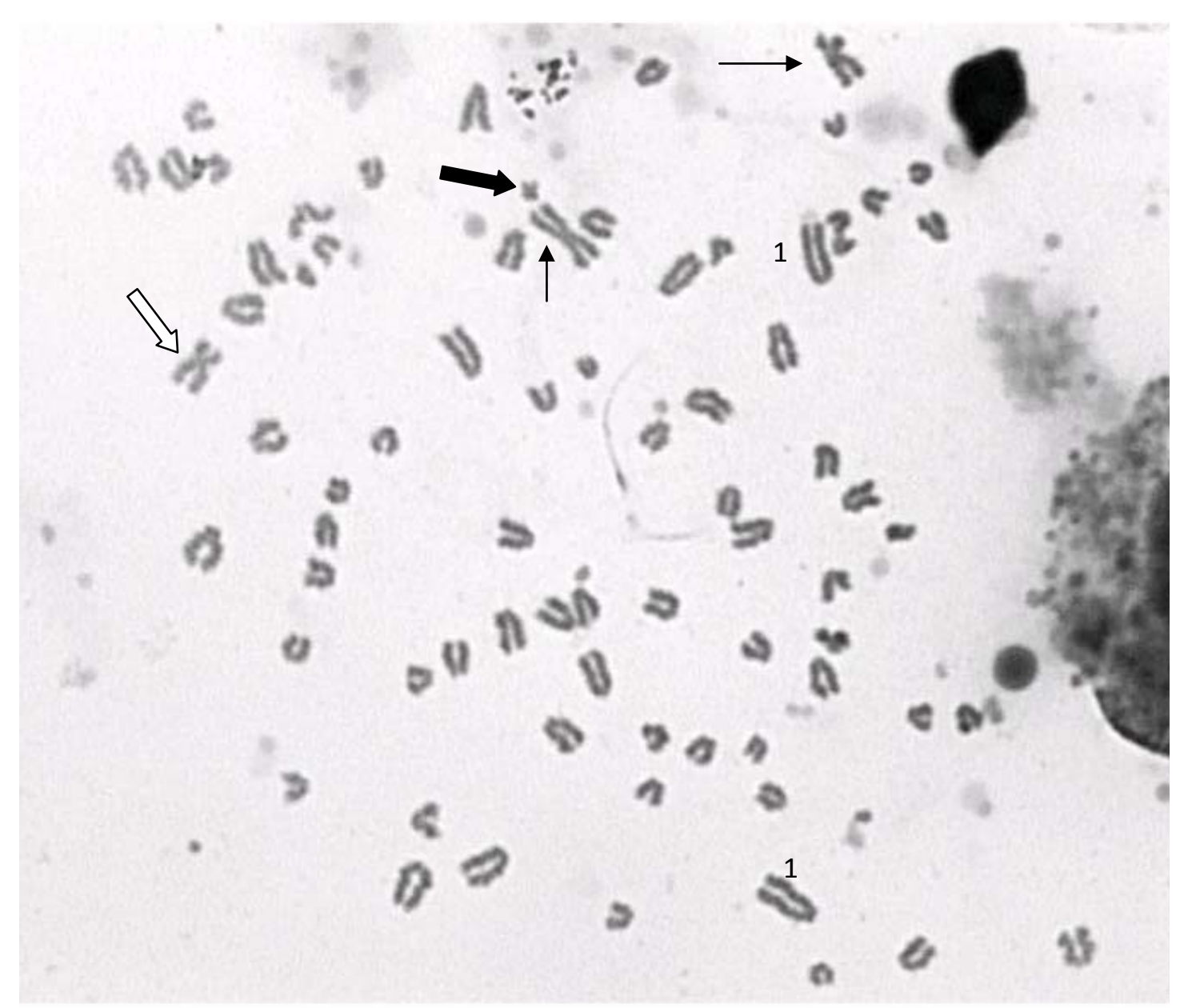

Figura 28 - Metáfase mitótica canina obtida a partir de cultura de células de tecido tumoral. Cão Boxer macho $(2 n=76)$. Observação de dois cromossomos submetacêntricos (setas simples) resultados de fusão cêntrica. A seta larga branca indica o cromossomo sexual $\mathrm{X}$ e a seta larga preta indica o cromossomo sexual $\mathrm{Y}$; o primeiro par está indicado com o número 1. Coloração convencional. Visualização em microscópio Zeiss (1000x) e filtro verde 


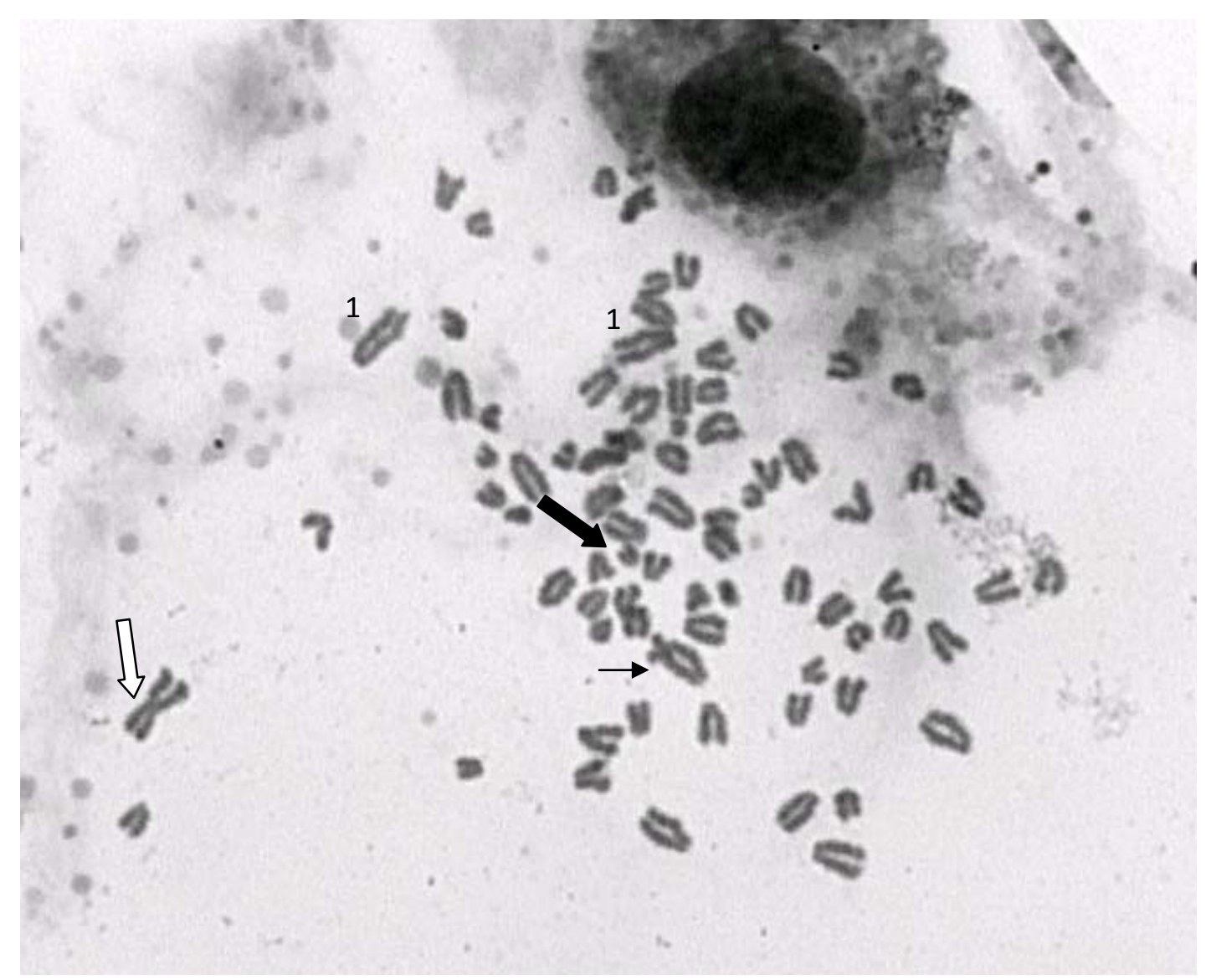

Figura 29 - Metáfase mitótica canina obtida a partir de cultura de células de tecido tumoral. Cão Boxer macho $(2 n=77)$. Observação de um cromossomo submetacêntrico (seta simples) resultado de fusão cêntrica. A seta larga branca indica o cromossomo sexual $\mathrm{X}$ e a seta larga preta indica o cromossomo sexual $\mathrm{Y}$; 0 primeiro par está indicado com o número 1. Coloração convencional. Visualização em microscópio Zeiss (1000x) e filtro verde 


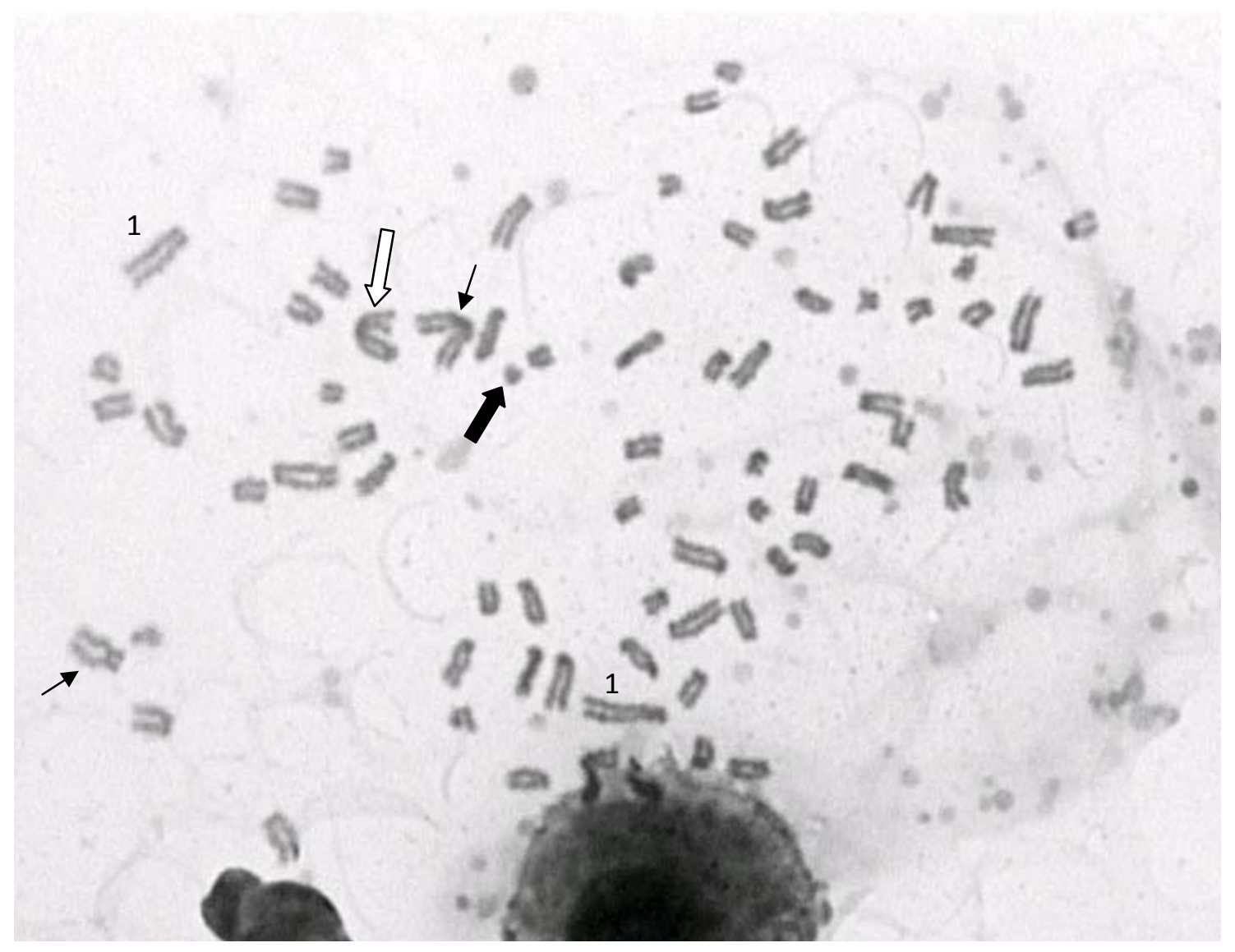

Figura 30 - Metáfase mitótica canina obtida a partir de cultura de células de tecido tumoral. Cão Boxer macho $(2 \mathrm{n}=76)$. Observação de dois cromossomos submetacêntricos (setas simples) resultados de fusões cêntricas. Observado também maior absorção de corante nos centrômeros de alguns cromossomos. A seta larga branca indica o cromossomo sexual $X$ e a seta larga preta indica o cromossomo sexual Y; o primeiro par está indicado com o número 1. Coloração convencional. Visualização em microscópio Zeiss (1000x) e filtro verde 


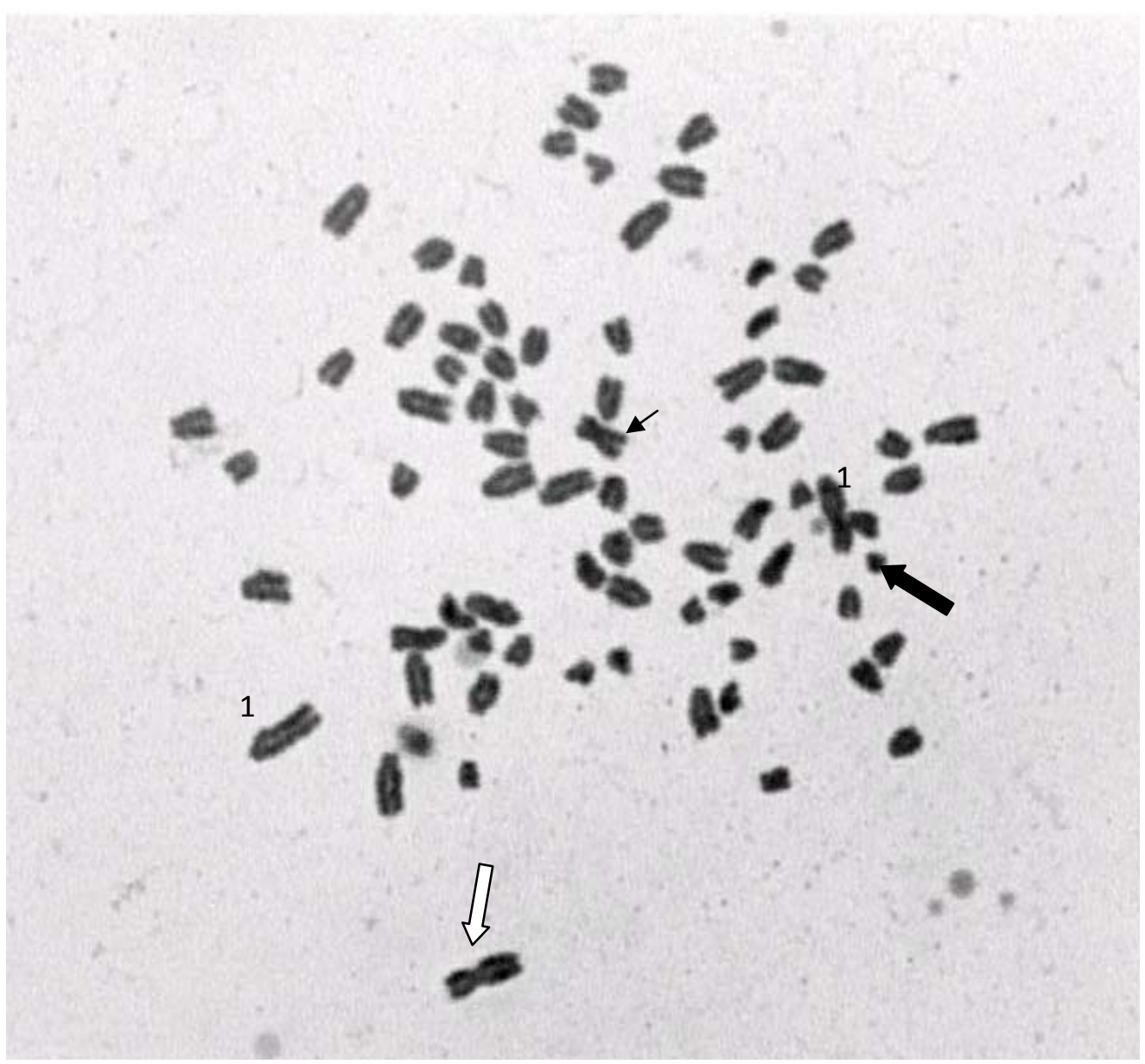

Figura 31 - Metáfase mitótica canina obtida a partir de cultura de células de tecido tumoral. Cão Boxer macho $(2 n=77)$. Observação de um cromossomo submetacêntrico (seta simples) resultado de fusão cêntrica. A seta larga branca indica o cromossomo sexual $X$ e a seta larga preta indica o cromossomo sexual $Y$; o primeiro par está indicado com o número 1. Coloração convencional. Visualização em microscópio Zeiss (1000x) e filtro verde 


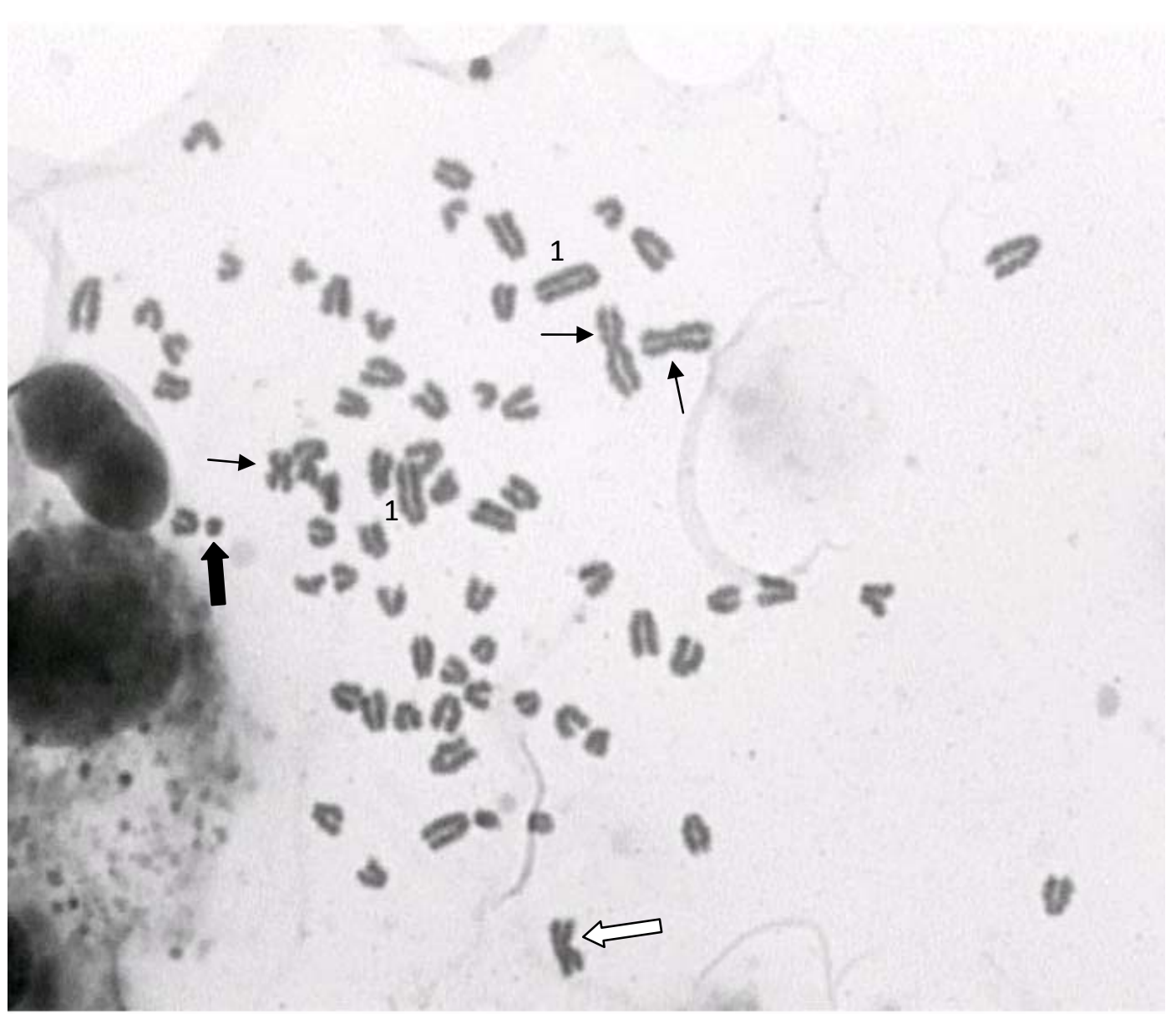

Figura 32 - Metáfase mitótica canina obtida a partir de cultura de células de tecido tumoral. Cão Boxer macho $(2 n=75)$. Observação de dois cromossomos metacêntricos (um médio e um pequeno) e um submetacêntrico grande (setas simples) resultados de fusões cêntricas. A seta larga branca indica o cromossomo sexual $X$ e a seta larga preta indica o cromossomo sexual Y; o primeiro par está indicado com o número 1. Coloração convencional. Visualização em microscópio Zeiss (1000x) e filtro verde 


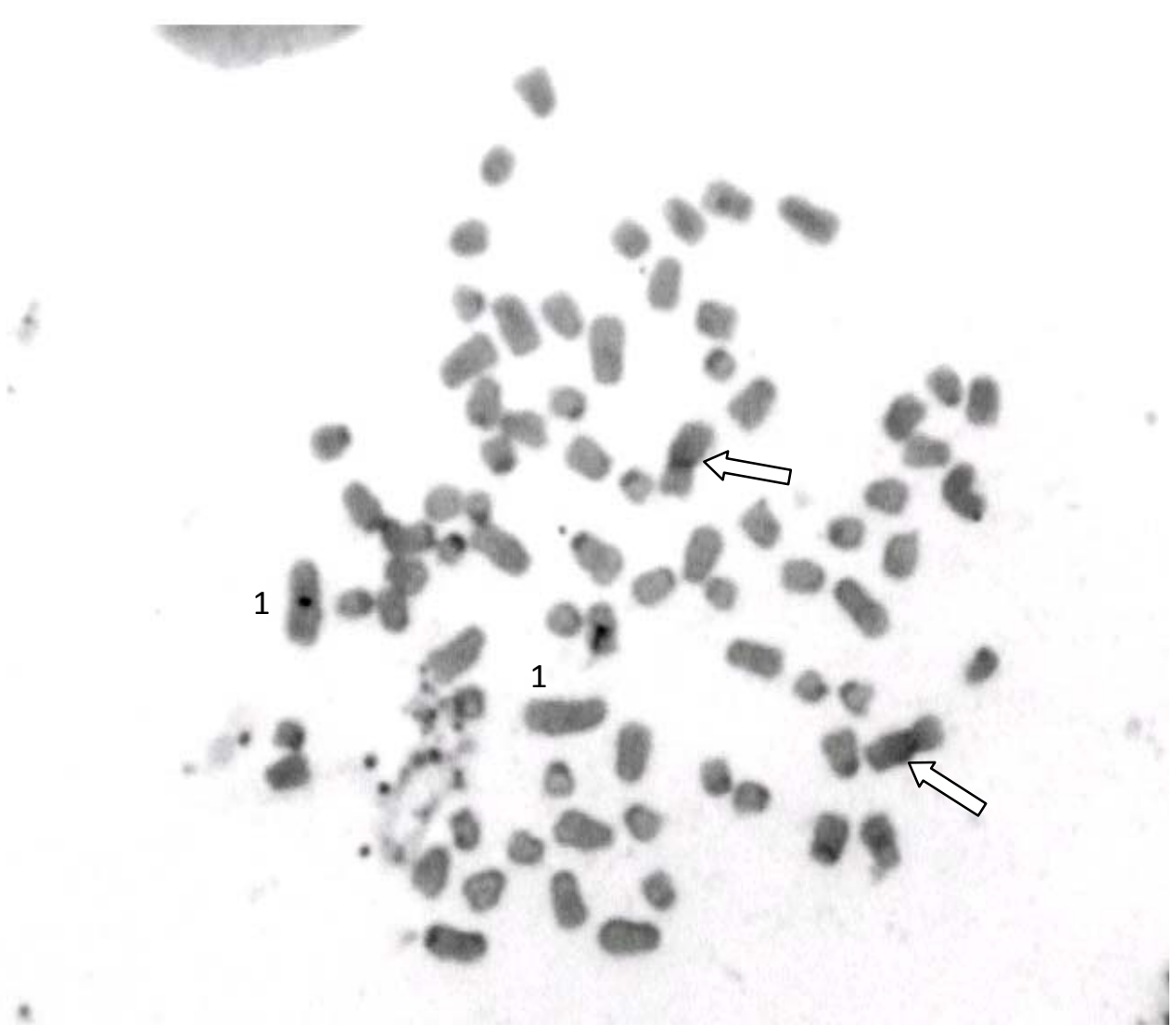

Figura 33 - Metáfase mitótica canina obtida a partir de cultura de células de tecido tumoral. Cão Boxer fêmea $(2 n=78)$. Indicados: par sexual (setas largas brancas) e par número 1. Coloração Banda C. Visualização em microscópio Zeiss (1000x) e filtro verde 


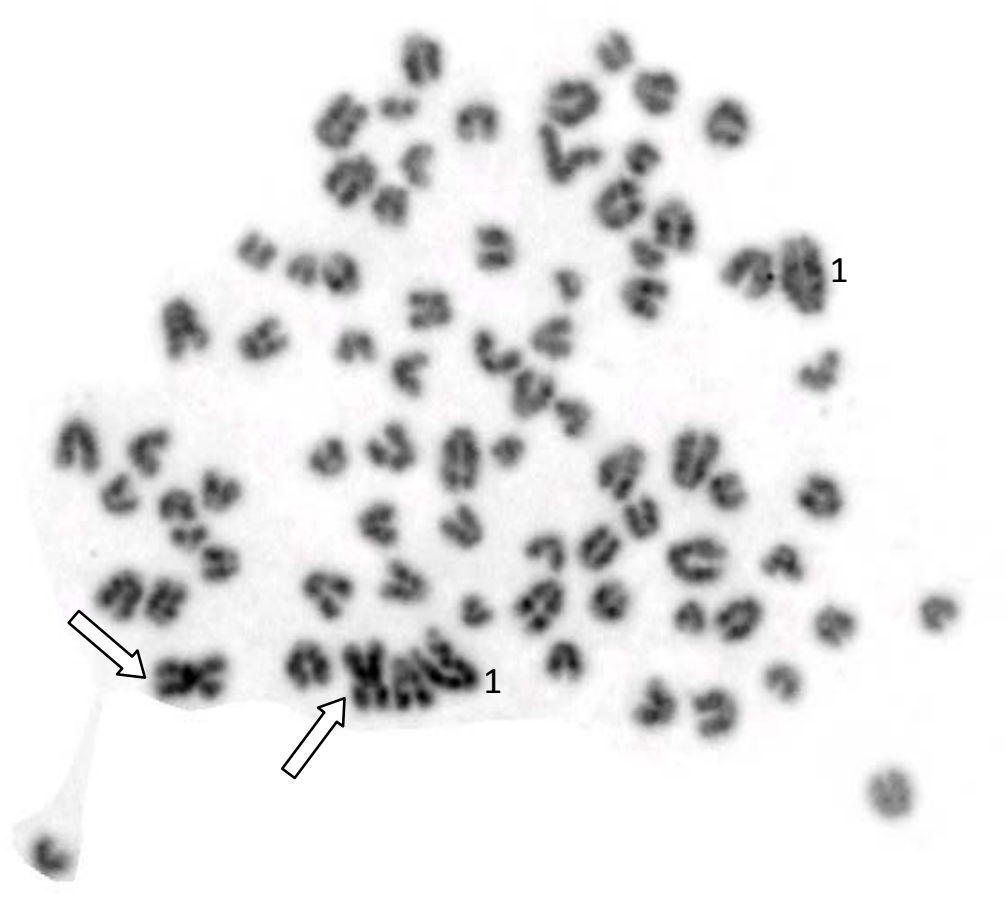

Figura 34 - Metáfase de tecido tumoral. Cão Boxer fêmea $(2 n=78)$. Observação $H S R$ (homogeneously staining region) (seta simples). Indicados: par sexual (setas largas brancas) e par homólogo número 1. Coloração Banda G. Visualização em microscópio Zeiss (1000x) e filtro verde 


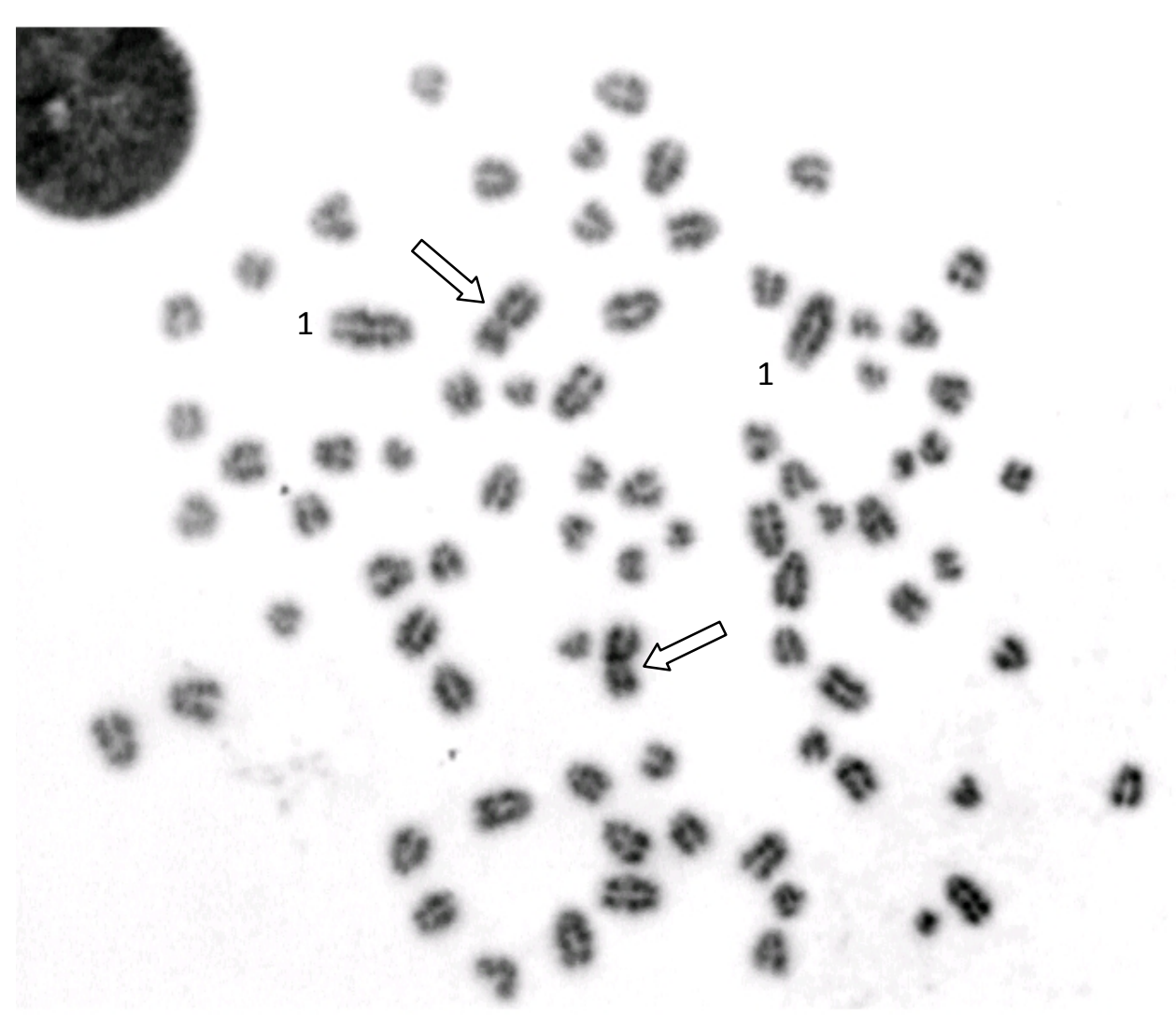

Figura 35 - Metáfase mitótica canina obtida a partir de cultura de linfócitos periféricos. Cão Boxer fêmea $(2 n=78)$. As setas largas brancas indicam o par de cromossomos sexuais $\mathrm{XX}$ e o primeiro par está identificado com o número 1. Coloração Banda G. Visualização em microscópio Zeiss (1000x) e filtro verde 


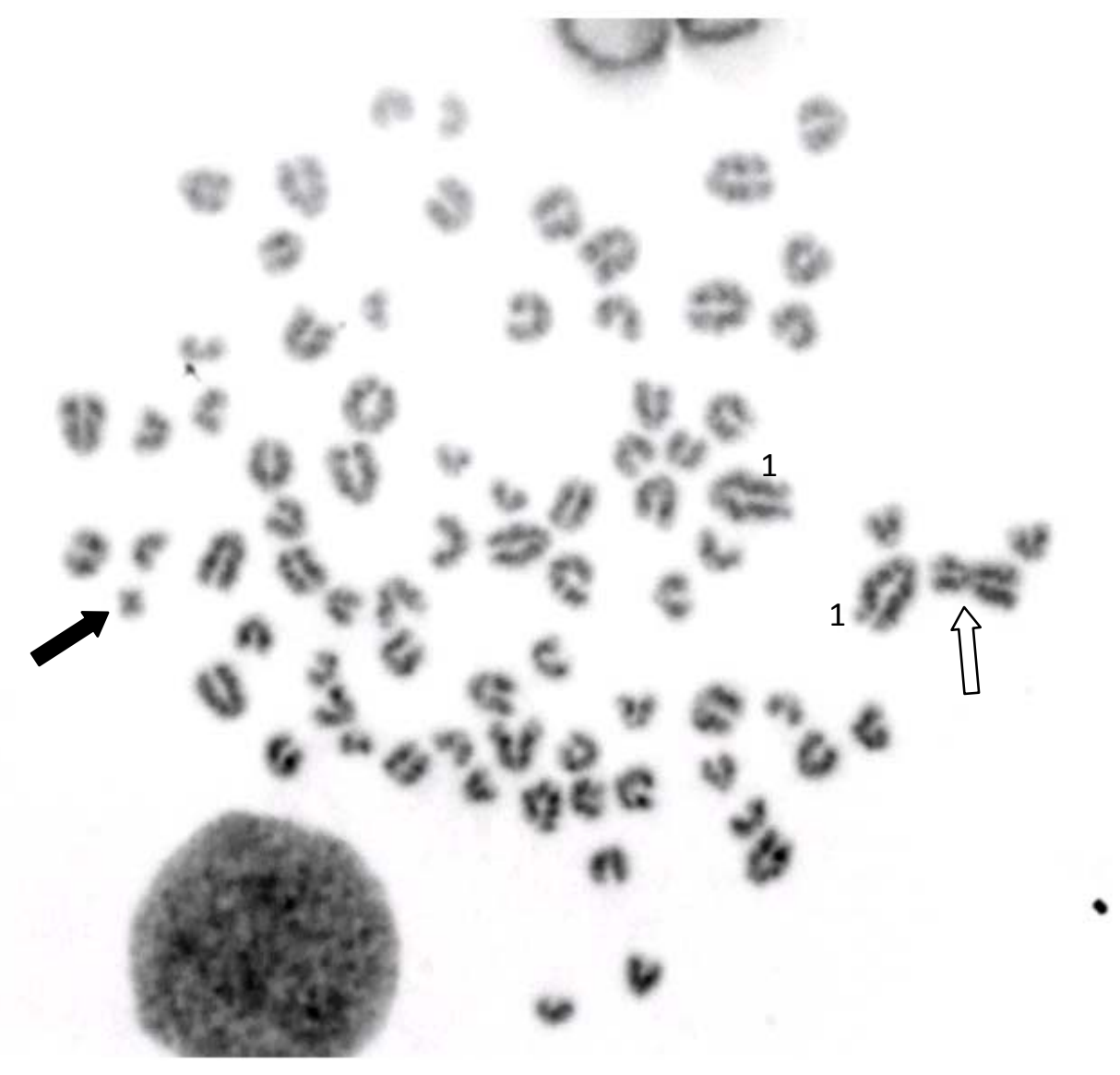

Figura 36 - Metáfase mitótica canina obtida a partir de cultura de linfócitos periféricos. Cão Boxer macho $(2 n=78)$. A seta larga branca indica o cromossomo sexual $X e$ a seta larga preta indica o cromossomo sexual $\mathrm{Y}$; o primeiro par está indicado com o número 1. Coloração Banda G. Visualização em microscópio Zeiss $(1000 x)$ e filtro verde 


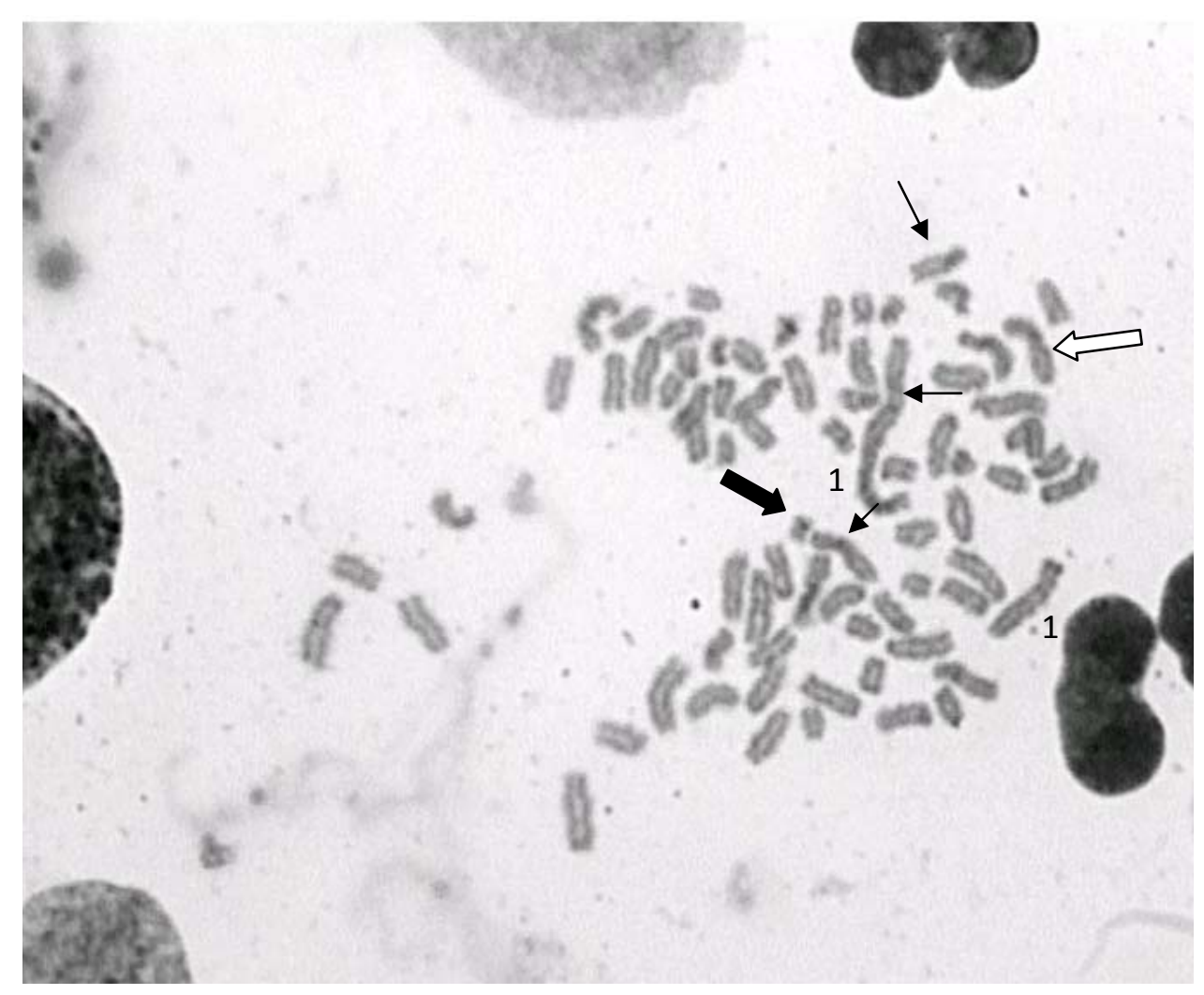

Figura 37 - Metáfase de tecido tumoral. Cão Boxer macho $(2 n=75)$. Observação de três cromossomos submetacêntricos (setas simples) devido a fusões cêntricas. Um dos homólogos do par 1 está envolvido no rearranjo do maior cromossomo submetacêntrico encontrado. A seta larga branca indica o cromossomo sexual $X$ e a seta larga preta indica o cromossomo sexual Y; o primeiro par está indicado com o número 1. Coloração convencional. Visualização em microscópio Zeiss (1000x) e filtro verde 


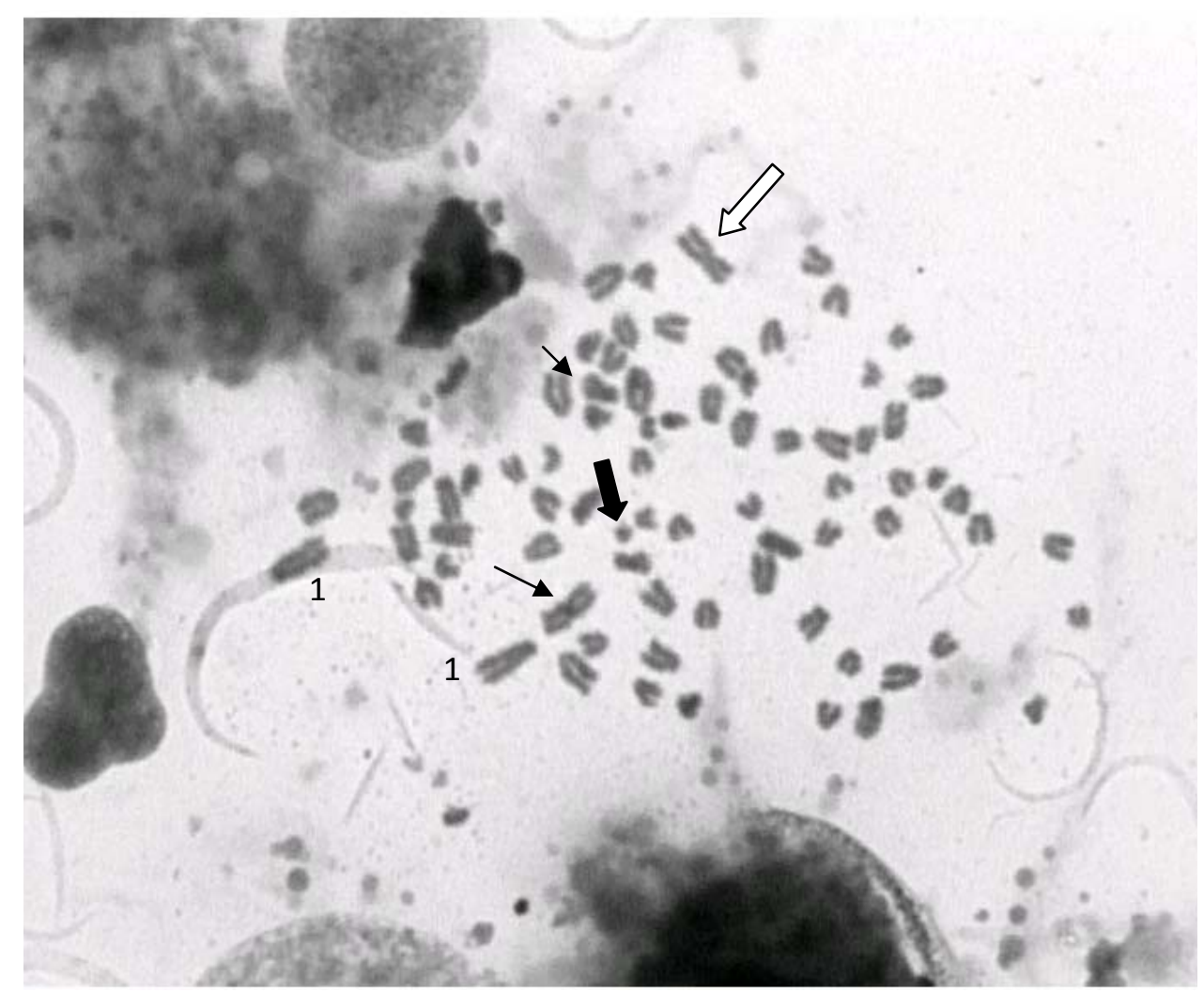

Figura 38 - Metáfase de tecido tumoral. Cão Boxer macho $(2 n=76)$. Observação de um cromossomo metacêntrico grande e um submetacêntrico pequeno (setas simples) resultado de fusões cêntricas. A seta larga branca indica o cromossomo sexual $\mathrm{X}$ e a seta larga preta indica o cromossomo sexual $\mathrm{Y}$; o primeiro par está indicado com o número 1. Coloração convencional. Visualização em microscópio Zeiss (1000x) e filtro verde 


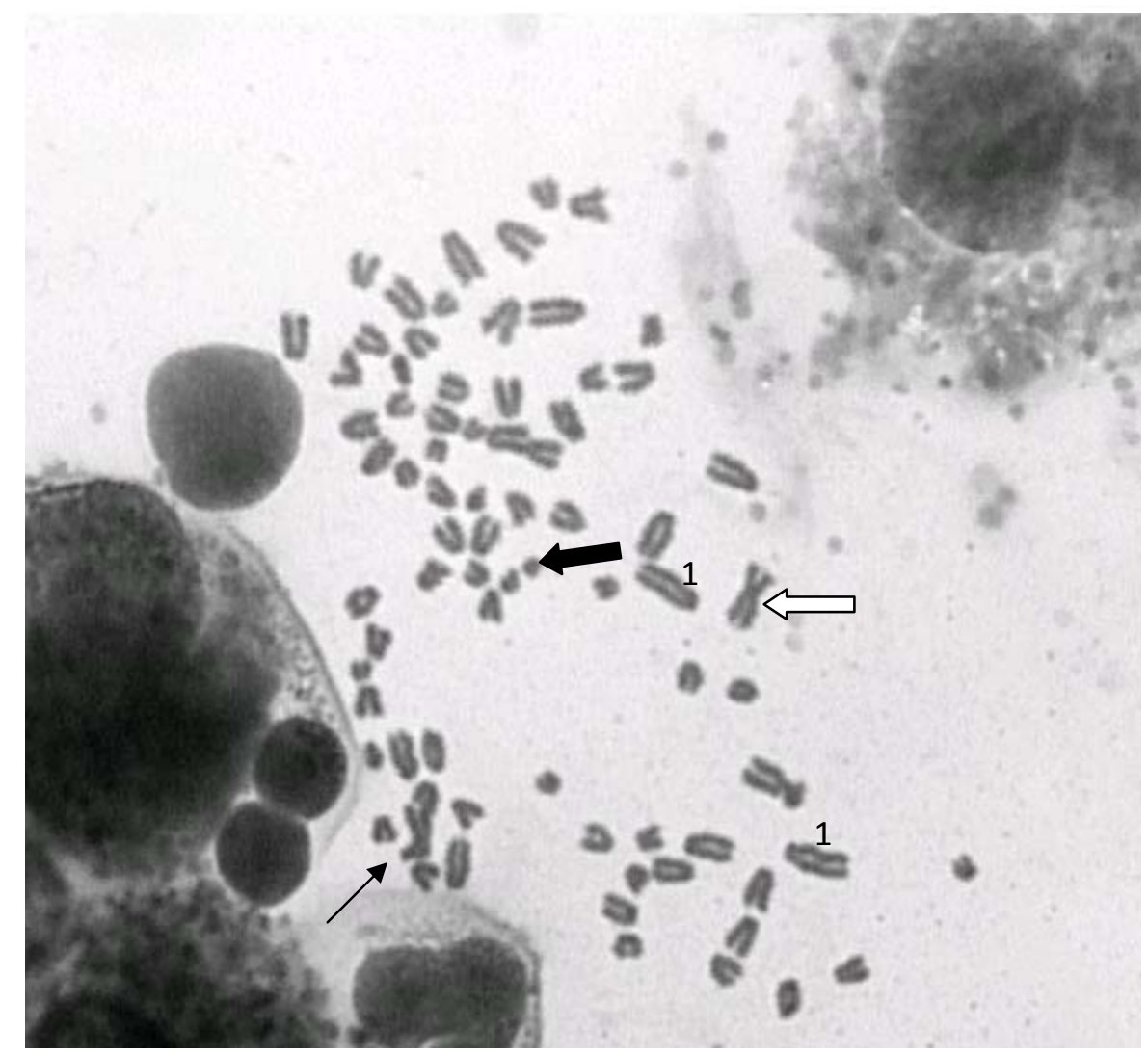

Figura 39 - Metáfase de tecido tumoral. Cão Boxer macho $(2 n=77)$. Observação de um cromossomo submetacêntrico grande (setas simples) resultado de fusões cêntricas. A seta larga branca indica o cromossomo sexual $X$ e a seta larga preta indica o cromossomo sexual $\mathrm{Y}$; o primeiro par está indicado com o número 1. Coloração convencional. Visualização em microscópio Zeiss (1000x) e filtro verde 


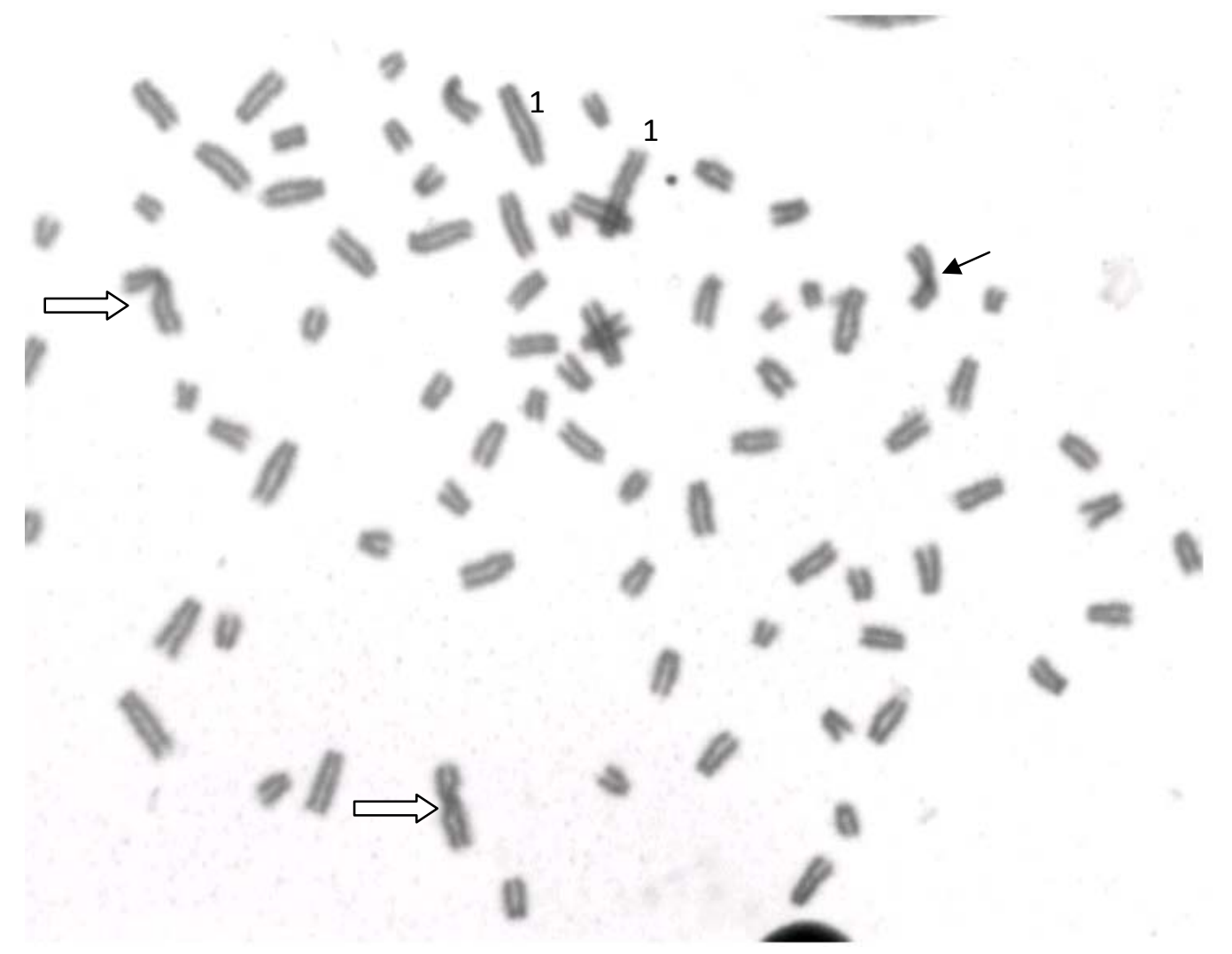

Figura 40 - Metáfase de tecido tumoral. Cão Boxer fêmea $(2 n=77)$. Observação de 1 cromossomo submetacêntrico (seta simples) al. Indicados: par sexual (setas largas brancas) e par homólogo número 1. Coloração convencional. Visualização em microscópio Zeiss (1000x) e filtro verde 


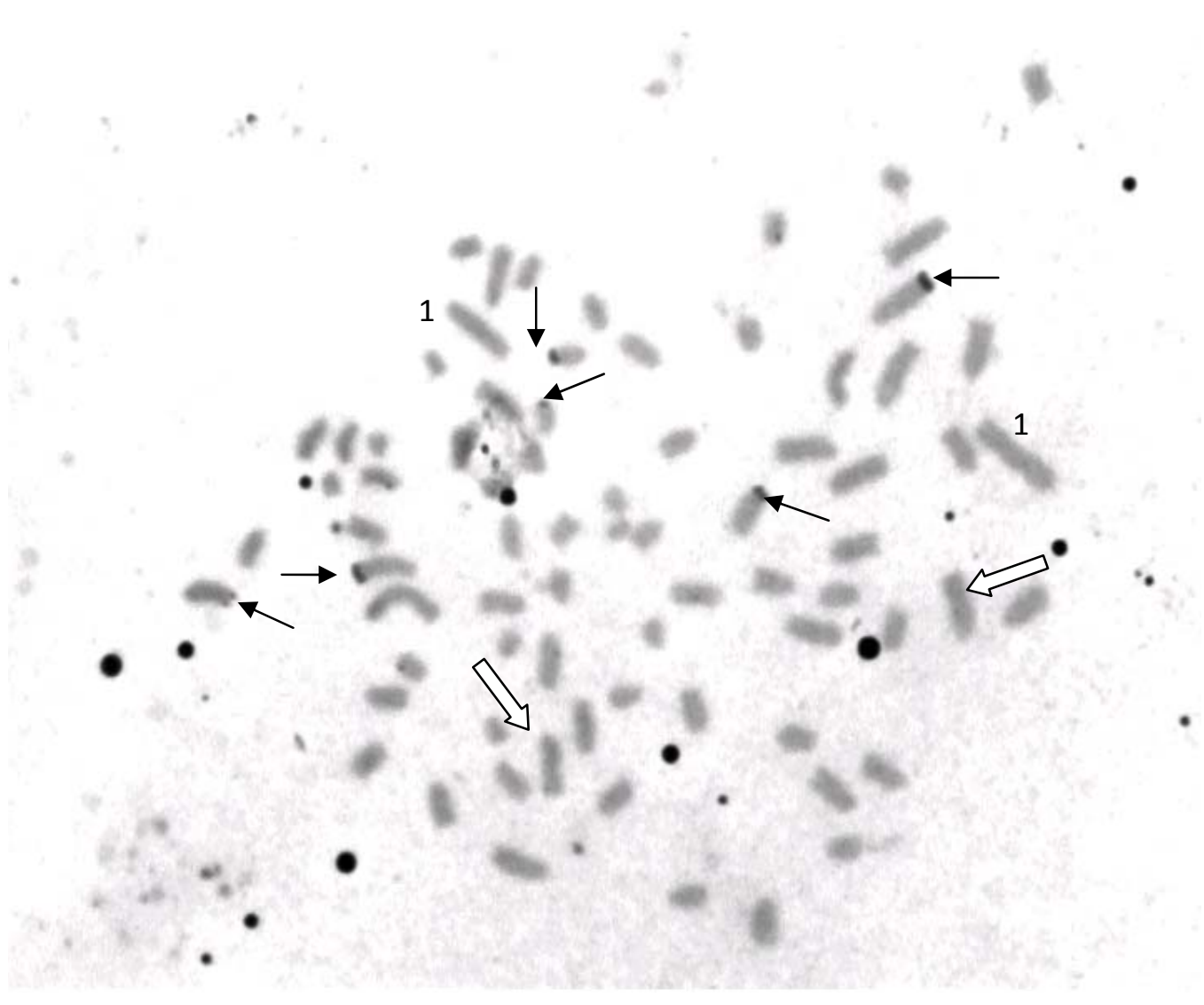

Figura 41 - Metáfase de tecido tumoral. Cão Boxer fêmea $(2 n=78)$. Observação de marcação pela prata na região telomérica de seis cromossomos (setas simples). Indicados: 1 homólogo sexual (seta larga branca) e par número 1. Coloração por nitrato de prata (Banda Ron). Visualização em microscópio Zeiss (1000x) e filtro verde 


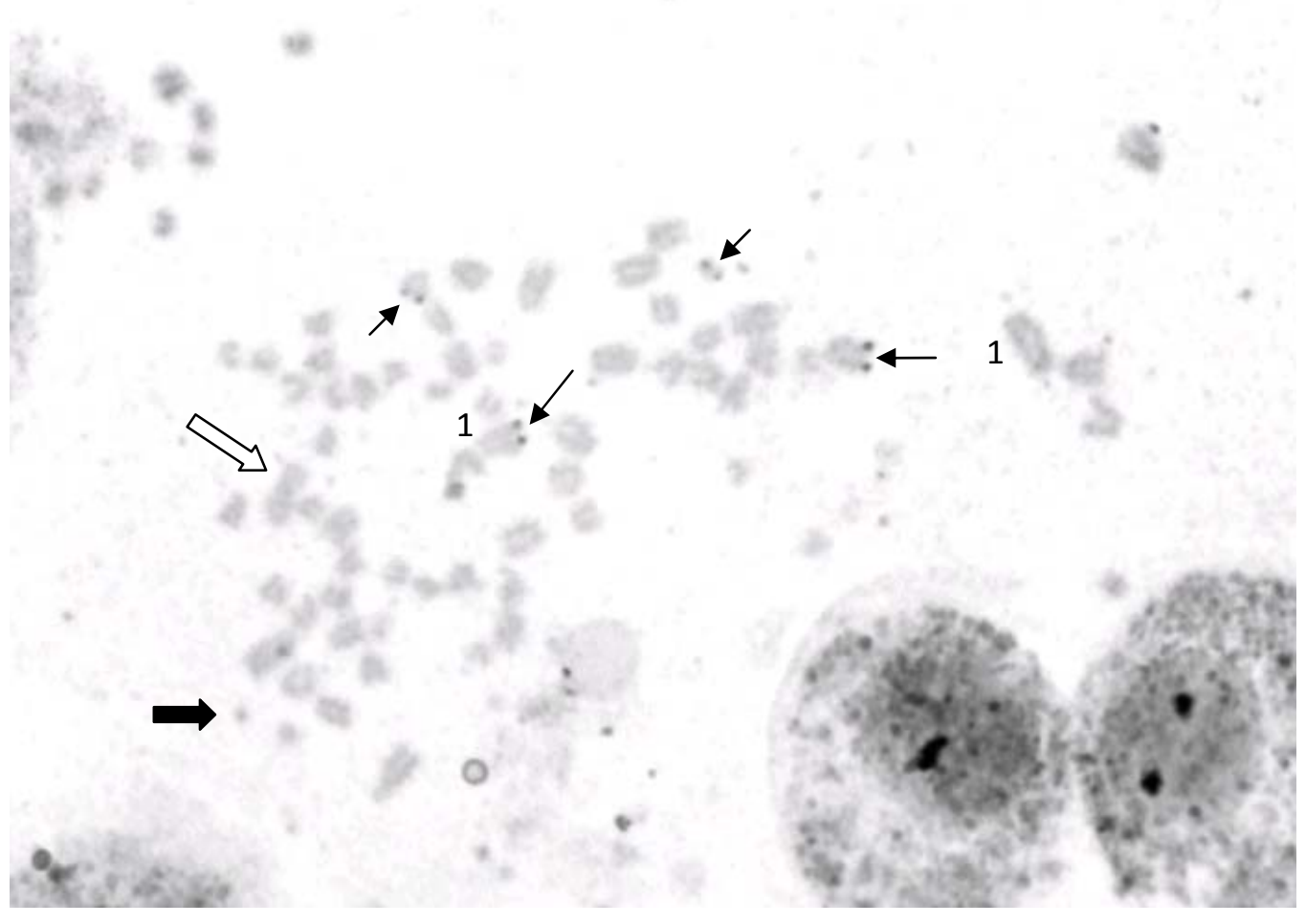

Figura 42 - Metáfase de tecido tumoral. Cão Boxer macho $(2 n=78)$. Observação de marcação pela prata na região telomérica em quatro cromossomos (setas simples). A seta larga branca indica o cromossomo sexual $X$ e a seta larga preta indica o cromossomo sexual $\mathrm{Y}$; o primeiro par está indicado com o número 1. Coloração por nitrato de prata (Banda Ron). Visualização em microscópio Zeiss (1000x) e filtro verde 


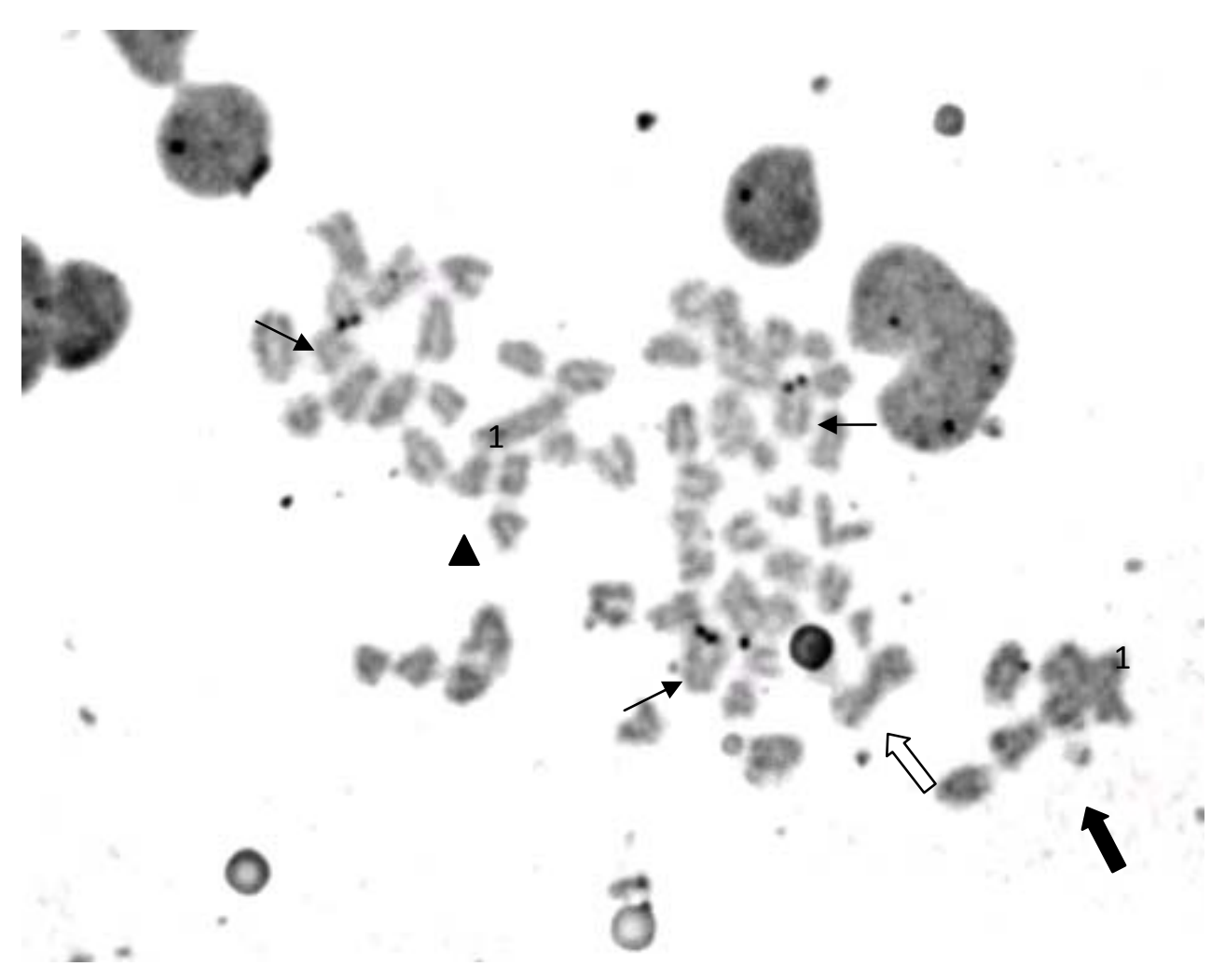

Figura 43 - Metáfase de tecido tumoral. Cão Boxer macho $(2 n=77)$. Observação de um cromossomo submetacêntrico (triângulo) e de marcação pela prata na região telomérica em três cromossomos (setas simples). A seta larga branca indica o cromossomo sexual $\mathrm{X}$ e a seta larga preta indica o cromossomo sexual $\mathrm{Y}$; o primeiro par está indicado com o número 1. Coloração por nitrato de prata (Banda Ron). Visualização em microscópio Zeiss (1000x) e filtro verde 


\section{Discussão}

\section{Discussão}

Os resultados do estudo retrospectivo realizado sobre a incidência de mastocitomas em cães no período entre julho de 1999 e julho de 2003, realizado no Serviço de Patologia do HOVET - FMVZ - USP, mostraram que 2,3\% dos laudos (94) eram relacionados aos casos de mastocitomas em cães, dos quais 53 animais $(56,4 \%)$ eram machos. A idade variou entre um e 15 anos, com média de $8,13 \pm$ 3,$02 ; 58,6 \%$ dos cães apresentaram-se na faixa etária entre sete e dez anos. Esses dados corroboram com os resultados de em estudo realizado por Vail (1996), que apresentou incidência de mastocitomas principalmente em cães com idade média de 8-9 anos.

Ainda, os resultados do estudo retrospectivo realizado no Serviço de Patologia do HOVET - FMVZ - USP, indicaram maior prevalência de mastocitomas em animais sem raça definida $(37,2 \%)$, Boxer $(27,7 \%)$ e Poodle $(7,4 \%)$, o que coincide com relatos de que a predisposição racial envolve, na grande maioria, cães sem raça definida, mas também acomete as raças Boxer, Boston Terrier, Buldogue Inglês, Bull Terrier Inglês, Beagle, Labrador e Schanauzer (VAIL 1996, O’KEEFE 2003).

De acordo com a classificação de Patnaik (1984), 16\% dos tumores apresentaram grau I, 26,6\% grau II, 16\% grau III e 4,3\% apresentaram graus II e III no mesmo animal. Patnaik (1984) apresentou incidência de mastocitomas com relação à graduação sendo $36 \%$ classificados como grau I, $43 \%$ grau II e $20 \%$ grau III.

Também foi realizado um estudo comparativo para avaliação numérica dos cromossomos, onde foram analisadas amostras de sangue e massa tumoral em cinco cães, dentre as raças Boxer, Pug, Labrador e dois cães sem raça definida. Na análise realizada, a contagem cromossômica no sangue apresentou número habitual $(2 n=78)$, no entanto, houve variação entre 74 e 79 cromossomos no tumor. Estes 


\section{Discussão}

resultados corroboram com estudos realizados em TVT canino, onde o cariótipo apresentou variação numérica entre 57 e 64 cromossomos (COHEN, 1978).

Através do levantamento de dados de exames histopatológicos realizados pelo Serviço de Patologia Animal do HOVET - FMVZ - USP, no período compreendido entre agosto de 2004 e abril de 2008, foram registrados 206 casos de mastocitomas em cães. No que se refere à raça, 31\% dos casos ocorreram em animais Boxer, seguidos de $24 \%$ de animais sem raça definida, $8 \%$ de Labradores e o restante correspondente ao total das outras raças (37\%), dados estes que também confirmados por estudos prévios (VAIL 1996, O'KEEFE 2003).

A idade dos cães variou entre 3 e 15 anos, com prevalência de $42 \%$ dos animais com faixa etária entre 7 e 10 anos, o que coincide com dados relatados em literatura.

Com relação à citogenética, foram encontradas alterações numéricas e estruturais nas análises realizadas nos cromossomos em metáfase mitóticos dos três animais da raça Boxer.

Entre as aberrações cromossômicas, foram encontradas cromossomos metacêntricos e submetacêntricos, assim como HSR. A presença de cromossomos metacêntricos e submetacêntricos, além dos cromossomos sexuais, indica a ocorrência de fusões cêntricas de cromossomos acrocêntricos.

$\mathrm{Na}$ análise das metáfases de células tumorais, entre todas as colorações, foram observadas as primeiras alterações. Dentre as 352 metáfases analisadas, $70,9 \%$ apresentou número diplóide normal, $2 n=78$. Outros $17,4 \%$ das metáfases mostraram $2 n=77 ; 9,8 \%$ tinham $2 n=76$. Cinco metáfases $(1,3 \%)$ apresentaram $2 n=79$ e duas células apresentaram $2 n=75$.

Alguns estudos realizados com neoplasias relataram alterações numéricas e estruturais em cariótipo canino, como um estudo já realizado com mastocitomas por Stone et al. (1991). Os autores avaliaram citogeneticamente células do tumor, que apresentaram células com hiperdiploidia e hipodiploidia, aumento no número de cromossomos metacêntricos, mudanças de configuração e células com perda de um 


\section{Discussão}

cromossomo X. Estas informações autenticam os resultados originados desta dissertação.

Outros estudos foram realizados, como em casos de carcinomas mamários, onde análises de metáfases envolvendo coloração convencional revelaram casos de hipodiploidia, hiperdiploidia e tetraploidia cromossômicas (OWEN et al., 1977, 1981; ELSE et al., 1982; NORVALL et al. 1984; WOLFE et al., 1986).

Dois casos de osteossarcoma canino foram analisados citogeneticamente e revelaram alterações numéricas e estruturais com diversas fusões cêntricas identificadas nos cromossomos 1/3, 1/30 e 2/19, 3/19, 12/18, 13/17 (MAYR e ESCHBORN, 1991).

Mayr e colaboradores (1990) caracterizaram citogeneticamente um hemangiopericitoma canino, que apresentou número reduzido de cromossomos $(2 n=74)$, além de serem observadas alterações estruturais como deleções e fusões cêntricas envolvendo os cromossomos 5/6,5/14, 7/15 e 9/17, além de uma deleção no cromossomo 1.

A avaliação citogenética de tumores mamários constatou trissomia do cromossomo 1 em $20 \%$ das metáfases estudadas e monossomia do $\mathrm{X}$ juntamente à trissomia do 1 em 30\% das células em metáfase (MAYR et al., 1991).

Em 1992, Mayr e Kramberger-Kaplan analisaram citogeneticamente sarcomas mamários caninos e verificaram que $60 \%$ das metáfases observadas apresentaram cariótipo normal, e no restante, alterações estruturais e numéricas.

Em 1994, Mayr analisou quatro tumores sólidos em cães e constatou alterações estruturais e numéricas na composição do cariótipo desses animais, com cromossomos metacêntricos, fusões cêntricas e translocação.

Através de análise citogenética em osteossarcomas caninos, Mayr et al. (1991) detectaram alterações numéricas e estruturais em todas as metáfases observadas. Ocorreram fusões cêntricas $1 / 3,1 / 30,2 / 9$, além de contagem cromossômica de 65 a 67 . Todas as células apresentaram fusões cêntricas $3 / 19$, 3/?, 12/18 e 13/17. 


\section{Discussão}

A análise citogenética de um caso de melanoma maligno canino apresentou metade das metáfases analisadas com cariótipo canino normal $(2 n=78)$, sem detecção de alterações. Entretanto, as outras metáfases observadas apresentaram contagem de 79 a 81 cromossomos. Nessas células hiperdiplóides, foram observadas fusões cêntricas, parcialmente identificadas como 6/?, 10/? e 11/? (MAYR et al., 1992).

Estudos básicos relacionados à oncologia canina se mostram atrativos devido à grande procura por novos métodos diagnósticos e terapêuticos na medicina veterinária. Neste sentido, as técnicas citogenéticas apresentam um grande potencial, pois permitem o amplo conhecimento do comportamento e biologia tumoral. Assim, é possível compreender os mecanismos que acarretam as alterações genéticas durante o processo carcinogênico, e no futuro, serão úteis como uma importante ferramenta para avaliação do prognóstico dos animais portadores de neoplasias. 


\section{CONCLUSÕES}

- Não foram observadas alterações numéricas nas metáfases provenientes de linfócitos periféricos.

- Houve ocorrência de alterações numéricas e estruturais observadas nas metáfases de células dos mastocitomas.

- Foram detectadas alterações cromossômicas numéricas e estruturais nas metáfases mitóticas originadas de tecidos tumorais.

- As técnicas de colorações de banda C e G proporcionaram melhor análise das metáfases.

- As alterações estruturais podem estar associadas ao grau de malignidade dos tumores como conseqüência de tentativa de reparação dos erros genéticos causados pela descontrolada divisão celular decorrente da existência desse tumor. 


\section{REFERÊNCIAS}

ARMITAGE, P.; DOLL, R. The age distribution of cancer and a multi-stage theory of carcinogenesis. Britsh Journal of Cancer, v.8, n.1, 1954.

CARROLL, S. M.; GAUDRAY, P.; DE ROSE, M. L.; EMERY, J. F.; MEINKOTH, J. L.; NAKKIM, E.; SUBLER, M.; VON HOFF, D. D.; Characterization of an episome produced in hamster cells that amplify a transfected CAD gene at high frequency: functional evidence for a mammalian replication origin. Molecular Cell Biology. v 7 , n. 5, p.1740-50, 1987.

CARROLL, S. M.; DE ROSE, M. L.; KOLMAN, J. L.; NONET, G. H.; KELLY, R. E.; WAHL, M. Localization of a bidirectional DNA replication origin in the native locus and in episomally amplified murine adenosine deaminase loci. Molecular Cell Biology. n. 13, v. 5, p. 2971-81, 1993.

CHIARELLI, B. The chromosome complement of Nasalis larvatus. Experientia. v. 22, n. 12, p.797, 1966.

COHEN, D. The transmissible venereal tumor of the dog- a naturally occurring allograft? A review. In: WEISS, D. W. Ed. Imunological parameters of host-tumor relationships. New York: Academic, v.5, p.14-19, 1978.

COTRAN, R. S.; KUMAR, V.; ROBBINS, S. L. Neoplasia. In: Robbins pathologic basis of disease. 4. ed. Philadelphia: W. B. Saunders, 1989. p. 239-305. 


\section{Referências}

De VINNEY, R. GOLD, W.M. Establishment of two dog mastocytoma cell lines in continous culture. American journal of respiratory cell and molecular biology, v. 3, n. 3, p.413-420, 1990.

ELSE, R. W.; NORVAL, M.; NEILL, W. A. The characteristics of a canine mammary carcinoma cell line, REM 134. Britsh Journal of Cancer. V.46, v. 4, p.675-81, 1982.

FARBER, E. The multistep nature of cancer development. Cancer Research, Baltimore, v. 44, p. 4217-4223, 1984.

FARBER, E.; SARMA, D. S. R. Biology of disease. Hepatocarcinogenesis: a dynamic cellular perspective. Laboratory Investigation, New York, v. 56, n. 1, p. 4-22, 1987.

FORD, C. F.; HAMERTON, J. L. A colchicin hypotonic citrate squash sequence for mammalian chromosome. Stain Thechnology. v. 5, n. 31, p. 247-251. 1956.

FUJINAGA, T.; YAMASHITA, M.; YOSHIDA, M. C.; MIZUNO, S.; OKAMOTO, Y.; TAJIMA, M.; OTOMO, K. Chromosome analysis of canine transmissible sarcoma cells. Zentralblatt für Veterinärmedizin. Reihe C: Anatomie, Histologie, Embryologie. v. 36, n. 7, p. 481-489, 1989.

GAUBATZ, J. W. Extrachromosomal circular DNAs and genomic sequence plasticity in eukaryotic cells. Mutation Research. v. 237n. 5-6, p. 271-292, 1990.

GOLD, W. M. Isolated canine mastocytoma cells: porpagtion and characterizations of two cell lines. American Journal Physiology. 1986.

GOLDSCHMIDT, M. H.; SHOFER, F.S. Skin tumors of the dog and cat. $1^{\text {a }}$ ed Oxford: Pergamon Press, 1992. 316p.

GRAHAN, J. C.; O’KEEFE, D. A. Soft Sarcomas and Mast cell tumors. In: Birchard, S. J., Scherding, R. G. Saunders Manual of Small Animal Practice, Philadelphia: W. B. Saunders, 1994, 200:206. 


\section{Referências}

GRAHAN, J. C., O'KEEFE, D. A.: Sarcomas de tecido mole e mastocitomas. In: BICHARDS, S.J.; SHERDING, R. G. Manual saunders: Clínica de pequenos animais 1 ed. Roca: São Paulo, 1998. p.91-100.

GROSS, L. T.; IHRHE, P. J.; WALDER, E. J. Veterinary dermatopathology: a macroscopic and microscopic evaluation of canine and felines skin disease. St. Louis: Mosby, 1992. 519p.

Guerra, M. Introdução à Citogenética Geral. Ed. Guanabara Koogan: Rio de Janeiro-RJ. 142p. 1988).

GUERRA, M., SOUZA, M. J. Como observar cromossomos: um guia de técnicas em citogenética vegetal, animal e humana. Ed. Guanabara Koogan: Rio de Janeiro-RJ p. 89, 2002.

GRAPHODATSKY, A. S.; BEKLEMISHEVA, V. R.; DOLF, G. High-resolution GTGbanding patterns of dog and silver fox chromosomes: description and comparative analysis. Cytogenetics and cell genetics. v. 69, n. 3-4, p. 226-231,1995.

HARE, P. J. Malignant haemangio-endothelioma. Proceedings of the Royal Society of Medicine. n. 58, p. 423, 1965.

HOLLIDAY, R. Chromossome error propagation and cancer. Trends in genetics. n. 5, p.4245, 1989.

Howard-Peebles PN, Pryor JC. The R-banding pattern of the canine karyotype. The Journal of heredity. v. 71, n. 5, p. 361-2, 1980.

HOWELL, W. M.; BLACK, D. A. Controlled silver-staining of nucleolus organizer regions with protective colloidal developer: a $1^{\text {st }}$ step method. Experientia. n. 36, p. 1014-1015, 1980. 


\section{Referências}

HSU, T. C.; MOORHEAD, P. S. Chromosome anomalies in human neoplasms with special reference to the mechanisms of polyploidization and aneuploidization in the HeLa strain.

Annals of the New York Academy of Sciences. v.63, n. 6, p. 1083-1094, 1956.

HUEPER, W.C. Enviromental carcinogenesis in man and animals. Annals of the New York Academy of Sciences. v. 108 p. 963-970, 1963.

ISCN, An International System for human cytogenetic nomenclature (Mitelman F, eds). Basel: S. Karrer. 1995

JANEWAY JR, C. A.; TRAVERS, P.; WALPORT, M.; SHLOMCHIK, M. J. Resposta immune humoral. In: Imunobiologia: o sistema imune na saúde e na doença. 5. ed São Paulo: Artmed. 2002. p. 399-400.

LANGFORD, C. F.; FISCHER, P. E.; BINNS, M. M.; HOLMES, N. G.; CARTER, N. P.; Chromosome-specific paints from a high high-resolution flow karyotipe of the dog. Chromosome Research. n. 4, p. 115-123, 1996.

LAZARUS, S. C. Role of inflammation and inflammatory mediators in airways disease. The American Journal of Medicine v. 81, n. 5a , p. 2-7, 1986.

LOWER, K. Neoplasias Malignas e Benignas. In: MEDLEAU, L.; HNILICA, K. A.

Dermatologia de Pequenos Animais: Atlas Colorido e Guia Terapêutico. 1.ed. São Paulo: Roca, 2003. 353 p.

KITCHELL, B. E. Cancer therapy for geriatric dogs and cats. Journal of the American Animal Hospital Association, v.29, p.41-8, 1993.

KRAEGEL S. A., PAZZI KA, MADEWELL BR. Sequence analysis of canine p53 in the region of exons 3-8. Cancer letters. v.92, n. 2, p. 181-186, 1995. 


\section{Referências}

LEMARIÉ, R. J., LEMARIÉ, S. L., HEDLUND, C. S. Mast cell tumors: clinical management. Compendium on Continuing Education for the practicing Veterinarian, v9, n.9, p. 10851101, 1995.

LOWER, K. Neoplasias Malignas e Benignas. In: MEDLEAU, L.; HNILICA,

K. A. Dermatologia de Pequenos Animais: Atlas Colorido e Guia Terapêutico.

1.ed. São Paulo: Roca, 2003. 353 p.

MACY, D.W.; MACEWEN, E.G. Mast cell tumors. In: WITHROW S.J.; MACEWEN, E.G (Ed.). Veterinary oncology. Philadelphia: J.B. Lippincott, 1986. p.156-165.

MADEWELL, B.R.; THEILEN, G. H.: Mast cell and melanocytic neoplasms. In: THEILEN, G. H.; MADEWELL, B. R.: Veterinary Cancer Medicine, 2a edição, Philadelphia: Lea \& Febiger, 1987, 310-4.

Banding analysis of the somatic chromosomes of the domestic dog (Canis familiaris). Manolache M, Ross WM, Schmid M. Canadian journal of genetics and cytology. Journal canadien de génétique et de cytologie. v. 18, n. 3, p. 513-8, 1976.

MAYR, B. Citogenetic analysis of four solid tumours in dogs. Research in Veterinary Science. 57, 88-95. 1994.

MAYR, B.; ESCHBORN, U. Characterization of complex karyotype in two canine bone tumours. Research in Veterinary Science. n. 51, p.341-3, 1991.

MAYR, B.; GILLI, H.; SCHLEGER, W.; REIFINGER, M; BURTSCHER, H. Cytogenetic characterization of mammary tumours in two domestic dogs. Journal of veterinary medical education. n. 38, p. 141-7, 1991.

MAYR, B.; KRAMBERGER-KAPLAN, E. Analysis of complex alterations in three canine mammary sarcomas. Research in Veterinary Science. n. 53, p. 205-11, 1992. 


\section{Referências}

MAYR, B., REIFINGER, M., BREM, G., FEIL, C., SCHLEGER, W. Cytogenetic, ras, and p53: srudies in cases of canine neoplasms (hemangiopericytoma, mastocytoma, histiocytoma, chloroma). The American Genetic Association. n. 90, p. 124-128, 1999.

MAYR, B.; SWIDERSKY, W.; SCHLEGER, W.; REIFINGER, M. Cytogenetic characterization of canine haemangiopericytoma. The British veterinary journal. n.146, p. 260, 1990.

METCALFE, D. D., BARAM, D., MEKORI, Y. A. Mast cells. Physiological reviews. v. 77, n. 4, p. 1033-1079, 1997

MILLER, D. M. The ocurrence of mast cell tumors in young Shar- Peis.

Journal of veterinary diagnostic investigation. v.7, p.360- 363, 1995.

MISDORP, W. Mast cells and canine mast cell tumours. A review. The Veterinary quarterly. v. 26, n. 4, p. 156-69, 2004.

MITELMAN, F.; JOHANSSON, B.; MERTENS, F. (eds): Mitelman Database of chromosome aberrations in cancer.

(http://cgap.nci.nih.gov/Chromosomes/Mitelman) (2007).

MOORE, W. JR.; LAMBERT, P. D. The chromosomes of the beagle dog. The Journal of heredity. n. 54, p.273-276,1963.

MURPHY, G. F.; SELLHEYER, K.; MIHM Jr, M. C. Doenças dos sistemas de órgãos. In: KUMAR, V.; ABBAS, A. K.; FAUSTO, N. Patologia - bases patológicas das doenças. 7. ed Rio de Janeiro: Elsevier. 2005. p.1306-1308. 


\section{Referências}

WOLFE, L. G.; SMITH, B. B.; TOIVIO-KINNUCAN, M. A.; SARTIN, E. A.; KWAPIEN, R. P.; HENDERSON, R. A.; BARNES, S. Biologic properties of cell lines derived from canine mammary carcinomas. Journal of the National Cancer Institute. v. 77, n. 3, p. 783-792, 1986.

O'BRIEN, M. G.; WHITHRON, S. J. Oncologia cirúrgica. In: ETTINGER, S. J.; FELDMAN, E.C. Tratado de medicina interna veterinária. 4. ed São Paulo: Manole, 1997. p. 723-32.

OGILVIE, G.; MICHENER,K. Care beyond cure: mast cell tumour-New tricks for the new millennium. In: Midwest veterinary conference, 116, Columbus, 2000. Procedings. Columbus, 2000. v2, p. 55-8.

OGILVIE, G. K.; MOORE, A. S. Mast cell tumors in Dogs. In:. Managing the Veterinary Cancer Patient: a practice manual. 1.ed. Trenton: Vet. Learning Systems Company, 1995. p.493 -510 .

O'KEEFE, D. A. Sarcomas de tecido mole e mastocitomas In: Clínica de pequenos animais, manual Saunders, 2003 p. $241-4$.

OWEN, L. N,; MORGAN, D. R,; BOSTOCK, D. E,; FLEMANS, R. J. Tissue culture and transplantation studies on canine mammary carcinoma. European journal of cancer. v. 13, n. 2, p. 1445-9, 1977.

PAINTER, T. S. CHROMOSOME NUMBERS IN MAMMALS. Science. v. 17, n. 61, p. 423-424, 1925.

PATNAIK, A. K.; EHLER, W.J.; MACEWEN, E. G.: Canine cutaneous mast cell tumor: morphologic grading and survival time in 83 dogs, Veterinary Pathology, v. 21, n. 5; p. 469-474, 1984. 


\section{Referências}

PITOT, H. C.; DRAGAN, Y. P. Facts and theories concerning the mechanisms of carcinogenesis. The FASEB journal. v. 5, n. 9, p. 2280-2286, 1991.

POULSEN, B. S.; SHIBASAKI, Y.; IKEUCHI, T.; RØNNE, M. Banding studies in Canis familiaris. Replication patterns in karyotypes from lymphocyte cultures. Cytobios. v. 62, n. 250-251, p. 161-165, 1990.

PULLEY, L.T.; STANNARD, A.A. Tumours of the skin and soft tissues. In: MOULTON, J.E. Tumours In Domestic Animals. Berkeley: California Press, 1990. p.23-87.

REDDY, K. S. Double minutes (dmin) and homogeneously staining regions (hsr) in myeloid disorders: a new case suggesting that dmin forms hsr in vivo. Cytogenetic Genome Research. n. 119, p. 53-59, 2007.

N. REIMANN, S. BARTNITZKE, I. NOLTE, AND J.BULLERDIEK. Working with canine chromosomes: current recommendations for karyotype description. The American Genetic Association. n. 90, p. 31-34, 1999.

REGUERA, M. J., RABANAL, R. M., PUIGDEMONT, A., FERRER, L. Canine mast cell tumors express stem cell factor receptor. The American Journal of dermatopathology. v. 22, n. 1, p. 49-54, 2000.

SEABRIGHT, M. A rapid banding technique for humam chromosomes. Lancet. 2: $971,1971$.

SCOTT, W. D.; MILLER, H. W.; GRIFFIN, E. C. Tumores neoplásicos e não neoplásicos. In: MILLER e KIRK. Dermatologia de Pequenos Animais. 5. ed. Rio de Janeiro: Interlivros, 1996. Tradução de: Small Animal Dermatology. 


\section{Referências}

SELDEN, J. R.; MOORHEAD, P. S.; OEHLERT, M. L.; PATTERSON, D. F. The Giemsa banding pattern of the canine karyotype. Cytogenetics and cell genetics. v.15, n. 6 , p. 380-388, 1975.

SELYE,H.: Mast Cell - Review, 1a Edição, Washington: Butterworths Inc., 1965, p. $275-78$.

SIMÕES, J. P. C. Canine mast cell tumors: a comparison of staining techniques. Journal of Veterinary Diagnostic Investigation, v. 06. p. 458 - 65, 1994.

SIMPSON, A. M.; LUDWIG, L. L.; NEWMAN, S. J. et al. Evaluation of surgical margins required for complete excision of cutaneous mast cell tumors in

Dogs. Journal of the American Veterinary Medical Association. n. 224, p. 236 240, 2004.

SOLOMON, E.; BORROW, J.; GODDARD, A. D. Chromosome aberrations and cancer. Cancer Genetic and Cytogenetic. v. 8, n. 5035, p. 1153, 1991.

SOTER, N. A. Mastocytosis and the skin. Hematology/Oncology Clinics of Noth America, v. 14, n. 3, p.537-555, 2000.

SOUZA, T. M.; FIGUERA, R. A.; IRIGOYEN, L. F.; BARROS, C. S. Estudo retrospectivo de 761 tumores cutâneos em cães. Ciência Rural. v.36, n.2, p. 555 560, 2006.

STANNARD, A. A.; PULLEY, L. T. Tumors of the skin and soft tissues. In: MOULTON, J. E. Tumors in domestic Animals. 3. ed. Berkeley: University of Califórnia, 1990. cap. 2, p. 23 - 87.

STONE, D.; JACKY, P. B.; PRIEUR, D. J.. Cytogenetic evaluation of four canine mast cell tumours. Cancer Genetic and Cytogenetic. n. 53, p. 105-112, 1991. 


\section{Referências}

SUMNER, A. T. A simple technique for demonstrating centromeric heterochromatin .

Experimental cell research. n. 75, p. 304-306, 1972.

SWITONSKI, M.; REIMANN, N.; BOSMA, A. A.; LON, S.; BARTNITZKE, S.;

PIENKOWSKA, A.; MORENO-MILAN, M. M.; FISCHER, P. Report on the progress of the standardization of the G-banded canine karyotipe. Chromosome Research. $\mathrm{n}$. 4, p. 306-309, 1996.

VAIL, D. M.: Mast cell tumors. In: WITHROW S. J.; MACEWEN, E. G.: Small Animal Clinical Oncology, 2a ed. Philadelphia PA: WB Saunders, 1996. p. 192:210.

WINKLER, S., MURUA ESCOBAR, H., REIMANN-BERG, N., BULLERDIEK, J., NOLTE, I. Cytogenetic investigations in four canine lymphomas. Anticancer Reserach. v. 25, n. 6B, p. 3995-3998, 2005.

WHITE, M. J. D. Os Cromossomos. Companhia Editora Nacional, São Paulo - SP. 196p. 1977

ZAPPULLA, J. P., AROCK, M., MARS, L. T., LIBLAU, R. S. Mast cells: new targets for multiple sclerosis therapy? Journal of neuroimmunology. v.131, n. 1-2, p. 1520, 2002.

ZEMKE, D.; YAMINI, B.; YUZBASIYAN-GURKAN, V. Mutations in the Juxtamembrane Domain of C-KIT are Associated with Higher Grade Mast Cell Tumors in Dogs. Vetherinary. Pathology. v.39, p. 529 -535, 2002. 
WAHL, G. M. The importance of circular DNA in mammalian gene amplification. Cancer Research. v. 49, n. 6, p. 1333-1340, 1989.

WANG HC, FEDOROFF S. Banding in human chromosomes treated with trypsin. Nature: New biology. v. 235, n. 54, p. 52-54, 1972. 